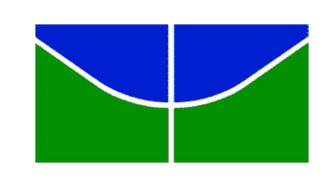

UNIVERSIDADE DE BRASÍLIA - UNB

INSTITUTO DE RELAÇÕES INTERNACIONAIS (IREL)

PROGRAMA DE PÓS-GRADUAÇÃ̃o EM RELAÇÕES INTERNACIONAIS

(PPGRI)

\title{
POLÍTICA EXTERNA E POLÍTICA MIGRATÓRIA NO BRASIL: CONVERGÊNCIAS E DISTANCIAMENTOS (1995-2010)
}

GABRIEL FELIPE DA FONSECA DIZNER

Brasília - DF

2015 


\section{POLÍTICA EXTERNA E POLÍTICA MIGRATÓRIA NO BRASIL: CONVERGÊNCIAS E DISTANCIAMENTOS (1995-2010)}

Dissertação apresentada ao Programa de PósGraduação do Instituto de Relações Internacionais da Universidade de Brasília como requisito parcial para obtenção do título de Mestre em Relações Internacionais.

Orientador: Prof. Dr. Antonio Jorge Ramalho da Rocha

Brasília - DF 


\title{
POLÍTICA EXTERNA E POLÍTICA MIGRATÓRIA NO BRASIL: CONVERGÊNCIAS E DISTANCIAMENTOS (1995-2010)
}

Comissão Examinadora:

\author{
Prof. Dr. Antonio Jorge Ramalho da Rocha \\ Universidade de Brasília - IREL/UnB \\ Orientador
}

Prof. Dr. Antonio Carlos Lessa

Universidade de Brasília - IREL/UnB

Examinador

Prof. Dr. Leonardo Cavalcanti da Silva

Universidade de Brasília - CEPPAC/UnB

Examinador

Prof. Dr. Eitii Sato

Universidade de Brasília - IREL/UnB

Examinador (suplente) 
A todos os descendentes de migrantes

(porque "esses estrangeiros!" também já foram ou são

seus avós,

seus pais,

seus irmãos). 


\section{AGRADECIMENTOS}

Ao Prof. Dr. Antonio Jorge Ramalho da Rocha, por seu exemplo como pesquisador, docente e profissional e por aceitar me conduzir nessa caminhada em busca do conhecimento.

Ao Prof. Dr. Antonio Carlos Lessa, pelos comentários e observações na defesa do projeto e por aceitar participar da Comissão Examinadora.

Ao Prof. Dr. Leonardo Cavalcanti, por compartilhar tantos conhecimentos e estimular debates interessantes que instigaram minha curiosidade sobre o tema das migrações internacionais.

Ao Prof. Dr. Eitii Sato, por participar como suplente na Comissão Examinadora e ter fornecido contribuições para o aprimoramento deste estudo.

A todos os professores do Programa de Pós-Graduação em Relações Internacionais, referências pela produção acadêmica e exemplo de dedicação ao ensino e à pesquisa nas Relações Internacionais no Brasil.

Aos servidores da Universidade de Brasília, em especial à Odalva, ao Anderson e à Vanessa, pela gentileza e presteza na solução de questões administrativas.

Aos colegas da pós-graduação, em especial a Átila Rabelo, Rodrigo Mota, Maria Helena Notari, Thais Menezes e Patrícia Nabuco Martuscelli pela convivência enriquecedora, debates inteligentes, bom humor e pelo companheirismo ao longo do curso.

Aos meus chefes e colegas do Ministério do Planejamento, Orçamento e Gestão, em especial, Antonio Augusto Ignacio Amaral, Christiano Perez de Resende e Rafael de Sousa Moreira, que compreenderam a importância desta formação para mim em termos pessoais e profissionais.

Aos participantes da pesquisa, que gentilmente me receberam e relataram suas percepções acerca das migrações internacionais, essenciais para a realização deste estudo.

Aos amigos Rafael Tavares Schleicher e Ricardo José Lustosa Leal pela primeira leitura do projeto e pelas contribuições ao texto. Agradeço também a Jana Petaccia de Macedo e Delano Cerqueira pelo apoio durante a realização desta pesquisa.

Às amigas Aline Mac Cord, Giovanna Lucio, Valéria Vogado, Thais Mesquita e ao amigo Marco Candia, pelos momentos de descontração que tornaram a caminhada mais leve.

À minha sogra, Fusae Mizushima, por me receber com carinho na família nipo-brasileira na qual eu não me sinto gaijin.

A meu pai, Sergio Jorge Dizner (Tony Osanah), o primeiro imigrante que conheci, pelo que me ensinou sobre o valor de ser livre e ousar cruzar fronteiras.

À minha mãe, Maria Terezinha Fonseca (Tereza Teller), por me incentivar a jamais parar de estudar e a prosseguir em busca dos meus sonhos.

À minha querida Mary, agradeço todo amor, estímulo, paciência e apoio, sobretudo na realização do mestrado, e também por me ajudar a manter o foco. Sua presença melhora tudo à minha volta!

A Deus, pelo seu Infinito Amor, e ao meu Anjo, que sempre me rege, guarda, governa e ilumina. 
O suor fecunda o solo e a semente não pergunta: Brasileiro ou imigrante? Só o fruto é importante.

Não me sinta forasteiro.

Não me invente geografias.

Sou tua raça, sou teu povo, Sou teu irmão no dia-a-dia.

(Fruto do Suor, de Tony Osanah e Enrique Bergen) 


\section{RESUMO}

O objetivo desta dissertação é analisar a política externa dos governos Fernando Henrique Cardoso (1995-2002) e Luiz Inácio Lula da Silva (2003-2010) e seus reflexos sobre a evolução da política migratória brasileira, a partir da descrição dos processos de construção da estratégia de inserção internacional do Brasil. A hipótese defendida no trabalho é de que é possível identificar influências da política externa na política migratória no período. O cotejo entre os discursos e posições oficiais e as leis e estatísticas sobre migrações permite mapear convergências entre as posições assumidas pelo Brasil nos foros internacionais em matéria de promoção dos direitos humanos dos migrantes, mas também distanciamentos, situações em que as práticas contradizem os discursos. Argumenta-se que, no caso da emigração, essa conexão se materializa por meio da extensão de serviços consulares e previdenciários aos nacionais, que atende ao duplo objetivo de contribuir para a valorização das comunidades brasileiras no exterior e, portanto, para a imagem do Brasil, e de reforçar os laços de nacionalidade e cidadania; quanto à imigração, contudo, resistências internas do governo e da sociedade ainda impedem uma atualização das normas e das políticas públicas para os migrantes. Esta dissertação conclui pela necessidade de maior discussão da agenda das migrações (emigração e imigração), a fim de que possam ser estabelecidos parâmetros que definam que tipo de política melhor atende aos interesses nacionais e de que o Brasil possa avançar nesse tema em consonância com seu histórico de receptor de migrantes e seu discurso de defesa dos direitos humanos.

Palavras-chave: Brasil; Política Externa; Política Migratória; Fluxos Migratórios; Direitos Humanos. 


\begin{abstract}
The aim of this work is to analyze the Brazilian foreign policy during the mandates of Presidents Fernando Henrique Cardoso (1995-2002) and Luiz Inácio Lula da Silva (2003-2010), and its impact on the evolution of Brazilian migration policy, from the description of the strategy building process international insertion of Brazil. The hypothesis put forward in the paper is that it is possible to identify influences of foreign policy in migration policy in the period. By comparing speeches and official positions with laws and statistics on migration it is possible to map convergences between the Brazilian positions in international forums for the promotion of human rights of migrants, but also moments when practices contradict the speeches. It is argued that, in the case of emigration, this connection is materialized through the extension of social security and consular services to nationals, which serves the dual purpose of contributing to the appreciation of the Brazilian communities abroad, and, thus, to Brazil's image itself, and strengthening ties of nationality and citizenship; as for immigration, however, stiff resistance by government and society still prevent an update of norms and public policies for migrants. The text concludes with the idea that an improved migration agenda of discussion regarding both emigration and immigration is needed, so that parameters may be established that define which migration policy best serves national interest, so that Brazil can move forward regarding this issue in accordance with its history of migration and its official discourse in the defense of Human Rights.
\end{abstract}

Keywords: Brazil; Foreign Policy; Migration Policy; Migratory Flows; Human Rights. 


\section{LISTA DE GRÁFICOS}

Gráfico 1. Reservas Internacionais (1995-2002) - em US\$ bilhões 14

Gráfico 2. Variações da Taxa Básica de Juros - SELIC (1996-2002) 14

Gráfico 3. Ingressos de Investimento Estrangeiro Direto (1995-2002) - em US\$ bilhões 15

Gráfico 4. Ingressos de Investimento Estrangeiro Direto (2003-2010) - em US\$ bilhões 22

Gráfico 5. Reservas Internacionais (2003-2010) - em US\$ bilhões 22

Gráfico 6. Variações da Taxa Básica de Juros - SELIC (2003-2010) 23

Gráfico 7. Remessas para o Brasil de 1995 a 2012 (fontes oficiais) - em US\$ milhões 78

Gráfico 8. Volume de remessas recebidas no Brasil de 2001 a 2007 (estimativas) - em US\$ milhões 79

Gráfico 9. Refugiados no Brasil - 1995 a 2014

Gráfico 10. Evolução da ratificação de instrumentos legais relacionados à migração internacional $\quad 101$

\section{LISTA DE TABELAS}

Tabela 1. Gastos com cooperação técnica (1995-2010) - em R \$ mil 36

Tabela 2. Gastos com a Cooperação Internacional (2005-2010) - em R\$ mil 37

Tabela 3. Relação entre o quantitativo de estrangeiros residentes e a população total - em milhares 51

Tabela 4. Imigrantes - principais países de nacionalidade - em milhares 52

Tabela 5. Estimativas de brasileiros residentes no exterior - em milhares $\quad 54$

Tabela 6. Remessas para o Brasil de 2010 a 2012 (fontes oficiais) - em US\$ milhões 78

Tabela 7. Instrumentos internacionais relativos às migrações internacionais ratificados pelo Brasil 101 


\section{LISTA DE SIGLAS E ABREVIATURAS}

\begin{tabular}{|c|c|}
\hline $\mathrm{ABC}$ & Agência Brasileira de Cooperação/MRE \\
\hline ACNUR & Alto-Comissariado das Nações Unidas para Refugiados \\
\hline AGNU & Assembleia-Geral das Nações Unidas \\
\hline ANVISA & Agência Nacional de Vigilância Sanitária \\
\hline BACEN & Banco Central do Brasil \\
\hline BID & Banco Interamericano de Desenvolvimento \\
\hline CASA & Comunidade Sul-Americana de Nações \\
\hline $\mathrm{CBM}$ & Conferências Brasileiros no Mundo \\
\hline CEDEPLAR & $\begin{array}{l}\text { Centro de Desenvolvimento e Planejamento } \\
\text { Regional/UFMG }\end{array}$ \\
\hline $\mathrm{CEF}$ & Caixa Econômica Federal \\
\hline CEPAL & Comissão Econômica para a América Latina \\
\hline $\mathrm{CF}$ & Constituição Federal \\
\hline CGEE & Centro de Gestão e Estudos Estratégicos \\
\hline CGIg & Coordenação-Geral de Imigração/MTE \\
\hline CGPI & Coordenação-Geral de Polícia de Imigração/DPF \\
\hline CNIg & Conselho Nacional de Imigração/MTE \\
\hline CNPD & Comissão Nacional de População e Desenvolvimento \\
\hline COPOM & Comitê de Política Monetária/BACEN \\
\hline CONARE & Comitê Nacional para Refugiados/MJ \\
\hline CPLP & Comunidade dos Países de Língua Portuguesa \\
\hline CPMI & Comissão Mista Parlamentar de Inquérito \\
\hline CRBE & Comunidades Brasileiras no Exterior \\
\hline CSM & Conferência Sul-Americana sobre Migrações \\
\hline CTBT & Comprehensive Nuclear-Test-Ban Treaty \\
\hline CTPD & Cooperação Técnica Prestada a Países em Desenvolvimento \\
\hline DEEST & Departamento de Estrangeiros/MJ \\
\hline DIJ & Departamento de Imigração e Assuntos Jurídicos/MRE \\
\hline DIM & Divisão de Imigração/MRE \\
\hline DPF & Departamento de Polícia Federal/MJ \\
\hline EBC & Empresa Brasileira de Comunicação \\
\hline EMBRAPA & Empresa Brasileira de Pesquisa Agropecuária \\
\hline FGTS & Fundo de Garantia por Tempo de Serviço \\
\hline FHC & Fernando Henrique Cardoso \\
\hline FIESP & Federação das Indústrias de São Paulo \\
\hline FUMIN & Fundo Multilateral de Investimentos/BID \\
\hline GATT & General Agreement on Tariffs and Trade \\
\hline IBAS & Índia-Brasil-África do Sul \\
\hline IBGE & Instituto Brasileiro de Geografia e Estatística \\
\hline IED & Investimento Estrangeiro Direto \\
\hline IMDH & Instituto Migrações e Direitos Humanos \\
\hline IMI & International Migration Institute/Oxford University \\
\hline IPEA & Instituto de Pesquisa Econômica Aplicada \\
\hline $\mathrm{IRBr}$ & Instituto Rio Branco/MRE \\
\hline MERCOSUL & Mercado Comum do Sul \\
\hline MINUSTAH & Missão das Nações Unidas para a Estabilização do Haiti \\
\hline MJ & Ministério da Justiça \\
\hline
\end{tabular}




$\begin{array}{ll}\text { MRE } & \text { Ministério das Relações Exteriores } \\ \text { MTE } & \text { Ministério do Trabalho e Emprego } \\ \text { NAB } & \text { Núcleo de Assistência a Brasileiros/MRE } \\ \text { NEPO } & \text { Núcleo de Estudos de População/Unicamp } \\ \text { NIATRE } & \text { Núcleo de Informação e Apoio aos Brasileiros Retornados } \\ & \text { do Exterior } \\ \text { OBMigra } & \text { Observatório das Migrações Internacionais/UnB } \\ \text { OCDE } & \text { Organização para a Cooperação e o Desenvolvimento } \\ & \text { Econômico } \\ \text { OEA } & \text { Organização dos Estados Americanos } \\ \text { OIM } & \text { Organização Internacional para as Migrações } \\ \text { OIT } & \text { Organização Internacional do Trabalho } \\ \text { OMC } & \text { Organização Mundial do Comércio } \\ \text { ONU } & \text { Organização das Nações Unidas } \\ \text { PALOP } & \text { Países Africanos de Língua Oficial Portuguesa } \\ \text { PEB } & \text { Política Externa Brasileira } \\ \text { PL } & \text { Projeto de Lei } \\ \text { PLS } & \text { Projeto de Lei do Senado } \\ \text { PNAD } & \text { Pesquisa Nacional por Amostra de Domicílios } \\ \text { PR } & \text { Presidência da República } \\ \text { PT } & \text { Partido dos Trabalhadores } \\ \text { RN } & \text { Resolução Normativa } \\ \text { SAE } & \text { Secretaria de Assuntos Estratégicos/PR } \\ \text { SELIC } & \text { Sistema Especial de Liquidação e de Custódia } \\ \text { SGEB } & \text { Subsecretaria-Geral das Comunidades Brasileiras no } \\ \text { TNP } & \text { Exterior/MRE } \\ \text { TSE } & \text { Tratado de Não Proliferação } \\ \text { UFMG } & \text { Tribunal Superior Eleitoral } \\ \text { UNASUL } & \text { Universidade Federal de Minas Gerais } \\ \text { UnB } & \text { União de Nações Sul-Americanas } \\ \text { UNCTAD } & \text { Universidade de Brasília } \\ \text { UNESCO } & \text { United Nations Conference on Trade and Development } \\ \text { UNICAMP } & \text { United Nations Educational, Scientific and Cultural } \\ \text { UNRWA } & \text { Organization } \\ & \text { Universidade Estadual de Campinas } \\ \text { Refugees in the Near East }\end{array}$




\section{SUMÁRIO}

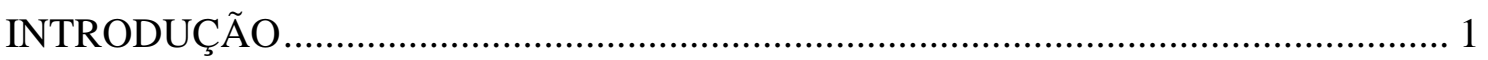

CAPÍTULO 1: A Política Externa dos Governos de Fernando Henrique Cardoso e Luiz

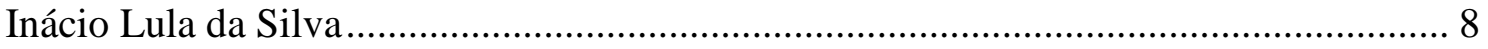

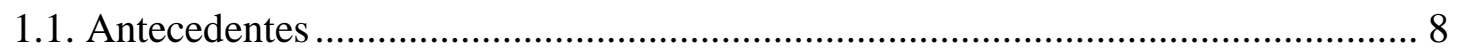

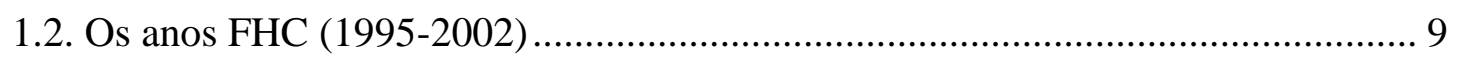

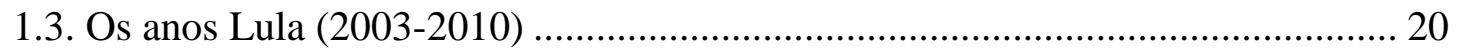

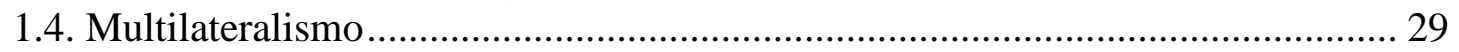

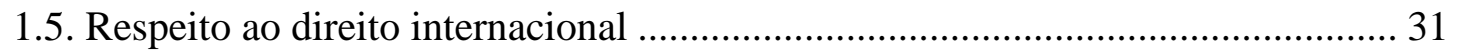

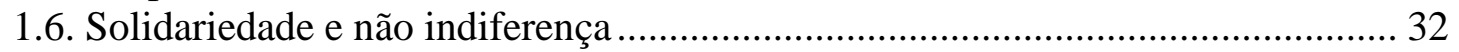

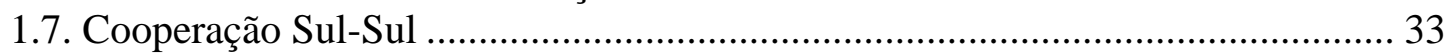

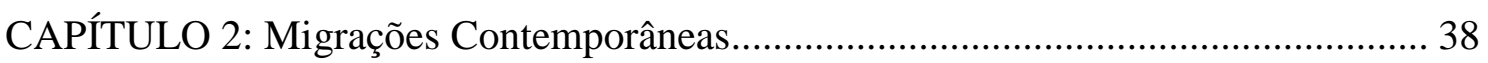

2.1. Teorias explicativas sobre as migrações internacionais ................................... 41

2.2. Breve histórico das migrações no Brasil........................................................... 49

2.3. Evolução da legislação migratória: manutenção de anacronismos....................... 56

2.4. Atuação dos órgãos de governo envolvidos em temas migratórios ...................... 63

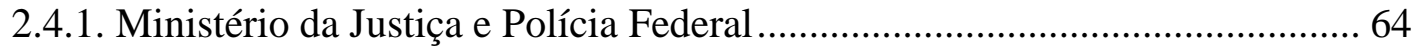

2.4.2. Ministério do Trabalho e Conselho Nacional de Imigração............................ 64

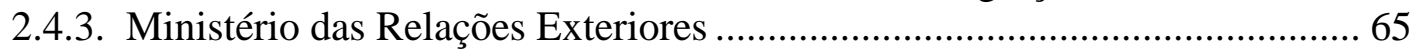

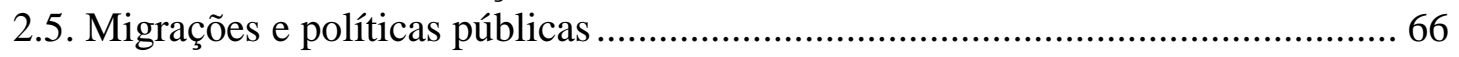

CAPÍTUlO 3: Pontos de contato entre a Política Externa e a Política Migratória........ 73

3.1. Principais convergências.................................................................................. 73

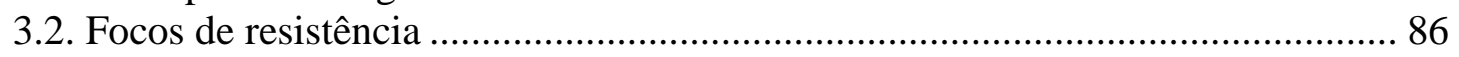

3.3. Articulação entre a política externa e a política migratória .................................. 91

CONCLUSÃO

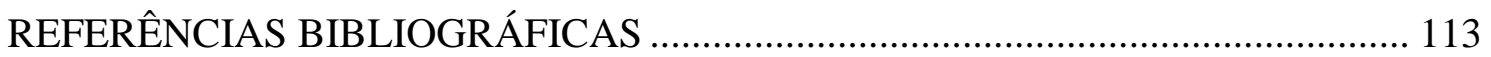

APÊNDICE A - Expansão da rede consular............................................................ 125

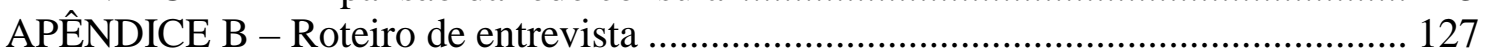

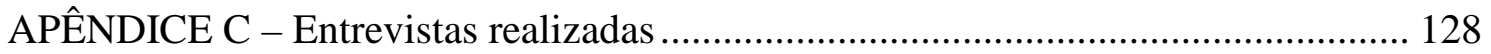

APÊNDICE D - Composição do Conselho Nacional de Imigração .............................. 129

APÊNDICE E - Excertos de Atas do Conselho Nacional de Imigração. ..................... 130

APÊNDICE F - Número de deportações de 1995 a 2010 - por nacionalidade ............ 131 


\section{Introdução}

Entre os anos de 1995 e 2010, a política externa brasileira caracterizou-se pela busca ativa por maior projeção internacional. A progressiva estabilização da economia, a partir do Plano Real, lançado em 1994, o bom momento por que passou o Brasil em termos comerciais e as ações governamentais voltadas à redução das desigualdades sociais colaboraram para aumentar a visibilidade do País no exterior. No esforço de expandir a inserção internacional do Brasil, os princípios de defesa dos direitos humanos, da solidariedade internacional e da não indiferença tiveram destaque no período em referência. Intensificaram-se as ações de cooperação internacional prestada a países em desenvolvimento, bem como as operações de ajuda humanitária e a participação em missões de paz sob a égide das Nações Unidas. Além disso, o Brasil ascendeu no grupo das 10 maiores economias do globo. A despeito da recente retração econômica e dos problemas enfrentados atualmente, a imagem do Brasil como país de oportunidades parece ter sido reforçada desde então.

Em paralelo, o fim da Guerra Fria e o fenômeno da globalização contribuíram para o aumento dos fluxos migratórios internacionais. A facilidade de locomoção e de circulação de informações entre os Estados alcançou níveis sem precedentes no final do século XX e início do XXI, resultado dos avanços tecnológicos dos meios de transporte e da informática. A esses movimentos se contrapõem ações dos Estados para estabelecer controles rígidos sobre a circulação de pessoas através das fronteiras nacionais. Os deslocamentos populacionais, voluntários ou forçados, representam desafios para a soberania dos Estados, envolvendo questões de segurança e de proteção aos direitos humanos dos migrantes.

Ao contrário de muitos países do Norte geopolítico, o Brasil não tem uma política orientada para prender e deportar imigrantes em massa. Além disso, os brasileiros também emigram em busca de melhores condições de vida no exterior. No período analisado, esses emigrantes passaram a contar, por determinação presidencial, com maior assistência do Ministério das Relações Exteriores. Essa população tem demandas específicas e constitui um público importante para o Estado, em função dos laços de cidadania e pelo expressivo volume de remessas financeiras enviadas anualmente ao Brasil. Além disso, a presença de comunidades brasileiras no exterior é 
tema importante das relações bilaterais entre o Brasil e os países com os maiores contingentes, como Estados Unidos, Paraguai, Japão, Portugal e Espanha.

Em outra vertente, as populações estrangeiras que buscam o Brasil para residir e trabalhar encontram uma política migratória fragmentada, baseada em uma legislação anacrônica, que vem sofrendo atualizações pontuais como resultado do esforço de construção coletiva entre os órgãos governamentais que tratam do tema das migrações internacionais. Além disso, no campo dos direitos humanos, foram assumidas posições favoráveis à migração e à dignidade humana do trabalhador migrante em foros e organizações internacionais que tratam do tema.

Desde o ano 2000, o Brasil participa da Conferência Sul-Americana sobre Migrações (CSM), que reúne anualmente as doze nações do subcontinente para o intercâmbio de ideias e a coordenação de políticas migratórias. A primeira CSM foi realizada em Buenos Aires, e sua declaração final reconhece a necessidade de diálogo multilateral para coordenar iniciativas e programas de promoção e formulação de políticas para as migrações internacionais e sua relação com o desenvolvimento e a integração regional. O Brasil, que sediou a XI CSM em Brasília pela primeira vez em 2011, tem participado regularmente das Conferências com delegação composta por representantes dos Ministérios da Justiça, do Trabalho e das Relações Exteriores. Em 2004, o país assinou a Convenção Internacional sobre a Proteção dos Direitos de Todos os Trabalhadores Migrantes e Membros de suas Famílias (ainda pendente de ratificação), adotada pela Resolução 45/158 da Assembleia-Geral das Nações Unidas, de 18 de dezembro de 1990. Por fim, cabe destacar a iniciativa do Brasil, em 2004, de aderir à Organização Mundial para as Migrações ${ }^{1}$, um dos principais foros multilaterais de discussão sobre o tema.

A literatura de Relações Internacionais ainda mantém foco principal nos temas relativos a poder e segurança (high politics ${ }^{2}$ ), classificando as migrações internacionais na categoria de "outros temas" (low politcs ${ }^{3}$ ), como meio ambiente e questões de gênero. Atualmente, a distinção entre high e low politics demonstra ser inadequada para

\footnotetext{
${ }^{1}$ Sediada em Genebra, a OIM é uma organização governamental que não integra o sistema ONU. Composta por 157 Estados membros e 10 observadores, foi fundada em 1951, e tem por objetivo promover estudos e ações de cooperação com governos e organizações da sociedade civil sobre temas migratórios e oferecer assistência humanitária aos migrantes.

${ }^{2}$ Tradicionalmente associado ao paradigma realista relações internacionais, o termo high politics refere-se aos temas de segurança e de defesa nacional, cujo foco é a soberania do Estado no sistema anárquico internacional, a qual, em última análise, é a garantia de sua própria sobrevivência.

${ }^{3}$ Low politics, no paradigma realista, refere-se às políticas que não se ocupam diretamente da necessidade de sobrevivência do Estado, envolvendo aspectos econômicos, comerciais e culturais.
} 
compreender a realidade, pois os Estados podem securitizar temas que não são típicos da área de segurança, como as migrações internacionais, em um esforço de redefinir seu interesse nacional conforme a necessidade de um dado momento.

Apesar dessa evolução da disciplina de Relações Internacionais, em que os temas de high politics e low politics passam a se confundir, observa-se a permanência do tradicionalismo das análises de política externa no Brasil, que ainda se voltam para as questões entre Estados, e ora analisam as relações bilaterais do Brasil, ora recortam a política externa segundo áreas temáticas em que os Estados são os atores predominantes (MILANEZ, 2013, p. 25).

Entretanto, as migrações internacionais se tornam um tema a cada dia mais relevante e que impõe desafios formidáveis aos formuladores e executores de política externa. O movimento de cidadãos entre as fronteiras dos Estados nacionais é tema estratégico e que envolve uma ampla diversidade de disciplinas (sociologia, antropologia, demografia, ciência política), e sua abordagem da perspectiva das Relações Internacionais se torna, portanto, indispensável para a compreensão de como o Estado brasileiro se posiciona quanto a esse assunto.

Eis o contexto em que se insere este trabalho, desenvolvido na linha de pesquisa "Política Internacional e Comparada" do Mestrado em Relações Internacionais do Instituto de Relações Internacionais da Universidade de Brasília. Trata-se de estudo exploratório que tem por objetivo mapear possíveis interações entre a política externa brasileira e a política migratória entre os anos de 1995 e 2010.

A migração internacional apresenta aspectos positivos e negativos para os migrantes, para os países de origem e para os países receptores. Martine (2005, p. 12) sugere uma relação não exaustiva acerca das vantagens da migração para os migrantes e seus lugares de origem, entre as quais aponta: i) as remessas financeiras, que promovem o dinamismo econômico e permitem uma mobilidade social que, de outra forma, seria difícil de alcançar; ii) o acesso, pelo migrante, a ideias, habilidades e valores que ajudam a apressar a modernização do país de origem; iii) o alívio de tensões sociais em países de economias estagnadas e com grande população jovem; iv) em certas condições, a emancipação da mulher; v) ao realizarem atividades que os nativos não querem fazer, e por salários baixos, os migrantes contribuem para a melhoria da qualidade de vida e redução de seu custo nos lugares de destino; vi) ao preencher lacunas demográficas e laborais, a migração promove a revitalização de sociedades envelhecidas; vii) os países de destino recebem, gratuitamente, uma grande quantidade 
de recursos humanos qualificados cujos custos foram internalizados por outros Estados; viii) os migrantes ajudam a reduzir a inflação e aumentar a produtividade, pois respondem melhor às mudanças no mercado de trabalho e reduzem sua rigidez; e ix) a migração expande a base de consumidores e de contribuintes. O autor enumera, ainda, algumas desvantagens geradas pelas migrações, tais como: i) a seletividade da migração e a "fuga de cérebros", isto é, a perda das pessoas mais criativas, trabalhadoras, empreendedoras e ambiciosas, o que pode levar a déficits de recursos humanos qualificados nos países de origem; ii) perseguição e maus-tratos aos migrantes em virtude de atitudes xenófobas e discriminação racial e social; iii) dificuldades de comunicação e adaptação, estresse psicológico, perda de identidade e do referencial afetivo; iv) o risco envolvido na migração, especialmente para mulheres e crianças; v) países receptores são palco de conflitos e tensões sociais que surgem das diferenças étnicas, linguísticas e religiosas; vi) risco de erosão da cultura nacional; vii) peso fiscal, pois, pelo menos no início, os imigrantes pressionam os serviços sociais, educacionais e de saúde; viii) maiores riscos para a segurança nacional em virtude do terrorismo; e ix) competição por empregos e redução dos salários dos locais, provocando reações de sindicatos ou grupos de pressão contrários à inserção dos migrantes no mercado de trabalho.

Em 2006, o Secretário-Geral das Nações Unidas publicou o relatório "Migração Internacional e Desenvolvimento", no qual afirma que a migração internacional beneficia as condições econômicas das áreas de origem e destino, com base em complementaridades existentes entre elas. Naquele ano foi realizado o primeiro Diálogo de Alto Nível sobre Migração Internacional e Desenvolvimento, a primeira reunião de alto nível da Assembleia-Geral que tratou exclusivamente dedicada ao tema. Desde então, as migrações têm sido objeto de frequentes debates na AGNU. Em outubro de 2013, a reunião do Diálogo de Alto-Nível adotou declaração final reconhecendo que a migração internacional "is a crosscutting phenomenon that should be addressed in a coherent, comprehensive and balanced manner, integrating development with due regard for social, economic and environmental dimensions and respecting human rights" e, ainda, "the important contribution made by migrants and migration to development in countries of origin, transit and destination, as well as the complex interrelationship between migration and development" (ONU, 2013a, p.1).

De acordo com estatísticas do Departamento de Assuntos Sociais e Econômicos das Nações Unidas, em 2013, o número de migrantes internacionais totalizou 232 
milhões, sendo que, em 1990, esse quantitativo era de 154 milhões e, em 2000, de 175 milhões. Entre 1990 e 2000, o estoque de migrantes internacionais aumentou a uma taxa de $1,2 \%$ ao ano. De 2000 a 2010, a taxa de crescimento acelerou, atingindo 2,3\% ao ano. Desde então, esse aumento reduziu-se para 1,6\% ao ano no período de 2010 a 2013 (ONU, 2013b). Desse modo, é possível prever um aumento das migrações internacionais nos anos vindouros, uma vez que, mesmo a uma taxa conservadora de $1 \%$ ao ano, o número de migrantes poderá chegar a cerca de 250 milhões até 2020.

Considerando o acima exposto, o argumento central desta dissertação parte da premissa de que é preciso entender a dinâmica eventualmente existente entre a política externa e a política migratória no Brasil, a fim de potencializar as vantagens e minimizar as desvantagens das migrações para a inserção internacional do País e para a gestão do fenômeno migratório em nível doméstico.

Ainda que seu foco seja a política externa brasileira, considera-se essencial destacar as contribuições das teorias de migrações para contextualizar as migrações internacionais na esfera da globalização. Os deslocamentos populacionais contemporâneos obedecem a dinâmicas próprias, cujo entendimento se faz necessário, primeiramente, para observar as causas da migração, identificar origens e destinos e vislumbrar possíveis tendências. A partir desses elementos, pode-se observar o comportamento dos Estados e avaliar em que medida as políticas migratórias por eles adotadas revelam-se adequadas ou não para o equacionamento das questões relacionadas às migrações.

Este trabalho tem por recorte temporal os governos de Fernando Henrique Cardoso e Luiz Inácio Lula da Silva. O recorte temporal se justifica por ser possível observar, nesse período, a evolução de uma nova política em relação aos brasileiros que vivem no exterior, com alterações importantes na sua estrutura de execução, bem como a adesão do Brasil a instrumentos de defesa dos direitos humanos de migrantes.

A pesquisa tem por objetivo explorar possíveis inflexões da política migratória brasileira em relação às ações da política externa no período, a partir da descrição dos processos de construção da estratégia de inserção internacional do Brasil, enfocando convergências e afastamentos que permitam identificar uma possível influência da política externa na política migratória.

A hipótese testada nesta dissertação é de que a política externa e a política migratória, no período de 1995 a 2010, evoluíram de forma concertada, tendo a política externa do Brasil exercido influência sobre a política migratória. 
O exame dessas políticas se fará, empiricamente, com base na leitura de discursos e pronunciamentos oficiais, leis, decretos, resoluções e na compilação de dados estatísticos. A unidade de análise é o Estado. Não se pretende abordar como a sociedade vê a atuação do Estado frente ao tema, embora menções a esse processo apareçam ao longo do texto.

Foram utilizadas fontes primárias (leis, decretos, tratados, discursos) e secundárias (artigos científicos, livros, teses e dissertações). Foram tratadas também como fontes primárias as entrevistas com representantes do Governo Federal. As estatísticas sobre a migração foram coletadas em estudos realizados por agências especializadas e instituições oficiais.

As entrevistas com representantes do Governo Federal foram realizadas em seus próprios gabinetes. Dessa forma, entende-se que o espaço de fala possa ser diretamente associado à posição institucional do órgão, uma vez que o entrevistado se apresenta na qualidade de representante. Utilizou-se um questionário semiestruturado, que consta de apêndice ao final do trabalho (Apêndice B), e facultou-se a todos os entrevistados não responderem a qualquer questão. Não houve negativa em responder às perguntas feitas e todas as entrevistas transcorreram normalmente. Foram usadas como método de registro anotações e gravação de áudio, com o consentimento prévio dos entrevistados.

As entrevistas realizadas indicam que há controvérsias sobre o assunto, de modo que haverá espaço, mais adiante, para aprofundar a análise do tema. Levando-se em conta que o método de análise é qualitativo e não quantitativo, considera-se que a limitação do número de entrevistas é menos impactante para a consecução da pesquisa. Ainda assim, elas foram muito importantes para qualificar informações específicas e para indicar aspectos do problema difíceis de serem percebidos apenas com base na literatura disponível.

Para alcançar seu objetivo, este trabalho está dividido em uma introdução, três capítulos e uma conclusão. A introdução apresenta o trabalho, seu objetivo, sua metodologia e sua organização.

O capítulo 1 apresenta a evolução da atuação internacional do Brasil e as principais tradições da política externa, tais como, a opção pelo multilateralismo, o respeito ao direito internacional e aos direitos humanos. Observam-se aspectos das políticas externa de FHC e de Lula sobre possíveis pontos de ruptura e traços de continuidade quanto ao discurso de solidariedade e de não indiferença, enfocando a cooperação sul-sul e seu papel na estratégia de inserção internacional do Brasil. 
No capítulo 2, discutem-se as teorias contemporâneas sobre o fenômeno migratório. Apresenta-se um histórico das migrações de e para o Brasil com base no contexto sócio-político-econômico brasileiro e mundial, as mudanças de perfil imigratório, a legislação desde os anos 1980 e as estatísticas de fluxos durante o período estudado. Descrevem-se as situações de aplicação tempestiva de medidas excepcionais em relação às linhas-mestras da política imigratória, analisando a atuação das entidades estatais em relação às políticas públicas para as migrações. O capítulo tem por objetivo subsidiar a análise do fenômeno migratório contemporâneo e apontar possíveis causas para sua intensificação. Além disso, trabalha a problemática da legislação anacrônica herdada do Regime Militar e a necessidade de sua revisão para uma migração mais favorável aos direitos humanos dos migrantes.

Por fim, no capítulo 3, busca-se observar as convergências e os distanciamentos entre as políticas externa e migratória que podem indicar ou não sua concertação e, sobretudo, identificar situações em que o discurso conflita com a prática. Por meio do mapeamento dos compromissos internacionais assumidos pelo Brasil, será possível observar o comportamento do Estado brasileiro em relação ao tema das migrações internacionais nesse particular. A esse mapeamento serão contrapostos os dados demográficos e informações estatísticas de órgãos oficiais, bem como as alterações na legislação migratória, a fim de determinar possíveis nexos de causalidade.

Além dos dados empíricos obtidos em fontes oficiais, busca-se complementar a análise com a percepção dos formuladores/executores da política migratória acerca dos movimentos da política externa e vice-versa, com o objetivo de extrair uma avaliação mais aprofundada sobre o comportamento dessas políticas e suas inter-relações. Por meio dessa metodologia, espera-se identificar pontos de convergência e analisar suas consequências para a formulação e execução das políticas externa e migratória, bem como seus impactos para a imagem do Brasil e o fortalecimento do soft power ${ }^{4}$ brasileiro.

$\mathrm{Na}$ conclusão, discutem-se os resultados em relação à hipótese inicial e apresentam-se algumas considerações sobre a possível evolução da política externa visà-vis a política migratória.

\footnotetext{
${ }^{4}$ Segundo a definição de Nye (2005), "a country's ability to influence events through persuasion and attraction, rather than military or financial coercion".
} 


\section{Capítulo 1: A Política Externa dos Governos de Fernando Henrique Cardoso e Luiz Inácio Lula da Silva}

\subsection{Antecedentes}

A partir do início dos anos 90, com o estabelecimento de uma nova ordem internacional, conformada pelo final da Guerra Fria e pela ideia da possibilidade de fortalecimento da cooperação internacional, o Brasil reformula parcialmente sua política externa. Em um contexto internacional não mais pautado pela bipolaridade do conflito Leste x Oeste, os chamados "novos temas", tais como, meio ambiente, direitos humanos, segurança, não-proliferação, interdependência econômica e migrações passam a integrar a agenda da política externa brasileira.

Primeiro presidente eleito democraticamente depois do fim do Regime Militar, Fernando Collor de Mello (1990-1992) construiu a campanha em tons populistas, propagando a imagem da mudança e modernidade que levariam o Brasil ao Primeiro Mundo (PECEQUILO, 2012, p. 215). A percepção da unipolaridade no sistema internacional levou o governo a priorizar a implementação parcial do Consenso de Washington. No âmbito multilateral, isso implicou o abandono das políticas de reivindicação e demandas do então chamado Terceiro Mundo, que somente seriam retomadas após o impeachment, no governo de Itamar Franco. Nesse período, os Ministros de Relações Exteriores foram Fernando Henrique Cardoso (1992-1993) e Celso Amorim (1993-1994). Coube a eles retomar a tradição global multilateral e investir na cooperação sul-sul com outras potências em desenvolvimento. (PECEQUILO, 2012, p. 217).

No espaço regional, o Brasil deu continuidade ao projeto do Mercosul, com a assinatura do Protocolo de Ouro Preto em 1994. O objetivo de alcançar reconhecimento político teve o foco deslocado da aquiescência para um incremento de participação, em particular na ONU, tendo como base a defesa da reforma do Conselho de Segurança e a candidatura brasileira a um assento permanente (PECEQUILO, 2012, p. 217). A mesma postura de reivindicação estende-se a outros organismos multilaterais com o país retomando sua identidade como país de Terceiro Mundo. A administração recuperou ações para a África que, em 1996, no governo FHC, robusteceram a Comunidade dos 
Países de Língua Portuguesa $\left(\right.$ CPLP) ${ }^{5}$, resultando em um estímulo nas relações comerciais com os países que a integram. Quanto aos Estados Unidos, apesar de algumas críticas norte-americanas ao governo, não houve conflitos sérios. Embora o país não fosse considerado um "modelo" pelos EUA como o são Argentina e Chile nesse momento, não há uma baixa significativa na diplomacia como no final dos anos 1980. A grande conquista de Itamar Franco ocorreu na dimensão interna, com a implementação do Plano Real (1994) de estabilização da economia, a cargo do então Ministro da Fazenda Fernando Henrique Cardoso (FHC), eleito presidente nas eleições daquele ano.

\subsection{Os anos FHC (1995-2002)}

Ao longo dos oito anos de seu governo, FHC buscou substituir a agenda reativa da política externa brasileira, dominada pela lógica da "autonomia pela distância", que prevaleceu na maior parte dos anos em que durou a Guerra Fria, por uma nova agenda internacional proativa, denominada por Vigevani et al. (2003) de "autonomia pela integração". Diferente do perfil global-multilateral da política externa empreendido por Itamar Franco, FHC recuperou as premissas e lógica do início dos anos 1990, sustentada no bilateralismo (PECEQUILO, 2012).

Embora de uma forma mais equilibrada do que Collor e outros governos latinoamericanos, FHC investiu na tática da "integração" ao sistema via credibilidade e legitimação nacional por meio da adesão aos regimes internacionais e da retomada dos processos de abertura e privatização interrompidos por Itamar. A visão do Brasil como um país do Terceiro Mundo ou periférico foi trocada pelo ideário do (ainda assim denominado) Primeiro Mundo e de uma nova era da política mundial sustentada nas premissas do neoliberalismo e da governança mundial. Apesar de FHC sustentar seus alinhamentos de um ponto de vista pragmático, sem o automatismo de seu antecessor, o eixo vertical predominava sobre o horizontal, privilegiando a tradição bilateralhemisférica.

\footnotetext{
${ }^{5}$ As origens da CPLP remontam ao governo de José Sarney. Em 1989, foi realizado o Primeiro Encontro de Chefes de Estado das Comunidades de Língua Portuguesa, que contou com a presença de Angola, Brasil, Cabo Verde, Guiné-Bissau, Moçambique, Portugal e São Tomé e Príncipe (PECEQUILO, 2012). Atualmente, além dos citados, fazem parte da CPLP o Timor-Leste e a Guiné Equatorial, cuja adesão ocorreu em 2014, totalizando 9 países.
} 
Na visão de Vigevani et al. (2003), as diretrizes da política externa brasileira na Era FHC respeitaram parâmetros tradicionais: pacifismo, respeito ao direito internacional, defesa dos princípios de auto-determinação e não-intervenção, pragmatismo como instrumento necessário e eficaz à defesa dos interesses do País.

Nas relações internacionais, em 1995, o Brasil participou da criação da OMC, no encerramento da Rodada Uruguai do GATT (Ata de Marrakesh) e aderiu ao MTCR (Regime de Controle de Tecnologias de Mísseis). O Congresso Nacional aprovou a Lei das Patentes (1996) e a Cultivares (1997), importantes instrumentos de proteção à propriedade intelectual. No campo da não proliferação nuclear, o Brasil já ratificara o Tratado de Tlatelolco e seus compromissos com o CTBT, deixando clara sua opção pela paz e por uma América Latina e um sistema internacional livre de armas nucleares. O movimento mais simbólico desse processo de adesão aos regimes foi a ratificação do Tratado de Não Proliferação (TNP), em 1998, um marco na agenda de reinserção internacional do Brasil como um país confiável e legítimo, apesar de ter recebido e ainda receber muitas críticas no nível doméstico. Ao aderir aos regimes de não proliferação, cumpriu-se o objetivo de resgatar as "hipotecas" que ainda pesavam sobre a credibilidade externa do País (LAMPREIA, 1998, p. 13).

Essas iniciativas refletem os novos posicionamentos do Brasil, que vinham sendo construídos desde a redemocratização. A adesão do Brasil ao TNP constituiu o exemplo mais emblemático de revisão de posições anteriores em arranjos já em vigor (MELLO, 2012). Para o Brasil, no mundo pós-Guerra Fria, a autonomia da política externa não poderia mais ser promovida por meio do distanciamento com relação aos arranjos internacionais. Pelo contrário, a estratégia para incidir sobre os efeitos da assimetria internacional consistiu em reforçar a necessidade da presença e da participação nesses foros, com vistas a exercer influência internamente sobre as novas dinâmicas do multilateralismo no contexto da globalização. Assim, foram também revistas posições até então defensivas do Brasil em relação aos temas do meio ambiente e dos direitos humanos.

No que se refere aos temas de meio ambiente, a candidatura da cidade do Rio de Janeiro para sediar a cúpula das Nações Unidas sobre meio ambiente havia sido formalizada já no final da década de $1980^{6}$, demonstrando que o País passaria a aceitar a legitimidade de um marco normativo multilateral para a regulação das políticas

\footnotetext{
6 "Pela Resolução 44/228, aprovada pela Assembleia Geral das Nações Unidas, em 22 de dezembro de 1989, foi aceito o oferecimento do Governo brasileiro para sediar a Conferência”" (LAGO, 2006, p. 66).
} 
ambientais, em contraste com as resistências anteriormente vigentes. A atuação da diplomacia brasileira orientou-se no sentido de influir na conformação dos arranjos multilaterais que decorreriam da Conferência, para impedir que refletissem exclusivamente os interesses dos países desenvolvidos e projetar um novo papel internacional do Brasil (MELLO, 2012).

Quanto aos direitos humanos, o Brasil passou a ser signatário dos mais importantes tratados internacionais de Direitos Humanos, tanto no âmbito das Nações Unidas (ONU), como no da Organização dos Estados Americanos (OEA), destacandose: a Convenção para a Prevenção e a Repressão do Crime de Genocídio (1948); a Convenção Relativa ao Estatuto dos Refugiados (1951) e seu Protocolo (1967); o Pacto Internacional sobre Direitos Civis e Políticos e seu Protocolo Facultativo (1966); o Pacto Internacional dos Direitos Econômicos, Sociais e Culturais (1966); a Convenção Contra a Tortura e Outros Tratamentos ou Penas Cruéis, Desumanos ou Degradantes (1984); e a Convenção Americana sobre Direitos Humanos (1969). ${ }^{7}$ Nesse sentido, cabe ressaltar a decisão, em 1998, de aceitar a competência jurisdicional obrigatória da Corte Interamericana de Direitos Humanos. ${ }^{8}$

A reinserção do Brasil no sistema internacional fazia parte do programa de governo de FHC, que previa a necessidade de fortalecimento do sistema internacional para que este, mais seguro, justo e democrático, fosse instrumento de uma política externa que visava à realização de objetivos políticos e econômicos. A tônica do primeiro governo de Fernando Henrique Cardoso esteve muito voltada ao sistema internacional, à inserção do Brasil neste e na maneira como o Brasil poderia atuar na construção de uma nova ordem mundial que seria a base da retomada do desenvolvimento econômico.

A cooperação internacional passou a funcionar como um eixo de preocupação do governo FHC. Para o presidente, a "globalização" produziu uma nova comunidade de interesses entre Norte e Sul. Os países deveriam aceitar certos condicionantes da ordem

\footnotetext{
${ }^{7}$ Atualmente, no Brasil, já se encontram ratificados e em pleno vigor praticamente todos os tratados internacionais significativos sobre Direitos Humanos pertencentes ao sistema global, de que são exemplos, a Convenção Internacional sobre a Eliminação de Todas as Formas de Discriminação Racial (1965), a Convenção sobre a Eliminação de Todas as Formas de Discriminação Contra a Mulher (1979) e seu Protocolo Facultativo (1999), a Convenção sobre os Direitos da Criança (1989) e, ainda, o Estatuto de Roma do Tribunal Penal Internacional (1998) (GOMES e MAZZUOLI, 2005).

${ }^{8}$ Pelo art. 1ㅇ do Decreto no 4.463 , de 8 de novembro de 2002, o Brasil reconhece "como obrigatória, de pleno direito e por prazo indeterminado, a competência da Corte Interamericana de Direitos Humanos em todos os casos relativos à interpretação ou aplicação da Convenção Americana de Direitos Humanos (Pacto de São José), de 22 de novembro de 1969, de acordo com art. 62 da citada Convenção, sob reserva de reciprocidade e para fatos posteriores a 10 de dezembro de 1998".
} 
econômica mundial como o realismo e o pragmatismo para que pudessem contrapor-se aos efeitos negativos da "globalização", que foi rotulada de "assimétrica" (VIZENTINI, 2005, p. 385). Desta maneira, a cooperação regional e inter-regional seriam as prioridades da política externa brasileira no período.

O Brasil tinha por objetivo marcar presença no cenário internacional, com aspirações de desempenhar um papel de relevo e a pretensão de reivindicar uma vaga como membro permanente no Conselho de Segurança da Organização das Nações Unidas. Assim, é possível perceber que, se durante os governos Fernando Collor e Itamar Franco a intenção de assumir papel de maior relevo na cena internacional já se manifestara, com FHC essa ambição se tornou ainda mais acentuada (CARDOSO, 1994).

FHC exerceu a Diplomacia Presidencial durante seus dois mandatos, apresentando-se como porta-voz e face do Brasil no sistema internacional. A intensificação das viagens ao exterior, a participação em reuniões e cúpulas bilaterais e multilaterais, a visibilidade em organizações internacionais teve espaço importante. FHC imprimia à imagem brasileira um alto perfil, condizente com a agenda que defendia nas relações internacionais de eixo vertical, tornando-se líder de uma nova geração de líderes latino-americanos comprometidos com a inserção moderna de suas sociedades. A percepção de Fernando Henrique sobre as mudanças no sistema internacional também é evidenciada de forma muito clara no programa de governo do então candidato à Presidência.

\begin{abstract}
Ao processo de globalização aliou-se a tendência para a formação de diferentes modalidades de regionalização econômica. Esses dois movimentos, que não são contraditórios, tendem a alterar as formas de inserção internacional dos países. A interdependência agora criada em escala planetária, ainda que assimétrica, aponta para a inviabilidade dos projetos nacionais de natureza autárquica. Ao mesmo tempo, ampliou-se de forma significativa a agenda diplomática. Muitos temas, tais como meio ambiente, direitos humanos, propriedade intelectual, explosão demográfica, as grandes fomes e migrações, o combate ao terrorismo e ao narcotráfico, exigem hoje soluções globais. (...) É nesse sentido que se diluem cada vez mais as fronteiras, não apenas entre mercados, mas também entre a política externa e a política interna das nações. Isto não implica a abolição de tensões e de conflitos de interesses entre as partes interdependentes. Por isso, o reconhecimento desse novo estado de coisas não pode implicar renúncia à defesa de interesses nacionais ou a princípios consagrados do direito internacional (CARDOSO, 1994).
\end{abstract}

Para FHC, deveria haver convergência entre $\mathrm{o}$ arcabouço institucional internacional e o quadro regulatório interno dos países, ou seja, variáveis externas 
passariam a ter maior influência nas decisões internas. A integração à economia mundial passaria necessariamente pela articulação de uma prática diplomática adequada, pela construção de parcerias comerciais vantajosas e por reformas internas.

Essa dinâmica vertical, mas de responsabilidade e legitimidade, levaria ao reconhecimento do país como pilar da nova ordem a partir da solidez de seu status como potência e de seus compromissos. Em termos concretos, as ações brasileiras, somadas à Diplomacia Presidencial, consistiram na retomada da implementação, embora incompleta, do Consenso de Washington e do projeto de privatizações, introduzindo as reformas da segunda geração no campo social.

O próprio Fernando Henrique Cardoso, em artigo publicado em 2001 pela Revista Brasileira de Política Internacional, descreve que, desde meados dos anos 80, o Brasil passou por três transformações essenciais que influenciam a política externa: a redemocratização, a abertura de mercados e a estabilização da moeda. Para o expresidente, essas mudanças foram fundamentais na construção de um novo Estado, e as privatizações fizeram parte deste processo. É certo que todas essas mudanças fizeram com que a posição do Brasil no cenário internacional se modificasse, tanto em termos de sua atuação quanto na avaliação que as outras nações faziam do Brasil. Para Cardoso (2001), a partir de meados dos anos 80, mas principalmente nos anos 90, o Brasil passa a ter melhor relacionamento com a comunidade internacional, principalmente em temas como estabilidade monetária, direitos humanos, meio ambiente e não proliferação nuclear (CARDOSO, 2001, p. 5 e ss.), para o que foi essencial a primeira das três transformações apontadas, ou seja, a redemocratização.

Para Fernando Henrique Cardoso, os novos temas representavam elemento bastante importante da política externa. Assim, nas palavras do então presidente,

\footnotetext{
abrimos caminho para um melhor relacionamento com a comunidade internacional em todos os temas que, no passado, haviam sido sensíveis, como os direitos humanos, o desenvolvimento social, o meio ambiente ou a não-proliferação nuclear (CARDOSO, 2001, p. 6).
}

O Brasil se adaptou ao corolário neoliberal então em voga no sistema internacional e, estando mais integrado aos fluxos financeiros internacionais, passou a sofrer por ocasião das instabilidades externas típicas do sistema capitalista, as quais tiveram impactos significativos na economia nacional. O Brasil sentiu as consequências das crises financeiras, como as do México (1995), dos tigres asiáticos (1997), da Rússia 
(1998) e da Argentina (2001), com fortes impactos sobre o nível de reservas internacionais.

Gráfico 1. Reservas Internacionais (1995-2002) - em US\$ bilhões

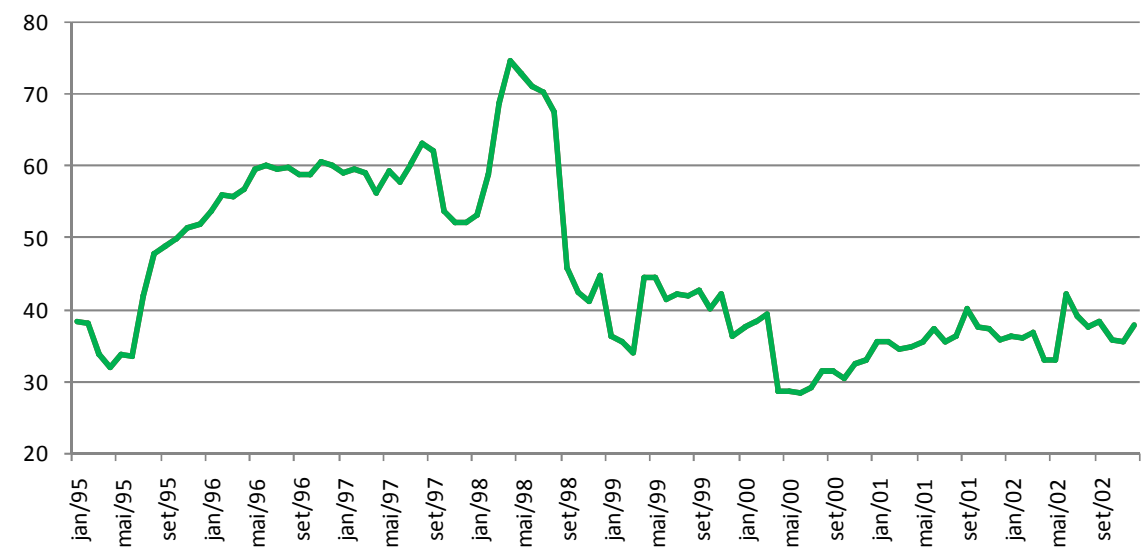

Fonte: Banco Central do Brasil.

A fim de conter ataques especulativos contra o Real, o governo brasileiro elevou fortemente a taxa básica de juros da economia, conforme apresentado no gráfico 2.

Gráfico 2. Variações da Taxa Básica de Juros - SELIC (1996-2002)

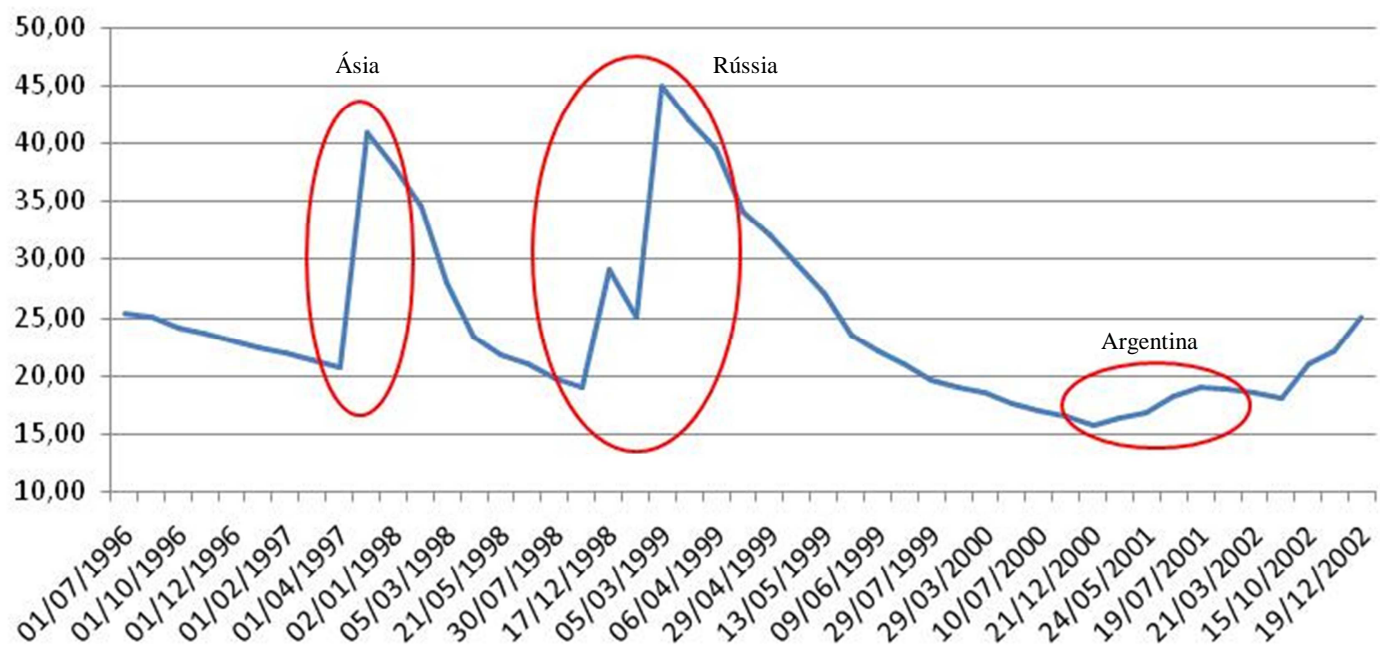

Fonte: Banco Central do Brasil.

Obs.: A série histórica do Banco Central sobre a taxa de juros SELIC tem início em 1996, com a criação do Comitê de Política Monetária (COPOM).

As crises financeiras tiveram como consequência uma oscilação sensível nos níveis de ingressos de investimento estrangeiro direto no Brasil no período. 


\section{Gráfico 3. Ingressos de Investimento Estrangeiro Direto (1995-2002) - em US\$ bilhões}

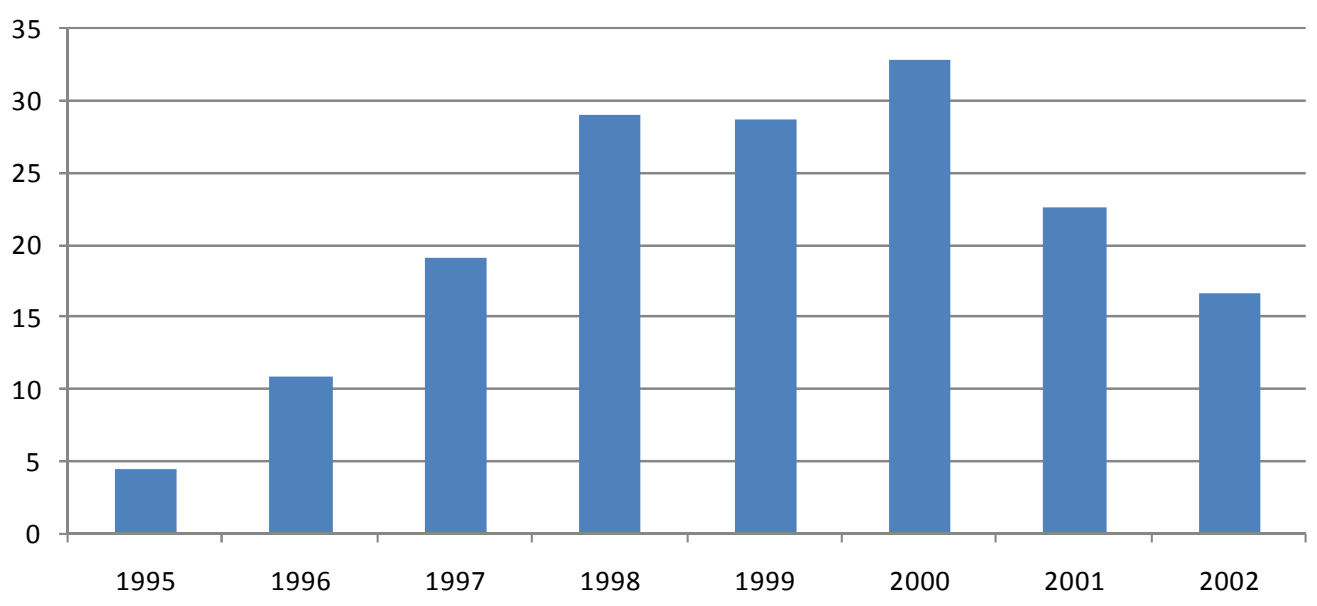

Fonte: UNCTAD.

No enfretamento de crises sistêmicas, a cooperação e a coordenação internacionais eram para o governo Fernando Henrique Cardoso algumas de suas principais preocupações. Para o presidente, a pergunta que se deveria fazer era: "até onde poderemos ir na direção de crescentes fluxos transnacionais e de uma interdependência internacional cada vez maior sem o desenvolvimento proporcional de estruturas de governança?" (CARDOSO 2001, p. 8). Uma arquitetura financeira internacional mais estável e previsível teve no G-209 um importante passo.

Se a crescente globalização não for acompanhada pela necessária cooperação e coordenação de políticas, não será surpresa se ela terminar sendo percebida como o império das empresas ou que ela suscite protestos veementes (CARDOSO, 2001, p. 10, grifos originais).

Segundo Cervo (2002), a ideia de mudança advogada por Fernando Henrique Cardoso, fez com que se estabelecesse de forma predominante na política exterior do Brasil o que denomina de paradigma do "Estado normal". Para esse autor, a via escolhida por FHC implicava aceitação e aplicação de reformas exigidas pelo Consenso de Washington. Desta maneira, as duas outras transformações, a abertura econômica e a estabilização da moeda, estariam mais relacionadas com a necessidade de estabilidade interna para a obtenção de recursos importantes para a retomada do crescimento.

\footnotetext{
${ }^{9}$ O G-20 é um grupo de consultas informais entre Ministros de Finanças e presidentes de Bancos Centrais no âmbito das instituições de Bretton Woods para discussão de questões econômicas e financeiras globais. A primeira reunião ocorreu em Berlim em 1999 e contou com a participação de representantes das economias consideradas mais significativas em nível mundial naquele momento: África do Sul, Alemanha, Arábia Saudita, Argentina, Austrália, Brasil, Canadá, China, Coreia do Sul, Estados Unidos, França, Índia, Indonésia, Itália, Japão, México, Reino Unido, Rússia e Turquia, além da União Europeia.
} 
De fato, as privatizações talvez sejam os exemplos mais claros de como o Brasil se adaptou ao Consenso de Washington como estratégia de inserção internacional e de como a ordem internacional vigente incidiu na política interna. Convém lembrar, porém, que o movimento de desestatização ganhou forte impulso no governo Collor, tendo prosseguido no governo Itamar Franco e sido executado com novo ímpeto nos dois mandatos de Fernando Henrique Cardoso. Grande parte dos investimentos externos diretos no Brasil durante os governos FHC teve origem nas privatizações, que contribuíram para modernizar a infraestrutura e aliviar a dívida pública (FOLHA, 1997).

Houve forte articulação entre política externa e política econômica. As privatizações como fonte de atração de investimentos externos diretos são exemplos de como a ordem internacional incide na política interna e como atos internos enquadramse na estratégia de inserção internacional. A política externa de FHC é marcada pela adoção do modelo neoliberal e da globalização econômica (CERVO, 2002).

Se considerarmos que a "era FHC" na política externa começa em 1992 quando este assume o posto de chanceler, temos que é no início desta que o conceito do universalismo ressurge na política externa brasileira. Este conceito é empregado no sentido de que o Brasil deve manter suas opções internacionais abertas mesmo que o sistema internacional de poder aponte uma nação como hegemônica. Da mesma forma, é no primeiro governo de Fernando Henrique Cardoso que o conceito de autonomia é redefinido e reincorporado na atuação internacional do Brasil.

Para Flavia de Campos Mello (2012), o paradigma universalista foi o que predominou nos anos anteriores ao governo FHC. Para a autora, faziam parte deste paradigma quatro conceitos fundamentais: diversificação, universalismo, autonomia e interdependência. É interessante notar que, segundo Mello, o universalismo é expresso neste período principalmente através do regionalismo. A valorização do espaço regional propicia a reafirmação da autonomia, ou seja, é integrando-se regionalmente que o Brasil pode atuar com mais autonomia nos foros internacionais. A integração regional traz consigo uma maior liberdade de atuação em esferas supranacionais em que, geralmente, um país como o Brasil não tem força isoladamente.

Mello (2012) acredita que "autonomia" é um conceito-chave para entendermos a ação externa do Brasil no período em que Fernando Henrique Cardoso ocupou a Presidência da República. A atuação internacional passa a ter dois novos eixos: a autonomia em relação aos Estados Unidos, o que de maneira nenhuma podia excluir-nos de manter relações bilaterais com este país, e a centralidade que a integração sub- 
regional e sul-americana passa a ter na possibilidade de inserção autônoma do Brasil no sistema internacional. O chanceler Lampreia (2010, p. 229 e ss.) denominou este tipo de estratégia de "autonomia pela integração", ao que Gelson Fonseca apresenta como "autonomia pela participação", em contraste com a "autônoma pela distância" promovida pela Política Externa Independente e pelo Pragmatismo Responsável.

A ideia do desenvolvimento independente não tem mais ressonância, ou seja, a autonomia pela distância não representa mais uma opção conveniente aos formuladores da política exterior do Brasil. No entanto, não se pode dizer que durante o governo Cardoso a política externa não continue voltada para a realização de objetivos vinculados ao desenvolvimento, mesmo que este venha através da adequação da agenda aos valores hegemônicos universalmente aceitos. O Brasil optou, neste momento, por avançar na integração hemisférica a partir da consolidação do Mercosul, não enfrentando diretamente os Estado Unidos. Apesar da aproximação com a maior potência do globo, o Brasil busca também diversificar suas parcerias nas relações internacionais, fortalecendo a posição multilateralista e sua presença na Organização Mundial do Comércio (OMC). Deste processo, também faz parte uma maior e mais enfática aproximação com a União Europeia.

O Brasil almeja uma posição de maior destaque na arena internacional, em linha com a percepção de que o tamanho de sua população, suas dimensões continentais e seus recursos naturais abundantes contribuiriam para lhe conferir peso correspondente, ampliando sua influência no processo decisório internacional.

Um dos traços predominantes do governo de Fernando Henrique Cardoso, apontado pela maioria dos autores, foi a utilização em larga escala da diplomacia presidencial, definida pelo Embaixador Sergio Danese, em sua obra já clássica sobre o tema, como "a condução pessoal de assuntos de política externa, fora da mera rotina ex officio, pelo presidente, ou, no caso de um regime parlamentarista, pelo Chefe de Estado e/ou pelo Chefe de Governo" (DANESE, 1999, p. 51).

Além de um fenômeno político, trata-se de instrumento de promoção dos interesses nacionais pela pessoa do presidente da República. A ação diplomática, de maneira geral, objetiva persuadir, pressionar e vincular os diversos atores internacionais aos interesses de um Estado. No governo Fernando Henrique, esses interesses foram perseguidos por meio de uma ação internacional baseada na atuação do Chefe do Poder Executivo como protagonista e centro das atenções da mídia brasileira e internacional. 
Nos governos que o antecederam, a ação internacional por meio da diplomacia presidencial não teve o alcance e a intensidade empregada por FHC.

\begin{abstract}
A própria mudança da importância relativa do país na região e no mundo, a alternância de regimes autoritários e democráticos, a experimentação constante de estruturas políticas e de políticas econômicas, o desinteresse relativo da opinião pública e das elites políticas pelos assuntos internacionais, diminuindo a prioridade da política externa na agenda interna, o isolamento e a xenofobia de parcelas das elites políticas, a ênfase no interno e no conjuntural, a ocorrência de crises políticas e choques econômicos, a ocorrência de momentos de retração internacional do país devido a crises como a da dívida e da hiperinflação, as dificuldades de acesso aos parceiros devido às percepções externas sobre o país e suas políticas, etc., também vão modulando a diplomacia presidencial brasileira (DANESE, 1999, pp. 473474).
\end{abstract}

O novo realce dado à diplomacia presidencial nesse período deve-se a dois fatores: a intensidade da agenda política externa do presidente e a própria figura de FHC, sociólogo de renome internacional. Além disso, sua experiência prévia como Chanceler no governo de Fernando Collor não deve ser desconsiderada como fator a ter influenciado sua postura como estadista.

Assim, as políticas interna e externa se conjugavam para dar segurança aos investidores internacionais com o objetivo de atrair capitais para o Brasil. Para Danese (1999), as modalidades de compromissos internacionais são quatro: encontros multilaterais internacionais, encontros regionais, posses presidenciais e visitas bilaterais. Foi acionada com bastante vigor, nos foros multilaterais, como na ONU (Organização das Nações Unidas), OMC (Organização Mundial do Comércio) e UNCTAD (Conferência das Nações Unidas sobre Comércio e Desenvolvimento) e nas relações bilaterais. A diplomacia presidencial de Fernando Henrique Cardoso tinha como um de seus principais objetivos a promoção internacional do Brasil do Real e das reformas.

Desta forma, a diplomacia de visitas promove e divulga o país no exterior com o objetivo de elevar o nível de participação do Brasil nos foros decisórios, explorar a estabilização econômica, mobilizar o governo, os meios políticos e empresariais e a sociedade civil, além de atualizar e aperfeiçoar as relações com parceiros-chave, promovendo novas parcerias. No governo FHC, as viagens internacionais

traduzem também uma estratégia deliberada de nos valermos dos instrumentos dos encontros de cúpula, com sua capacidade única de mobilizar os meios governamentais, a imprensa e a opinião pública, para promover uma atualização da presença brasileira no mundo (DANESE, 1999, p. 37). 
Os atentados terroristas de 11 de setembro de 2001 e as dificuldades colocadas a partir das negociações da Rodada de Doha acabaram influenciando os formuladores de políticas, somando-se a um quadro internacional em mutação, e conectando-se com as diferentes trajetórias políticas de FHC e de seu sucessor, Lula (VIGEVANI e CEPALUNI, 2007). No campo dos valores, conforme as diretrizes subjacentes à ideia da "autonomia pela participação", FHC defendeu princípios de direitos humanos e formas sustentáveis de desenvolvimento, procurou preservar a paz e a democracia, buscando objetivos "universalistas", como uma maior institucionalização, maior transparência nas decisões e uma crescente democratização das organizações e regimes internacionais (CARDOSO, 2006, p. 602).

O governo de FHC introduziu uma nova atitude nas estratégias da política externa do Brasil, preconizando uma intervenção mais ativa na política internacional, demonstrada através da vontade de influenciar o desenho da nova ordem e a necessidade de reformar o discurso e a ação no exterior. O governo FHC, ao consolidar e renovar o paradigma da política externa brasileira na segunda metade dos anos de 1990, conferiu um novo significado ao conceito de autonomia: o de "autonomia pela integração" (VIGEVANI et al., 2003, p. 37). Entre os resultados das mudanças favoráveis ao Brasil nos mandatos de FHC podem ser citados: a confiabilidade despertada pelo país no exterior, possibilitando a atração de investimentos externos diretos, significativamente importantes para o sucesso da estabilidade macroeconômica; o apoio de organismos multilaterais e de governos de países desenvolvidos em momentos de ameaça de crise financeira e econômica, como a crise cambial de 1999; aumento significativo da ênfase das relações exteriores na agenda interna, despertando maior atenção e interesse por parte da sociedade e dos meios de comunicação (VIGEVANI et al., 2003).

Os dois mandatos de FHC foram marcados, portanto, pela diplomacia presidencial, pela aposta na região sul-americana através da integração regional e na revalorização do Mercosul, pela adesão aos regimes internacionais, e, num segundo momento, pela intensificação do multilateralismo. A diplomacia presidencial valorizou a inserção internacional do país, mas não diminuiu a importância da afirmação regional do Brasil. FHC quis conciliar duas dimensões, sendo uma global e outra mais centrada na América do Sul, espelhada na postura de participação e de integração do Brasil, não apenas em termos regionais, mas também no que se refere às normas e aos regimes internacionais. Nesse sentido, foi possível registrar também uma coincidência entre a 
definição da identidade do Brasil e os valores universais, o que Luiz Felipe Lampreia denominou de "convergência crítica" (FONSECA, 2011).

Para Vigevani et al. (2003), a política externa brasileira durante o governo FHC contribuiu para posicionar o Brasil entre os países que aderem a valores considerados universais. Como resultado, melhorou o conceito internacional em relação ao Estado brasileiro, consolidando-se a conduta pacífica do país, respeitado por suas posições construtivas. Por outro lado, os autores destacam que o governo não foi capaz de promover o desenvolvimento em bases sustentáveis, tendo como efeito

\begin{abstract}
a continuação de uma tendência histórica de encolhimento do peso do Brasil na economia mundial, contribuiu para enfraquecer seu poder em negociações internacionais relevantes. A imagem negativa que a opinião pública dos países ricos tem dos países pobres, assim como os problemas internos que nos atingem especificamente, contribuíram para dificultar a maximização de vantagens. Na América Latina, a busca de protagonizar um papel mais relevante acabou enfraquecida pelos próprios constrangimentos internos (VIGEVANI et al., 2003, p. 58).
\end{abstract}

Compreender as posições da política externa brasileira durante os mandatos de Fernando Henrique é essencial para observar como o governo brasileiro tratou os temas migratórios no período. O capítulo 3 apresentará uma análise mais aprofundada a respeito das principais repercussões, na política migratória, das opções de política externa de FHC. Por ora, parece suficiente sugerir que a busca pela reinserção internacional do Brasil teve como consequências principais: i) a elevação do perfil internacional do país, em decorrência da exposição pessoal do presidente da República e das atuação da diplomacia em foros multilaterais. ii) a consciência da necessidade de traduzir compromissos assumidos pelo país no âmbito multilateral em políticas públicas em âmbito doméstico. No que se refere às migrações internacionais, isso terá sido feito na medida das capacidades do governo e das prioridades atribuídas ao tema pelos formuladores da política externa, conforme veremos adiante.

Passamos, a seguir, a apresentar um breve retrospecto da política externa no governo Lula, iniciado em 2003.

\title{
1.3. Os anos Lula (2003-2010)
}

Entre os anos de 2003 e 2010, a política externa brasileira "orientou-se pela concepção de que o Brasil deve assumir um papel crescente no cenário internacional, projetando uma imagem externa altiva e soberana" (BRASIL, 2010b). O Governo Lula 
reorientou a diplomacia para o estabelecimento de relações diplomáticas com todos os Estados do globo, por meio de novas representações diplomáticas. Entre os anos de 2003 e 2010, foram abertas 46 novas Embaixadas, sendo que 4 delas estavam desativadas e foram reabertas, e 22 novos Consulados-Gerais, Consulados ou ViceConsulados entraram em operação (Apêndice A).

Além disso, o governo buscou uma presença maior em fóruns internacionais, por meio de candidaturas em postos-chave em organizações intergovernamentais. Reorientou parcerias estratégicas com países do Sul, movimento que também teve reflexo nas ações de cooperação. Em suma, atuou de forma proativa com o objetivo de aumentar sua influência em temas da governança global, como política, economia e segurança internacional. Em linha com essa postura, observa-se o incentivo ao multilateralismo para a resolução de crises, refletido pelo aumento de participação brasileira na ONU e a reivindicação por reformas no Conselho de Segurança. O Brasil passa a participar com maior intensidade em operações de paz sob a égide das Nações Unidas. Em janeiro de 2003, o Brasil participava de duas missões de paz da ONU, com 79 homens. Em setembro de 2010, integrava nove missões de paz, com 2.258 contingentes, além de seis integrantes de dois escritórios de representação da ONU, totalizando 2.264 pessoas (BRASIL, 2010b).

No governo FHC, e no de Lula, em especial, a política externa é motivada pelo ideal de uma globalização mais democrática, que orienta para uma estratégia "logística" de inserção internacional do Brasil. Essa estratégia se processa mediante a ocorrência de dois fatores: i) alto grau de organização da sociedade, que facilita o trabalho de coordenação dos dirigentes; e ii) estabilidade política e econômica, que liga a lógica interna do governo à lógica de governança global. A partir da combinação desses fatores postos a serviço do desenvolvimento surge o Estado logístico, e sua conduta difere da conduta do Estado neoliberal principalmente na recuperação da autonomia política e no reforço da economia nacional (CERVO, 2010, p. 10).

Em paralelo, Lula procurou inserir temas sociais na agenda internacional, desde sua presença, em janeiro de 2003, na reunião do Fórum Econômico Mundial, em Davos (Suíça), defendendo o aumento da ajuda externa dos países ricos para o combate à fome, conseguindo o apoio dos presidentes Chirac (França) e Lagos (Chile) (VIGEVANI e CEPALUNI, 2007, p. 281). Em paralelo, durante esse período, a economia brasileira despontou como uma das mais pujantes do mundo em desenvolvimento. Resultados importantes foram alcançados com a valorização das commodities no mercado 
internacional, colocando o País como um dos destinos preferenciais de investimento externo direto (IED) (CEPAL, 2010), em razão da abundância de matéria-prima, mãode-obra mais barata e ambiente de oportunidades de negócio, ao lado de juros elevados. O gráfico 4 a seguir apresenta os valores de IED recebidos pelo Brasil no período em análise.

Gráfico 4. Ingressos de Investimento Estrangeiro Direto (2003-2010) - em US\$ bilhões

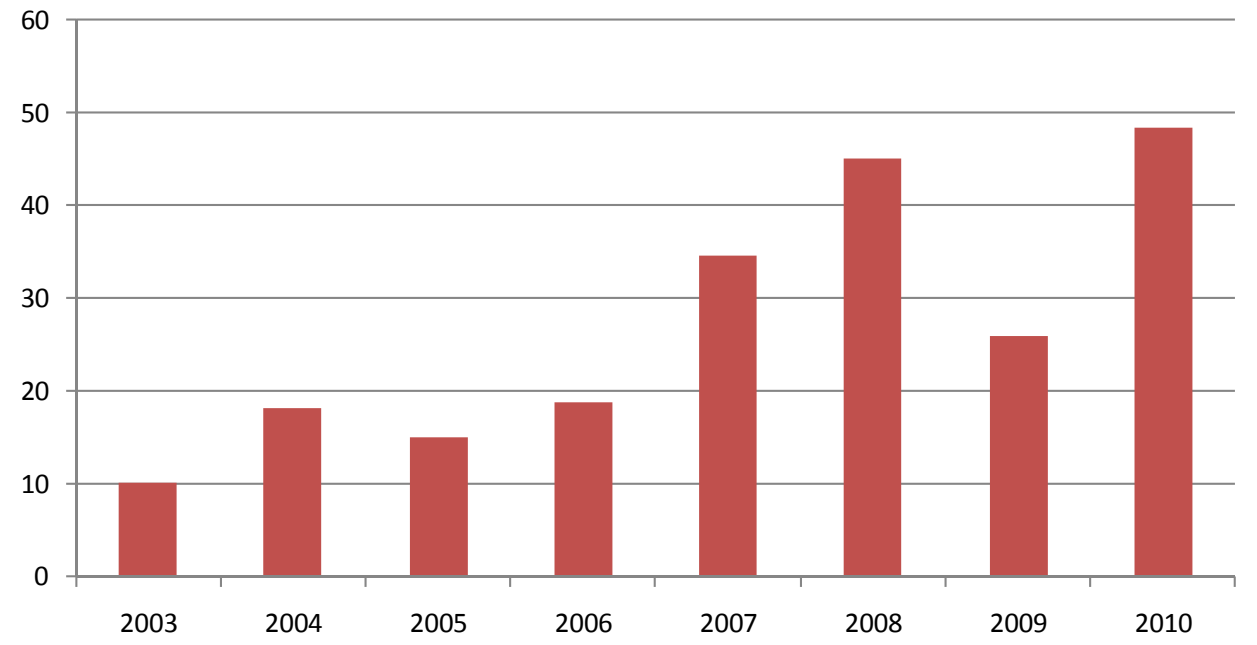

Fonte: UNCTAD.

Em 2002, as entradas de IED totalizaram US\$ 17 bilhões. Em 2003, tiveram redução, chegando a US\$ 10 bilhões, devido à incerteza dos investidores em relação ao novo governo. Após a queda de 2009 provocada pela crise financeira mundial, o ingresso de IED teve novo aumento, fechando o período em US\$ 48.5 bilhões. Com isso, as reservas internacionais do Brasil, que ao final do governo FHC chegavam a US\$ 37 bilhões, ao final do governo Lula atingiram a marca de US\$ 289 bilhões.

Gráfico 5. Reservas Internacionais (2003-2010) - em US\$ bilhões

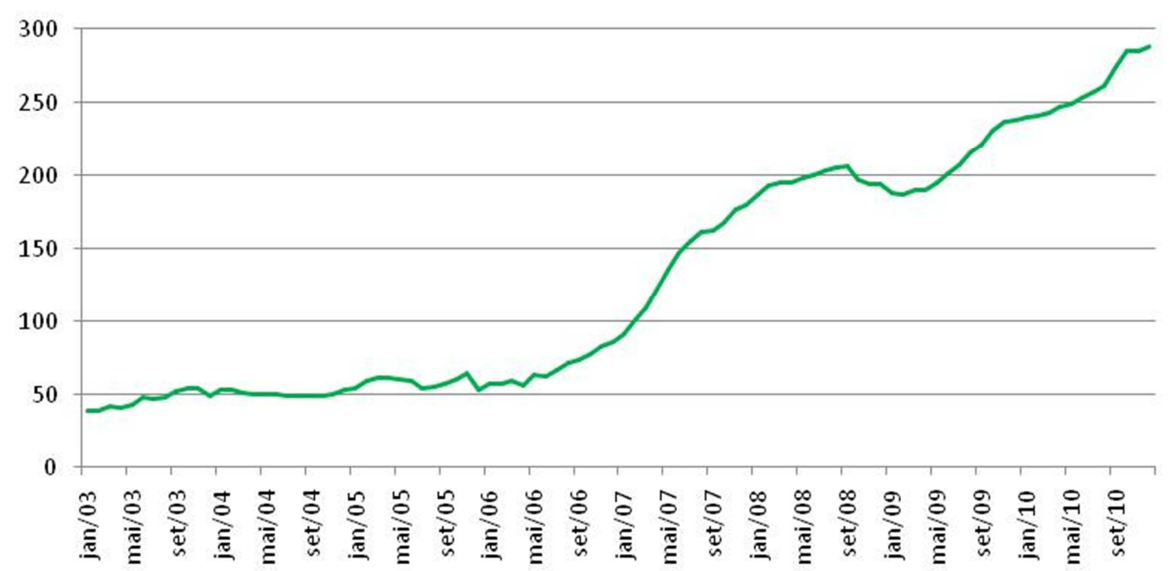

Fonte: Banco Central do Brasil. 
O bom momento econômico tornou possível a redução das taxas de juros da economia, com uma queda sensível em relação ao patamar do final do governo FHC ( $25 \%$ a.a.) para encerrar o ano de $2010 \mathrm{em} \mathrm{10,75 \%} \mathrm{a.a.}$

Gráfico 6. Variações da Taxa Básica de Juros - SELIC (2003-2010)

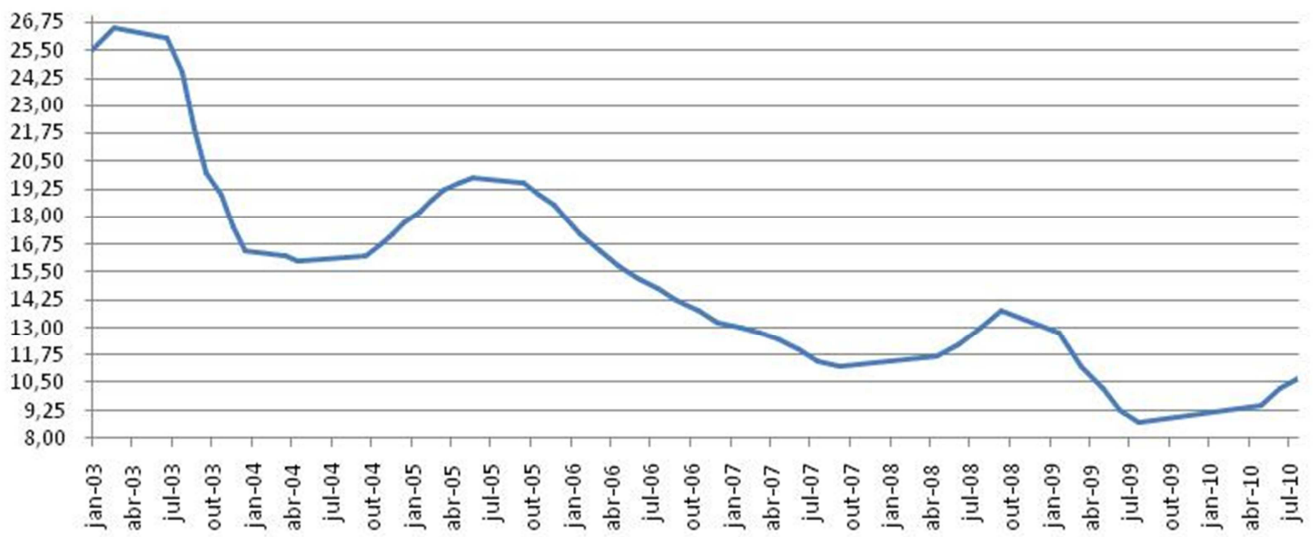

Fonte: Banco Central do Brasil.

No campo social, destaque foi dado ao Programa "Fome Zero", posteriormente "Bolsa Família", que tornou o Brasil um exportador do modelo bem-sucedido de programa de transferência condicionada de renda.

Todas essas ações repercutiram na imprensa mundial de forma contundente. ${ }^{10} \mathrm{O}$ carisma do presidente da República, que definia a si mesmo como "mascate", atraiu muita atenção e possibilitou a promoção da imagem do Brasil como um país com grande potencial e consciente de seu papel no mundo.

Dando continuidade a um movimento iniciado no governo anterior, de Fernando Henrique Cardoso (1995-2002), a política externa do Governo Lula foi orientada para a integração política com os vizinhos da América do Sul e do Caribe. Exemplo dessa articulação foi a criação da UNASUL, a partir de uma iniciativa do então presidente venezuelano Hugo Chávez. O fortalecimento do Mercosul, sobretudo no que se refere aos temas sociais e culturais, também foi um dos itens de destaque na agenda da PEB.

Em artigo sobre a política externa brasileira para a América do Sul, Saraiva (2010) observa que, desde 1991, a atuação do Brasil tem se pautado por dois movimentos, quais sejam, o processo de integração regional nos moldes do

\footnotetext{
${ }^{10}$ Em 2009, a revista "The Economist" publicou reportagem de capa intitulada "Brazil Takes Off' com a imagem do Cristo Redentor como um foguete sendo lançado. A revista destacou as oportunidades para negócios no Brasil, mas não deixou de apontar as persistentes fragilidades do País.
} 
regionalismo aberto, configurado na estruturação do Mercosul, e iniciativas de cooperação e integração com países da região. A autora aponta, ainda, que esses movimentos têm variado em função das visões de política externa de cada governo, da posição internacional do país e do comportamento dos vizinhos.

Pode-se notar uma inflexão marcante no sentido de uma maior coordenação com os países da América do Sul a partir do governo Lula. A busca pela liderança regional passou a ser um objetivo declarado de governo, que via na integração com os vizinhos

the surest route for Brazil to gain international standing, while also helping Brazil realize its potential and form a bloc that was strong enough to have more international clout. With this in mind, Brazilian diplomacy set about further developing an approach that had already begun under President Cardoso, while giving new weight to leadership building through a combination of soft power patterns, based on Grotian realism, which took the form of strengthened multilateralism in the region (SARAIVA, 2010, p. 160).

Dessa forma, o Brasil buscou ajustar o princípio da não intervenção na forma de não-indiferença e incluiu na agenda um programa de construção da liderança regional por meio da coordenação dos esforços de cooperação e integração regional com vistas a impulsionar o desenvolvimento do País (SARAIVA, 2010, p. 160).

A maioria das ações do governo Lula, a exemplo de FHC, situa-se na vertente das negociações comerciais internacionais e na busca de coordenação política com parceiros independentes do mundo desenvolvido.

Lula dá continuidade à maioria das políticas implementadas por Fernando Henrique Cardoso. Modifica, porém, a maneira de se fazer política externa, principalmente no plano regional, onde buscou assumir uma postura de liderança, tornando prioritários os projetos de integração regional. Além de atuar regionalmente, o governo Lula tem por característica a busca de parcerias com outros países emergentes, como China, Rússia, Índia e África do Sul para que juntos possam agir com mais vigor nos foros multilaterais de negociação como a Organização Mundial de Comércio (OMC). Essas iniciativas foram empreendidas de forma coerente com o entendimento de que a política externa constitui ferramenta importante na busca pelo desenvolvimento brasileiro:

A administração de Lula da Silva não se afastou do princípio historicamente assentado para a diplomacia de que a política externa é um instrumento para o desenvolvimento econômico e para a consequente preservação e ampliação da autonomia do país (VIGEVANI e CEPALUNI, 2007, p. 322). 
Para alguns autores mais entusiasmados, do ponto de vista do conteúdo, a diplomacia do governo Lula apresenta uma postura "mais assertiva, mais enfática em torno da chamada defesa da soberania nacional e dos interesses nacionais, assim como de busca de alianças privilegiadas no Sul, com ênfase especial nos processos de integração da América do Sul e do Mercosul, com reforço consequente deste no plano político" (ALMEIDA, 2004, p. 163).

Nem todos os analistas concordam com essa avaliação. Albuquerque (2005 apud SALES, 2007, p. 124) aponta que o governo Lula representa um paradoxo: no plano econômico, a ausência de mudanças substantivas em relação à política de FHC representou um distanciamento das posições historicamente defendidas pelo Partido dos Trabalhadores, ao que Albuquerque denomina de "guinada à direita". Já na política externa, em que o Brasil tem tradição de continuidade e não se esperavam muitas mudanças, houve, porém, uma "guinada à esquerda", com mudanças sensíveis de rumo em setores fundamentais como comércio e segurança (SALES, 2007, p. 124).

O diplomata Paulo Roberto de Almeida vai ao mesmo sentido e diz que a "política externa do governo Luiz Inácio Lula da Silva é, provavelmente, a vertente que mais reflete as antigas propostas e as proposições tradicionais do Partido dos Trabalhadores" (ALMEIDA, 2004, p. 162).

Almeida realizou estudo sobre o tema, em artigo de 2003, intitulado "A política internacional do Partido dos Trabalhadores (PT): da fundação à diplomacia do Governo Lula", no qual analisa as posições de política externa assumidas pelo PT e pelo candidato Luiz Inácio Lula da Silva, desde a fundação do partido, no início dos anos 1980, passando pelos pleitos de 1989, 1994 e 1998, até a eleição de Lula em 2002.

Almeida (2003) destaca os temas básicos do programa partidário e sua evolução gradual em direção a uma postura mais próxima da forma tradicional de atuação da diplomacia profissional, caracterizada pelo multilateralismo juridicista, gradualista e pacifista. Além disso, examina as principais questões da agenda diplomática brasileira, em especial as negociações econômicas e comerciais e a discussão dos limites e possibilidades de inovação nesse terreno, concluindo pela preservação das grandes linhas de continuidade na política externa brasileira no governo Lula. De acordo com o autor, a política externa proposta pelo PT resultou de um amadurecimento que tornou o discurso mais conciliador, deixando de lado antigos radicalismos.

Pode-se dizer que o PT percorreu um longo caminho na construção tentativa de um pensamento em política externa, desde as propostas de cunho 
socialista estabelecidas no início dos anos 1980 até o programa da campanha presidencial de 2002, de tom mais conciliador em relação às obrigações externas - dívida, contratos, acordos internacionais -, o que foi confirmado no primeiro pronunciamento oficial do Presidente eleito, em 28 de outubro de 2002 e novamente em seu discurso de posse, em 1ㅇ de janeiro de 2003". (...) [A] grande mudança operada nessa área foi, assim, mais no discurso e na prática dos dirigentes do Partido, agora investidos de responsabilidade governamental, do que nas grandes linhas de atuação da política externa (ALMEIDA, 2003, p. 88).

Se, em 1989, Lula se posicionava como defensor dos oprimidos da América Latina, defendendo pautas da esquerda radical, como a decretação de uma moratória unilateral da dívida externa, em 2002 o candidato do PT já se apresentou com discurso mais realista e cuidadoso, a fim de minimizar os temores de uma parcela da população quanto ao fato de que a vitória nas eleições daquele ano pudesse significar alguma ruptura indesejada. A "Carta aos Brasileiros" tem esse sentido de afirmar o respeito aos contratos e obrigações do País (ALMEIDA, 2003, p. 93) e, portanto, contribuir para tranquilizar os mercados.

Na visão de Paulo Roberto de Almeida, as diretrizes da política externa enunciada por Lula ainda candidato objetivavam a transformação do mundo e do continente sul-americano a partir de uma "alavanca diplomática", o que, segundo o autor, indicaria excesso de otimismo quanto aos limites impostos pela realidade internacional a grandes projetos de mudança no cenário externo, sobretudo vindos de um país dotado de recursos externos limitados como o Brasil.

Não obstante, da leitura do Programa Oficial do candidato, citado por Almeida (2003), depreende-se uma clara orientação para o que terminou, de fato, sendo a tônica da política externa do governo Lula: a integração da América do Sul e a aproximação com os países da América Latina:

\footnotetext{
Uma nova política externa deverá $[\ldots]$ contribuir para reduzir tensões internacionais e buscar um mundo com mais equilíbrio econômico, social e político, com respeito às diferenças culturais, étnicas e religiosas. A formação de um governo comprometido com os interesses da grande maioria da sociedade, capaz de promover um projeto de desenvolvimento nacional, terá forte impacto mundial, sobretudo em nosso Continente. Levando em conta essa realidade, o Brasil deverá propor um pacto regional de integração, especialmente na América do Sul. Na busca desse entendimento, também estaremos abertos a um relacionamento especial com todos os países da América Latina (PROGRAMA OFICIAL DO CANDIDATO LULA, 2002 apud ALMEIDA, 2003).
}

Insta destacar, que, também em 2002, foi divulgada a "Carta aos brasileiros longe de casa", na qual o então candidato Lula incorporava à sua plataforma de 
campanha um conjunto de propostas para os cidadãos brasileiros vivendo no exterior, como a melhora do atendimento consular, a redução da taxa cobrada sobre remessas para o Brasil, a criação de organismos de representação dos emigrantes junto aos Consulados e Embaixadas, e, principalmente,

[b]uscar ampliar e garantir a efetivação de acordos bilaterais entre o Brasil e os países de acolhimento, com o objetivo de assegurar o atendimento das necessidades de nossos compatriotas, concernentes à Seguridade Social, reconhecimento de títulos ou de equivalência na educação média e superior, atendimento no sistema de saúde etc. (LULA DA SILVA, 2002).

Em que pese o fato de a manifestação do PT com relação aos brasileiros no exterior corresponder a uma estratégia voltada à sensibilização de potenciais eleitores, conforme apontado por Reis $(2011)^{11}$, trata-se de uma inflexão importante na política externa para as migrações e que deixa de ser comentado por Almeida (2003). Essa omissão pode ser creditada ao fato de que, conforme referido na introdução deste trabalho, o tema das migrações ainda é marginal na literatura sobre política externa brasileira.

As impressões consignadas por Paulo Roberto de Almeida no supramencionado artigo de 2003 se repetem em texto de 2004. O autor reitera que o discurso partidário em temas de política internacional comanda a ação governamental e constitui o eixo da política do governo Lula que mais se aproxima das formulações originais do PT. No plano diplomático e econômico, observa-se postura essencialmente crítica à globalização e à abertura comercial. Para o governo Lula, as relações com o FMI e o Banco Mundial serão mantidas apenas enquanto forem estritamente necessárias. Almeida (2004) assim resume a atuação política da chancelaria de Lula:

\begin{abstract}
No plano político, é evidente o projeto de reforçar a capacidade de 'intervenção' do Brasil no mundo, a assunção declarada do desejo de ocupar uma cadeira permanente num Conselho de Segurança reformado e a oposição ao unilateralismo ou unipolaridade, com a defesa ativa do multilateralismo e de um maior equilíbrio nas relações internacionais. No plano econômico, trata-se de buscar maior cooperação e integração com países similares (outras potência médias) e vizinhos regionais (ALMEIDA, 2004, p. 165).
\end{abstract}

\footnotetext{
${ }^{11}$ De fato, o número de eleitores habilitados a votar para presidente nas representações do Brasil no exterior aumentou expressivamente: o quantitativo passou de 69.797 eleitores em 93 países $(0,05 \%$ do eleitorado total), em 2002, para 199,795 pessoas (0,14\% do eleitorado) em 113 países em 2010 (aumento de 186,25\%). Considerando os dados de 2014, a expansão é ainda mais significativa: o quantitativo teve acréscimo de $77 \%$ em relação a 2010, totalizando 353.821 eleitores (aumento de $407 \%$ em relação a 2002), passando a representar $0,25 \%$ do eleitorado total. Fonte: TSE.
} 
Para Vigevani e Cepaluni (2007), a política externa de Lula se insere na estratégia de "autonomia pela diversificação", que consiste na adesão do país aos princípios e às normas internacionais por meio de alianças sul-sul, inclusive regionais, e de acordos com parceiros não tradicionais (China, Ásia-Pacífico, África, Europa Oriental, Oriente Médio etc.), pois acredita-se que eles reduzem as assimetrias nas relações externas com países mais poderosos e aumentam a capacidade negociadora nacional.

Conforme Cardozo e Miyamoto (2006, p. 3 apud VIGEVANI e CEPALUNI, 2007, p. 290), algumas diretrizes do "Pragmatismo Responsável” de Geisel (1974-1978) são retomadas pela política externa do governo Lula, tais como, afirmar autonomia em relação às grandes potências e ampliar laços com países do Sul, tanto bilateralmente como em instituições internacionais. Em linhas gerais, as mudanças tiveram como diretrizes: i) contribuir para a busca de maior equilíbrio internacional, procurando atenuar o unilateralismo; ii) fortalecer relações bilaterais e multilaterais de forma a aumentar o peso do país nas negociações políticas e econômicas internacionais; iii) adensar relações diplomáticas no sentido de aproveitar as possibilidades de maior intercâmbio econômico, financeiro, tecnológico, cultural etc.; e iv) evitar acordos que possam comprometer a longo prazo o desenvolvimento. Essas diretrizes, ao longo do primeiro mandato, de 2003 a 2006, provavelmente desdobrando-se no segundo, implicaram ênfases precisas: i) aprofundamento da Comunidade Sul-americana de Nações (posteriormente convertida no processo da UNASUL); ii) intensificação das relações entre países emergentes como Índia, China, Rússia e África do Sul; iii) ação de destaque na Rodada Doha e na Organização Mundial do Comércio, assim como em algumas outras negociações econômicas; iv) manutenção de relações de amizade e desenvolvimento das relações econômicas com os países ricos, inclusive com os Estados Unidos; v) retomada e estreitamento das relações com os países africanos; vi) campanha pela reforma do Conselho de Segurança das Nações Unidas, visando um lugar de membro permanente para o Brasil; e vii) defesa de objetivos sociais que permitiriam maior equilíbrio entre Estados e populações (VIGEVANI e CEPALUNI, 2007),

Conforme anteriormente mencionado, em comparação com o período FHC, a administração de Lula também não se afastou do princípio historicamente assentado para a diplomacia de que a política externa é um instrumento para o desenvolvimento econômico e para a consequente preservação e ampliação da autonomia do país. No 
campo dos valores, conforme as diretrizes subjacentes à ideia da "autonomia pela participação", FHC defendeu princípios de direitos humanos e formas de desenvolvimento sustentáveis, procurou preservar a paz e a democracia, buscando objetivos "universalistas", como uma maior institucionalização, maior transparência nas decisões e uma crescente democratização das organizações e regimes internacionais Para o grupo formulador da política externa no governo FHC, o eventual papel do Brasil como líder era visto como consequência da gradual proeminência econômica do país e deveria ser limitado à região, por causa da escassez de recursos (financeiros, bélicos, políticos e de quadros profissionais) disponíveis para a ação externa do Estado. Os formuladores da política externa do governo Lula da Silva, por sua vez, acreditavam que o papel de liderança poderia ser alcançado por meio de uma ação diplomática mais ativa e dinâmica, assim como da continuidade da defesa de temas "universais".

Subjacentes a essas iniciativas, encontram-se alguns princípios e orientações que constituem o que Cervo (2008, p. 26 e ss.) identifica como o "acumulado histórico da diplomacia brasileira": o multilateralismo, o respeito ao direito internacional, além de outros importantes padrões de conduta da PEB, tais como, a não indiferença, a solidariedade e, a partir de Lula, a ênfase na cooperação sul-sul.

Nas seções a seguir, analisaremos cada uma dessas características, a fim de por em relevo aspectos importantes da PEB que constituem elementos-chave para a análise de sua execução no período e que, em nosso entendimento, exerceram influência marcante sobre as relações internacionais brasileiras e tiveram impacto sobre a política migratória brasileira.

\subsection{Multilateralismo}

O multilateralismo integra há décadas a política externa brasileira, motivada por expectativas acerca de seu alcance para realizar interesses do desenvolvimento e das relações internacionais do País; padrão de qualidade da política multilateral formulada pelos governos brasileiros; e experiência contínua da diplomacia nos órgãos multilaterais (CERVO, 2008, p. 94). Cervo (2008) destaca que, no final do século XIX, o Brasil já participava como membro fundador ou parte na maioria dos principais organismos multilaterais constituídos para tratar de questões técnicas como transportes e comunicações. Em outras instâncias de caráter político, teve atuação destacada na II Conferência Internacional da Paz, realizada na Haia em 1907. A participação na I 
Guerra Mundial garantiu a presença brasileira na Conferência de Paz de Versalhes, em 1919, que instituiu a Liga das Nações.

A partir desse momento, a atuação do Brasil foi orientada por dois parâmetros: prioridade à participação na criação das regras internacionais, valorizando o marco jurídico-legal e entendendo que o país não poderia deixar de ser parte constitutiva desses processos; e ao mesmo tempo, evitar que as normas multilaterais, refletindo interesses dos Estados mais poderosos, pudessem impor limitações à margem de manobra e escolhas futuras do País (MELLO, 2012).

O objetivo do Brasil é, portanto, conjugar o compromisso com o fortalecimento do multilateralismo e a preservação da autonomia nacional. Apresentar-se como mediador entre as grandes potências e os demais membros do sistema, assumindo posição de defesa dos direitos dos países menores, mas, ao mesmo tempo, pleiteando reconhecimento equivalente ao das grandes potências, tornou-se um padrão de inserção em foros multilaterais (LIMA, 2005; MELLO, 2012).

Esse padrão apresenta-se como uma combinação heterodoxa entre a defesa de uma ordem internacional menos desigual (visão idealista) e posições pragmáticas de aceitação da hierarquia do sistema internacional (visão realista). Essa atuação como mediador entre fortes e fracos implica "lidar permanentemente com a dissonância entre os objetivos particulares, voltados para a sua inserção individual entre as potências, e os objetivos coletivos dos demais países que o mediador supostamente representaria no sentido da promoção do universalismo no acesso aos espaços decisórios" (MELLO, 2012). Para Cervo (2008, p. 94), podem ser indicadas quatro fases do multilateralismo brasileiro, com objetivos e resultados distintos, ligados às expectativas criadas a seu respeito, sendo: i) a contribuição do Brasil à construção do sistema internacional do pós-guerra, entre 1944 e 1949; ii) o esforço de reforma da ordem internacional, dos anos 1960 aos 1980; iii) a perspectiva de atuar no sistema em vez de reformá-lo, que se vislumbra entre 1990 e 2002; e iv) o objetivo de estabelecer a reciprocidade entre estruturas hegemônicas e países emergentes, de 2003 ao presente.

Cervo (2008, p. 114) assinala que a análise dessas quatro fases da política multilateral revela que não houve uniformidade de apreciação nem linearidade de conduta por parte dos dirigentes brasileiros. $\mathrm{O}$ autor reconhece que, ao longo do tempo, a avaliação teria sido positiva, mas observa que a bipolaridade prevaleceu sobre os multilateralismos desde o fim dos anos 1940, com a divisão ideológica e o combate ao comunismo, sem que tal ascendência trouxesse vantagens ao desenvolvimento, como 
ocorrera com a divisão do mundo em blocos antagônicos no contexto da Segunda Guerra Mundial.

Para Vigevani e Cepaluni (2007, p. 300), o governo FHC caracterizou-se pelo multilateralismo, atribuindo ênfase ao direito internacional, principalmente na gestão do ministro Celso Lafer, fiel à tradição diplomática brasileira, que sempre buscou utilizar os argumentos por ele fornecidos.

A opção pelo multilateralismo é característica da política externa de uma potência emergente que reconhece suas limitações em termos de recursos de poder e defende seus interesses privilegiadamente, seja pela via institucional, seja pela participação em organizações internacionais, seja, ainda, pela sua inclusão em regimes internacionais (MELLO, 2012). Isso explica o empenho do Brasil pela participação em arranjos coletivos inovadores que permitam ampliar sua margem de manobra nas instâncias internacionais, como o IBAS (Índia-Brasil-África do Sul) e o BRICS (Brasil, Rússia, Índia, China e África do Sul), ou ainda a UNASUL (União das Nações SulAmericanas) no plano regional, a fim de potencializar sua inserção internacional.

Atuando em prol da reforma do sistema global, o Brasil se posiciona ao lado dos emergentes na busca por maior espaço de atuação nos foros de governança, como as Nações Unidas.

\subsection{Respeito ao direito internacional}

Os tratados são compreendidos como fator de estabilização das relações internacionais. Esse comportamento se mantém desde que o Brasil firmou, à época da Independência, duas dezenas de tratados desiguais com as potências capitalistas de então e desde que, posteriormente, firmou com os vizinhos outros tantos com o fim de garantir o território e a paz. O professor Antonio Jorge Ramalho da Rocha aponta que o Brasil mantém essa tradição de respeito aos instrumentos de Direito Internacional, na medida em que essa postura contribui para a preservação um princípio caro ao Brasil, qual seja, a autodeterminação dos povos.

O respeito ao compromisso jurídico internacional, assumido sob as formas de tratado, convenção, protocolo e outros, envolve a soberania e assegura a autodeterminação dos povos. O Brasil tradicionalmente mantém uma política externa que defende não apenas um mundo governado por regras, mas, pelo menos desde ao anos 1960, a promoção da justiça e da igualdade no âmbito internacional (ROCHA, 2006, p. 104). 
Rocha (2006) aponta um paradoxo quanto ao fato de que o Brasil entende como legítima a liderança que busca exercer, enquanto a percepção, por parte de outros países, é de que o País poderia representar uma ameaça. A imposição da liderança é frequentemente caracterizada como uma tentativa de dominação, apenas como mais uma manifestação de imperialismo (ROCHA, 2006, p. 110). Essa constatação levou o Brasil a apresentar-se, ao longo da História, como um Estado que sempre defendeu a justiça e o Direito Internacional. A solução negociada de fronteiras com outros dez países e a inexistência de conflitos bélicos com os vizinhos há mais de 150 anos são temas constantemente presentes nos discursos diplomáticos.

Em linha com a tradição juridicista, o Brasil aderiu aos principais instrumentos internacionais que versam sobre direitos humanos. Com relação aos refugiados, o país é signatário da Convenção das Nações Unidas de 1951 sobre o Estatuto dos Refugiados e de seu Protocolo de 1967 e da Convenção das Nações Unidas de 1954 sobre o Estatuto dos Apátridas. Em 1998, reconheceu a jurisdição obrigatória da Corte Interamericana de Direitos Humanos. Em 2004, assinou a Convenção Internacional sobre a Proteção dos Direitos de Todos os Trabalhadores Migrantes e dos Membros das suas Famílias, adotada pela Resolução 45/158 da Assembleia-Geral das Nações Unidas, de 18 de dezembro de 1990, embora ainda não a tenha ratificado.

Essas ações demonstram a preocupação da política externa brasileira com os temas de direitos humanos e o reconhecimento da necessidade de incorporação da temática das migrações e do refúgio em instrumentos de Direito Internacional.

\subsection{Solidariedade e não indiferença}

Prevalece no discurso oficial a visão do Brasil como "uma nação de crescimento econômico com inclusão social crescente, em que a redução progressiva das desigualdades e o compromisso comum com a plena vigência da democracia convivem e se reforçam mutuamente" (IPEA, 2010, p. 9). As políticas públicas de redução das desigualdades de renda e promoção de oportunidades têm sido apontadas como elementos que explicam a migração de milhões de brasileiros do nível de pobreza extrema para a classe média.

Ainda que os desafios da inclusão social não estejam superados, o Brasil tem demonstrado disposição para se desenvolver e contribuir para o progresso social e econômico de outros povos. Nesse sentido, pode-se dizer que essas ações são 
empreendidas com espírito de solidariedade. $\mathrm{O}$ envolvimento brasileiro no alcance dos Objetivos do Milênio, a partir do compartilhamento de conhecimentos, experiências bem-sucedidas e oferta de insumos de diferentes naturezas, é exemplo dessa atitude.

Em razão do saber acumulado e de experiências disponíveis em inúmeras instituições nacionais, bem como à luz da capacidade brasileira de replicar as boas práticas para enfrentar problemas que se reproduzem em outros países em desenvolvimento, a cooperação horizontal brasileira tem demonstrado resultados positivos no apoio à correção de assimetrias sociais e econômicas presentes em outras nações. As diretrizes da atuação do Brasil em diferentes modalidades de intercâmbio internacional foram construídas e são aplicadas a partir de uma diplomacia independente, sem subserviência e respeitosa de seus parceiros. Segundo o ex-ministro das Relações Exteriores do Brasil, embaixador Celso Amorim, o país é hoje caracterizado por uma diplomacia inovadora, mas que não se afasta dos valores fundamentais da nação brasileira - a paz, o pluralismo, a tolerância e a solidariedade (AMORIM, 2010, p. 5).

\subsection{Cooperação Sul-Sul}

Outra vertente importante da projeção internacional do Brasil no período analisado por esta dissertação se deu pela via da cooperação internacional. Sob o argumento de que "em um mundo cada vez mais interdependente, a paz, a prosperidade e a dignidade humana não dependem apenas de ações em âmbito nacional e a cooperação para o desenvolvimento internacional é peça-chave para o estabelecimento de uma ordem internacional mais justa e pacífica" (IPEA, 2010, p. 7), o Brasil buscou apoiar outros países emergentes na superação de seus obstáculos ao desenvolvimento.

Em sentido amplo, a expressão "cooperação internacional” pode aludir a políticas de aproximação com outros países, tanto no nível bilateral, como, especialmente, no multilateral (IGLESIAS PUENTE, 2010, p. 223). Nesse caso, significa expressão de diálogo e coordenação em temas como a agenda econômica multilateral e a integração regional. Como exemplos, poderiam ser citadas as iniciativas brasileiras para as negociações comerciais multilaterais, como a formação do G- $20^{12}$ às

\footnotetext{
${ }^{12}$ Formado por iniciativa do Brasil, o G-20 “comercial” é um agrupamento informal composto por países emergentes interessados na eliminação de subsídios e subvenções às exportações de produtos agrícolas e em um maior acesso aos mercados dos países desenvolvidos. (ALMEIDA, 2004, p. 166). O número de
} 
vésperas da reunião ministerial da OMC em Cancún, no México, e do Fórum de Diálogo IBAS, com África do Sul e Índia, e para a integração, a partir da conformação, em 2004, da CASA (Comunidade Sul-Americana de Nações), posteriormente UNASUL (União de Nações Sul-Americanas), em 2007.

Por outro lado, a cooperação internacional também pode ocorrer no contexto específico da cooperação técnica e científica, tanto em âmbito bilateral como multilateral. Segundo definição da Agência Brasileira de Cooperação (ABC) do Ministério das Relações Exteriores, a cooperação pode ser vertical ou recebida, nos casos em que países desenvolvidos articulam projetos de capacitação técnica para o Brasil, a partir da convergência entre os aportes técnicos disponibilizados por organismos internacionais (cooperação multilateral) e por países mais desenvolvidos (cooperação bilateral), com as capacidades humanas e institucionais presentes nas instituições brasileiras; e horizontal ou prestada, quando é o Brasil que compartilha experiências e conhecimentos disponíveis em instituições brasileiras junto a instituições de países em desenvolvimento (ABC, 2015).

Conforme a posição oficial, a cooperação técnica prestada pelo Brasil permite promover o adensamento de relações com os países interessados em distintas dimensões, dentro do marco de uma política externa solidária no campo da Cooperação para o Desenvolvimento. Essa cooperação é realizada em resposta a demandas de países em desenvolvimento (demand-driven), reconhecimento da experiência local, nãoimposição de condicionalidades, não-vinculação a interesses comerciais ou fins lucrativos e não-ingerência em assuntos internos dos países parceiros (ABC, 2015).

Em tese apresentada ao Curso de Altos Estudos do Instituto Rio Branco (IRBr/MRE), o diplomata Carlos Alfonso Iglesias Puente analisa a cooperação técnica horizontal brasileira como instrumento de política externa, abordando sua evolução no período de 1995-2005. Para o autor, a Cooperação Técnica entre Países em Desenvolvimento (CTPD) constitui um dos meios com que conta o Brasil para se afirmar no cenário internacional (IGLESIAS PUENTE, 2010, p. 32). Ao longo do trabalho, fica evidenciado que, ressalvadas as deficiências no processo de planejamento e avaliação apontadas pelo autor (2010, p. 254), a cooperação tem sido exitosa em seus objetivos de i) propiciar efetivas contribuições para o progresso dos países parceiros no caminho do desenvolvimento; ii) prestar real contribuição para o adensamento das 
relações entre o Brasil e os países parceiros, em vários campos; e iii) contribuir para a projeção internacional do Brasil, sobretudo, mas não apenas, como ator relevante nos esforços de cooperação sul-sul, mas também de aportes à construção e reforço da legitimidade, credibilidade e liderança do País (IGLESIAS PUENTE, 2010, p. 253). Nesse último item, na visão do autor, a CTPD tem representado

\begin{abstract}
uma ferramenta utilizada pelo Brasil na promoção da estabilidade política e institucional de países em desenvolvimento que passaram por crises políticas. Tanto no caso de vizinhos (Bolívia, Paraguai, Equador), como junto a países não tão próximos geograficamente (Timor-Leste, Haiti, Guiné-Bissau, São Tomé e Príncipe, para citar alguns exemplos). Trata-se de esforço significativo de promoção não somente de desenvolvimento econômico e social, mas com consequências sobre os objetivos gerais de pacificação e de estabilização política (2010, p. 259).
\end{abstract}

A cooperação técnica brasileira em sua vertente horizontal cresceu e se diversificou na década passada, em grande parte motivada pelo sucesso das políticas sociais implementadas pelo Brasil e que se tornaram "objeto de desejo" de outros países em desenvolvimento.

A Cooperação Brasileira para o Desenvolvimento Internacional tem sido
movida por princípios alinhados às visões de relações equânimes e de justiça
social, constituindo-se em importante instrumento de política externa. De
fato, o Brasil acumulou significativos resultados na implementação de suas
políticas sociais. À medida que estas se ampliavam e se consolidavam
internamente, o governo recebia crescentes pedidos para compartilhar suas
experiências e boas práticas com países parceiros. A repercussão positiva
dessas políticas, por sua vez, garantiu ao Brasil crescente reconhecimento
internacional, consolidado, sobretudo, ao longo da primeira década do século
XXI (IPEA, 2010, p. 16).

Entre os principais setores de cooperação técnica internacional prestada pelo Brasil encontram-se agropecuária, saúde, meio ambiente, recursos naturais, educação, administração pública e finanças, desenvolvimento social, formação profissional, energia e bicombustíveis. Destes, destacam-se alguns campos em que o Brasil atingiu reconhecida excelência, tais como, a agropecuária (atuação da EMBRAPA e outras congêneres compartilhando tecnologia de cultivo, erradicação e controle de enfermidades e pragas para aumento da produtividade agrícola e pecuária dos países parceiros), saúde (ações da Fiocruz na área de DST/HIV/AIDS e imunização, combate a doenças tropicais e outras endemias, e da ANVISA em vigilância sanitária) e desenvolvimento social (programas de inclusão social como Bolsa Família e atividades na área de promoção de direitos humanos) (IGLESIAS PUENTE, 2010, p. 162 e ss.).

Segundo o Instituto de Pesquisa Econômica e Aplicada (IPEA), a cooperação brasileira para o desenvolvimento internacional pode ser definida como 
a totalidade de recursos investidos pelo governo federal brasileiro, totalmente a fundo perdido, no governo de outros países, em nacionais de outros países em território brasileiro, ou em organizações internacionais com o propósito de contribuir para o desenvolvimento internacional, entendido como o fortalecimento das capacidades de organizações internacionais e de grupos ou populações de outros países para a melhoria de suas condições socioeconômicas (IPEA, 2010, p. 11).

Em 2010, o IPEA realizou um estudo sobre a cooperação sul-sul entre os anos de 2005 e 2009. O documento lista as principais iniciativas empreendidas pelo governo brasileiro em 5 linhas de ação, a saber: i) assistência humanitária; ii) bolsas de estudo para estrangeiros; iii) cooperação técnica, científica e tecnológica; iv) contribuições a organizações internacionais e bancos regionais; e v) operações de paz.

Conforme tabelas elaboradas por Iglesias Puente (2010) a partir de dados obtidos em pesquisa junto à $\mathrm{ABC} / \mathrm{MRE}$, combinados com informações extraídas de relatórios do IPEA, o total dos recursos investidos apenas em cooperação técnica alcança aproximadamente R \$ 367 milhões entre 2003 e 2010. Em comparação com o período de 1995-2002, no qual o valor totalizou R \$ 8,5 milhões, observa-se expressivo incremento nos gastos com cooperação técnica durante o Governo Lula.

Tabela 1. Gastos com cooperação técnica (1995-2010) - em R \$ mil

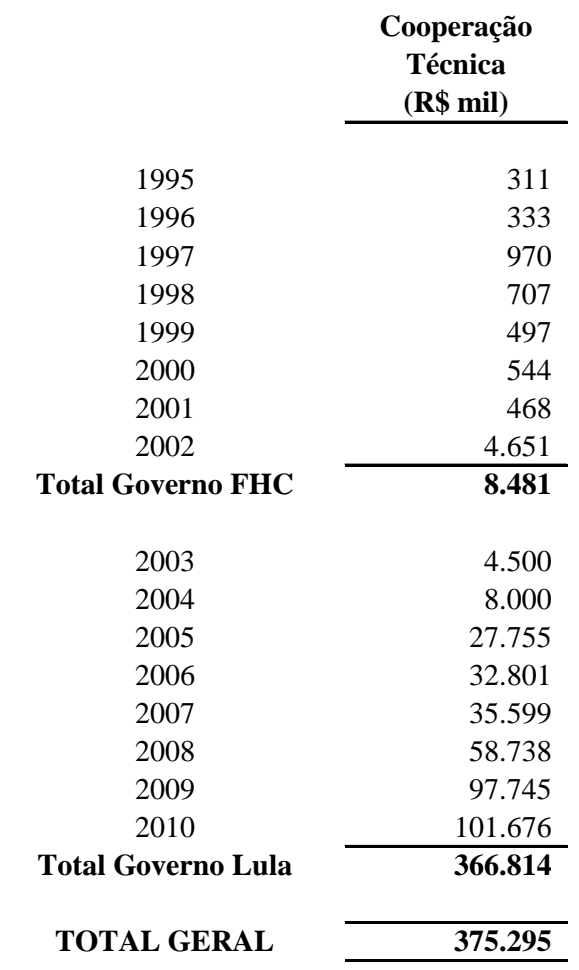

Fonte: Iglesias Puente (2010) e IPEA (2010).

Em termos de distribuição de recursos por regiões, observa-se que, embora a cooperação prestada aos países da América Latina e Caribe tenha permanecido 
substancial (acima de 60\%) nos dois governos analisados, no governo FHC o foco maior é sobre os países africanos de língua oficial portuguesa (PALOP) e Timor-Leste, e, no governo Lula, a atenção se estende a outros países africanos além dos PALOPS e ao Haiti, em especial (IGLESIAS PUENTE, 2010, p. 270). Quando se consideram todas as linhas de ação, o valor atinge a cifra de R \$ 5,1 bilhões entre 2005 e 2010.

Tabela 2. Gastos com a Cooperação Internacional (2005-2010) - em R\$ mil

\begin{tabular}{|c|c|c|c|c|c|c|c|}
\hline & 2005 & 2006 & 2007 & 2008 & 2009 & 2010 & TOTAL \\
\hline Bolsas de estudo para estrangeiros & 56.104 & 56.455 & 56.377 & 70.667 & 44.474 & 62.558 & 346.635 \\
\hline Cooperação humanitária* & 1.185 & 5.524 & 31.805 & 29.745 & 87.042 & 285.226 & 440.527 \\
\hline Contribuições para organizações internacionais & 299.146 & 509.534 & 445.422 & 457.249 & 495.159 & 548.362 & 2.754 .872 \\
\hline Operações de manutenção da paz & 147.793 & 80.709 & 131.773 & 127.919 & 125.409 & 585.063 & 1.198 .666 \\
\hline
\end{tabular}

Com relação às organizações internacionais, as maiores contribuições foram realizadas ao Mercosul e à ONU, e, quanto às operações de manutenção da paz, a MINUSTAH, missão de estabilização da paz no Haiti, cuja vertente militar é liderada pelo Brasil, recebeu a maior parte dos recursos (cerca de $\mathrm{R} \$ 467$ milhões em 2010, ou $80 \%$ do montante empregado naquele ano), em razão do terremoto que atingiu o país caribenho em janeiro daquele ano (IPEA, 2011, p. 86).

Conclui-se, portanto, com a afirmação de que tanto no governo FHC, quanto no governo Lula, a cooperação internacional, como parte integrante da cooperação sul-sul, foi empregada como instrumento de política externa com vistas a projetar o Brasil no mundo e contribuir para o desenvolvimento internacional. Essa constatação vem ao encontro do argumento central defendido por este trabalho, de que essa maior presença do Brasil e a exposição das políticas públicas nacionais exitosas em países africanos e caribenhos, como o Haiti, incluiu o Brasil no rol de possibilidades para os migrantes internacionais que buscam melhores condições de vida e que, por isso, é preciso entender a dinâmica entre a política externa e a política migratória no Brasil, de forma a potencializar as vantagens e minimizar as desvantagens das migrações para a inserção internacional do País e para a gestão do fenômeno migratório em nível doméstico.

Em seguimento a essa ideia, discutiremos as principais teorias migratórias e apresentaremos os fluxos migratórios contemporâneos. 


\section{Capítulo 2: Migrações contemporâneas}

A análise das políticas externas de Fernando Henrique Cardoso e Luiz Inácio Lula da Silva permitiu observar que, em que pesem as suas (muitas) diferenças de foco e ênfase, operando em contextos políticos e econômicos bastantes diversos, ambas buscaram a inserção internacional autônoma do Brasil e se mantiveram fiéis às tradições que Cervo (2008, p. 26 e ss.) classifica como "o acumulado histórico da diplomacia brasileira", tais como, o multilateralismo, o respeito ao direito internacional, bem com outros importantes padrões de conduta da PEB: a não indiferença, a solidariedade e a cooperação internacional.

Partindo da premissa de que esses parâmetros foram fundamentais para a formulação da PEB no período, torna-se necessário apresentar referencial teórico e considerações de ordem quantitativa e qualitativa que permitirão uma melhor compreensão das migrações internacionais e possibilitarão as análises das eventuais influências da política externa na política migratória praticada pelo Brasil entre os anos de 1995 e 2010, a serem desenvolvidas no capítulo 3.

Na primeira seção, serão abordadas as principais teorias explicativas sobre as migrações internacionais, enfocando-se a sua diversidade e discutindo-se as dificuldades que os teóricos ainda encontram para obter uma síntese que elucide os principais questionamentos que envolvem o tema. Em seguida, será exposto um breve histórico das migrações no Brasil, a fim de se observar os fluxos tradicionais e a dinâmica dos mais recentes à luz de seu comportamento durante o período de que trata a pesquisa.

A terceira seção abordará a evolução da legislação migratória, discutindo-se a crítica ao Estatuto do Estrangeiro de 1980 e as medidas paliativas que têm sido implementadas para avançar rumo à atualização do aparato normativo enquanto uma reformulação geral da legislação não se concretiza. A quarta seção tratará da atuação dos órgãos de governo envolvidos na política migratória, enfocando as atribuições e os posicionamentos de representantes envolvidos na formulação e execução dessa política. Por fim, na quinta seção, comenta-se o debate contemporâneo sobre as adaptações necessárias às políticas públicas para aprimorar a gestão das migrações no Brasil.

Antes de aprofundar o debate sobre o tema, contudo, cabe contextualizá-lo. 
A Declaração Universal dos Direitos Humanos, de 1948, reconhece, em seu art. 13, parágrafo $2^{\circ}$, o direito à mobilidade internacional: "Toda pessoa tem o direito de deixar qualquer país, inclusive o próprio, e a este regressar". Apesar de sua força simbólica como enunciadora de direitos em um mundo que se recuperava da calamidade da Segunda Guerra Mundial e da influência exercida sobre os ordenamentos jurídicos de muitas nações que a subscreveram, a Declaração não possui caráter vinculante. Firmouse, entre os especialistas em Direito Internacional, o entendimento de que as proposições nela contidas são princípios orientadores da conduta dos Estados, mas estes não são obrigados a portar-se de acordo com suas disposições.

O citado artigo visa assegurar ao indivíduo a liberdade de deixar seu país de origem a qualquer tempo e a ele regressar, sem que disso seja impedido pelo Estado. Dotado de uma nacionalidade, direito universal também conferido pelo Art. 15, § 1ㅇ da Declaração, esse indivíduo detém a prerrogativa de cruzar a fronteira de seu país em direção a outro no qual será considerado não nacional ou estrangeiro.

Entretanto, é forçoso reconhecer que, embora o direito de deixar um território nacional de origem esteja consignado na Declaração, não há nada que obrigue o país de destino a receber o estrangeiro. O Estado é uma entidade dotada de soberania, com poder para estabelecer sob quais condições um indivíduo que detenha outra nacionalidade que não a sua poderá nele ingressar e por quanto tempo poderá permanecer sob sua jurisdição. Decorre da soberania estatal a prerrogativa de definir critérios para admissão e controle do fluxo de ingresso de estrangeiros em um dado território nacional, e esses critérios conformam a política migratória em sentido amplo.

O conceito de soberania estatal, porém, vem enfrentando um processo contínuo de relativização. O reconhecimento da dignidade da pessoa humana e a extensão do conceito de cidadania para além da nacionalidade são consequências diretas do fenômeno de "internacionalização dos direitos humanos". Enquanto a Declaração Universal dos Direitos Humanos possui caráter programático, as convenções e os tratados internacionais que versam sobre a matéria de fato criam obrigações e orientam a conduta dos entes estatais. Esse conjunto normativo tem, portanto, papel fundamental na maneira como os Estados se posicionam em relação aos fluxos migratórios. O tratamento conferido aos não nacionais, para além dos procedimentos burocráticos de admissão e permanência no território, que envolve a observância dos princípios relativos aos direitos humanos por um Estado, constitui a política migratória em sentido estrito. 
Para o Ministério do Trabalho, imigrante é todo aquele que deixa seu Estado de origem, com o qual detém vínculos decorrentes de sua nacionalidade, para estabelecerse em outro em caráter permanente (BRASIL, 2010a). No país receptor, todo não nacional é denominado estrangeiro, mas somente será considerado imigrante aquele que desejar se fixar naquele território. Sendo assim, um indivíduo que visita um país por um período de tempo determinado, ainda que prolongado, não é considerado imigrante. Para Lopes (2009, p.32), o termo 'imigrante' indica “movimento, ação, muito embora a condição de imigrante permaneça após concluído o ato de imigrar". Assim, seu conteúdo expressa uma situação social, enquanto o termo 'estrangeiro' estaria mais vinculado a uma situação jurídica. Nesse sentido, a autora caracteriza o imigrante como “o estrangeiro que permanece” (LOPES, 2009, p.32). Já para Sayad (1998, p. 243), se "estrangeiro" é a definição jurídica de um estatuto, "imigrante" é antes de tudo uma condição social.

Os motivos que levam alguém a migrar podem variar desde uma busca voluntária por melhores condições de vida, oportunidades de trabalho e estudo, identificação com a cultura do país receptor, reunião familiar com outros indivíduos de sua nacionalidade, isto é "razões de conveniência pessoal" (OIM, 2009, p. 43), até a busca por refúgio, em função de perseguição política, étnica ou religiosa, com fundados temores de perseguição que possam constituir ameaça à sua vida, sendo esse perigo tão iminente que o impeça de retornar. A migração forçada também pode ocorrer em função de desastres naturais e catástrofes ambientais. O Brasil tem recebido número cada vez maior de pedidos de refúgio. ${ }^{13}$

As análises conduzidas ao longo deste trabalho tratarão prioritariamente das migrações voluntárias, assim consideradas quando o indivíduo deixa o país natal por alguma das razões de conveniência pessoal apontadas acima. Não obstante, cabe assinalar que o instituto de refúgio tem legislação específica e consolidada no Brasil (Lei no 9.474, de 1997), a partir da adesão do país às principais convenções internacionais que tratam do tema (Convenção das Nações Unidas de 1951 sobre o Estatuto dos Refugiados e seu Protocolo de 1967; Convenção das Nações Unidas de 1954 sobre o Estatuto dos Apátridas; Convenção da ONU de 1961 para Redução dos Casos de Apatridia, esta em processo de adesão (ACNUR, 2014). O contingente de

\footnotetext{
${ }^{13}$ Segundo o ACNUR (2014), foram 566 pedidos em 2010, 1.138 em 2011, 2.008 em 2012, $5.882 \mathrm{em}$ 2013 e 8.302 até outubro de 2014.
} 
refugiados ainda é muito pequeno em relação ao número de estrangeiros - apenas 5.208 ao final de 2013, de 80 nacionalidades (ACNUR, 2014) em um universo de cerca de 1,5 milhão de imigrantes legalizados (EBC, 2014).

O tema envolve ações de cooperação com organizações internacionais, como o ACNUR, e demanda respostas do Estado brasileiro no acolhimento aos refugiados. Cabe registrar, porém, que já existem diversos trabalhos sobre refúgio na esfera dos direitos humanos, enquanto uma parcela substancialmente menor de pesquisadores se dedica às migrações em sentido amplo e à análise das políticas migratórias como resultado das ações de política externa.

A seguir, serão descritas algumas correntes teóricas relativas às migrações internacionais que buscam explicar os motivos pelos quais as migrações têm início e se mantêm ao longo do tempo e que podem fornecer elementos importantes para compreender o fenômeno e as políticas migratórias produzidas a partir desses estudos.

\subsection{Teorias explicativas sobre as migrações internacionais}

Com The Laws of Migration, o geógrafo alemão Ernst Georg Ravenstein inaugurou os estudos teóricos baseados no cálculo racional sobre a decisão de migrar. Em artigos publicados no Journal of the Statistical Society of England em 1885 e 1889, Ravenstein procurou identificar, a partir de informações dos censos demográficos do Reino Unido de 1871 e 1881, padrões que pudessem explicar e prever migrações internas e entre países (CORBETT, 2011).

Os conceitos de absorção e dispersão são centrais na formulação do modelo de Ravenstein, sendo o primeiro referente a um país no qual se verifica saldo migratório positivo (o número de pessoas que entrou é maior do que o número de pessoas que deixou o país); o segundo, aos casos em que se verifica saldo migratório negativo (o número de pessoas que saiu é maior do que o número de pessoas que ingressou no país). Suas ideias foram criticadas à época, com o argumento de que identificar padrões não poderia ser comparado a encontrar leis "naturais" para explicar o fenômeno. Mais tarde, outros autores expandiram algumas de suas ideias e desenvolveram modelos de análise que levam em consideração fatores de atração (pull) e repulsão (push) para explicar os fluxos migratórios (CORBETT, 2011). 
Segundo Massey et al. (1993), existem duas categorias de abordagens teóricas de migração internacional: as que explicam o início da migração e as que tratam da persistência dos movimentos migratórios no espaço e no tempo. Na primeira categoria, incluem-se a teoria econômica neoclássica, a nova economia da migração, a teoria do mercado de trabalho dual e a teoria dos sistemas mundiais. Na segunda categoria, encontram-se a teoria de redes migratórias, a teoria institucional, a teoria da causação acumulativa e a teoria transnacional.

Uma das primeiras teorias contemporâneas que abordam os fatores que desencadeiam as migrações foi baseada na teoria econômica neoclássica. De acordo com essa teoria, em sua perspectiva macroeconômica, a migração internacional seria causada por diferenças geográficas de oferta e demanda por mão-de-obra. Assim, os países com maior disponibilidade de força de trabalho em relação ao capital tenderiam a oferecer salários mais baixos enquanto os países onde a disponibilidade de capital fosse mais abundante em relação à mão-de-obra tenderiam a oferecer um salário de mercado superior. Como resultado desse movimento, a oferta de mão-de-obra diminui e os salários aumentam nos países que dispõem de menos capitais, enquanto nos países ricos a oferta de mão-de-obra aumenta causando redução nos salários até encontrar um ponto de equilíbrio, no qual o diferencial de salários refletiria apenas os custos pecuniários e psicológicos do movimento de pessoas entre os países (MASSEY et al., 1993, p. 433).

Do ponto de vista microeconômico, a migração resultaria de uma escolha individual, na qual atores racionais decidem migrar a partir de um cálculo de custos e benefícios que resulta positivo em termos monetários. Assim, as pessoas escolheriam migrar para onde pensam que podem ser mais produtivas, levando em consideração todas as dificuldades colocadas pela mudança de país. Segundo Douglas Massey (1999),

[p]eople choose to move to where they can be most productive, given their skills; but before they can capture the higher wages associated with greater labor productivity they must undertake certain investments, which include the material costs of traveling, the costs of maintenance while moving and looking for work, the effort involved in learning a new language and culture, the difficulty experienced in adapting to a new labor market, and the psychological costs of cutting old ties and forging new ones (MASSEY, 1999, p. 36).

Apesar de sua importante contribuição para os estudos migratórios, a teoria neoclássica não dispõe de recursos suficientes para classificar e ordenar os fatores determinantes da migração no espaço. O modelo não explica por que um determinado grupo de indivíduos migra para um determinado país em detrimento de outro 
(CASTLES e MILLER, 2009). Isto porque está baseada em expectativas racionais, a partir do pressuposto de que o indivíduo detém conhecimento preciso sobre as condições de vida no país de destino quando, na verdade, o migrante possui informações limitadas, que muitas vezes podem não corresponder à realidade. Some-se a isso o fato de que os migrantes "estão sujeitos a uma série de restrições, principalmente a falta de poder face aos empregadores e governos" (CASTLES e MILLER, 2009, p. 23).

Massey et al. (2006, p. 34) também questionam o argumento de que a migração levaria a uma elevação do nível salarial nas sociedades de origem e a uma redução nas sociedade de destino, de forma que os movimentos migratórios deveriam continuar até os salários serem equiparados em ambas as sociedades. Os autores argumentam, porém, que, ainda que as diferenças salariais desaparecessem, a migração não cessaria com a igualdade de salários, mas com a realização de melhorias nas condições de vida nos países de origem.

Outra teoria, a nova economia da migração, incorpora as entidades sociais para explicar as causas da migração laboral. Nessa perspectiva, a decisão de migrar deixa de ser explicada como uma decisão individual para se tornar uma decisão coletiva. Além das famílias ou dos domicílios, a comunidade "age coletivamente, não apenas para maximizar os rendimentos esperados, mas também para minimizar os riscos e os constrangimentos associados a diversas falhas de mercado" (MASSEY, 1999, p. 36). Nos países desenvolvidos, os riscos para a renda das famílias são minimizados por meio do mercado de crédito, de seguros privados e pelas políticas governamentais. Assim, as famílias podem obter recursos em caso de quebra de safra ou queda acentuada de preços de produtos no campo e seguro-desemprego para o trabalhador da cidade.

Já nos países em desenvolvimento, o acesso a crédito é mais restrito e o governo muitas vezes não tem recursos para garantir o sustento das famílias. Nesses casos, cabe às famílias diversificar o risco por meio da migração de alguns de seus membros, na expectativa de receber remessas do exterior (MASSEY et al., 1993, p. 436-437). Além disso, a melhoria de renda de uma unidade familiar relativamente aos demais membros de uma mesma comunidade acrescenta outro fator de incentivo a que mais famílias destinem um de seus integrantes à migração, porque a percepção de privação dos demais em relação à primeira aumenta.

To illustrate, consider an increase in the income of affluent households. If poor households' incomes are unchanged, then their relative deprivation 
increases. If household utility is negatively affected by relative deprivation, then even though a poor household's absolute income and expected gains from migration remain unchanged, its incentive to participate in international migration increases if, by sending a family member abroad, it can hope to reap a relative income gain in the community. The likelihood of migration thus grows because of the change in other households' incomes (MASSEY, 1999, p. 37). (grifo original)

Para a teoria do mercado de trabalho dual ou segmentado, as decisões tomadas por indivíduos ou famílias não são os principais fatores a explicar as migrações internacionais, mas sim a demanda permanente por mão-de-obra que é inerente à estrutura econômica das nações desenvolvidas (MASSEY et al., 1993, p. 440). Essa teoria argumenta que a migração internacional é causada, principalmente, por fatores de atração (pull) nos países receptores, em função de uma crônica e inevitável necessidade de mão-de-obra imigrante. De acordo com a teoria do mercado dual, os mercados de trabalho, nos países desenvolvidos, podem ser classificados como de natureza primária, de produção intensiva em capital e mão-de-obra predominantemente de alta qualificação, e secundária, caracterizados por métodos de produção intensivos em trabalho e por mão-de-obra predominantemente de baixa qualificação (MASSEY et al., 1993, p. 440). Nessa perspectiva, os trabalhadores nativos têm preferência pelo setor primário, pois os empregos são mais seguros, a remuneração é maior e existe a possibilidade de ascensão na hierarquia social. Do lado dos empregadores, dispensar esses contingentes é mais difícil, pois muitas vezes são sindicalizados e de difícil substituição devido à alta especialização. Já os empregos do setor secundário oferecem salários mais baixos e condições de trabalho mais instáveis, com reduzida mobilidade social. Nesse segmento, a demanda é especialmente por trabalhadores com pouca ou nenhuma qualificação, que são facilmente substituídos em caso de necessidade (MASSEY et al., 1993; CASTLES e MILLER, 2009).

A teoria de sistemas mundiais ou do sistema-mundo (MASSEY et al., 1993, p. 444) entende a migração internacional a partir de uma perspectiva global. Essa perspectiva aponta a penetração de relações econômicas capitalistas em áreas periféricas ou sociedades não capitalistas. O estabelecimento dessas relações altera a dinâmica social no que se refere às estruturas tradicionais de posse e uso da terra, das matériasprimas e do trabalho. Essas mudanças causam um aumento no contingente de pessoas social e economicamente desvinculadas com a região que habitam e, portanto, dispostas a migrar para as cidades globais, centros de decisão do capitalismo, cuja estrutura cria forte demanda por trabalho imigrante. Massey et al. (1993) apontam, ainda, que a 
incorporação dos trabalhadores imigrantes não ocorre apenas no setor secundário, como afirma a teoria do mercado de trabalho segmentado, mas também no setor primário. As atividades concentradas nas grandes cidades globais necessitam tanto de trabalhadores migrantes com baixas qualificações como de trabalhadores migrantes altamente qualificados para indústrias de alta tecnologia.

$\mathrm{Na}$ perspectiva da teoria dos sistemas mundiais, fatores materiais e ideológicos também contribuem para o estímulo à migração. Quanto aos primeiros, pode-se destacar o fato de que os investimentos dos países desenvolvidos em países em desenvolvimento acompanham melhorias em infraestrutura e comunicações para facilitar o movimento de bens, informação e capital, os quais tendem a favorecer também o trânsito de migrantes.

Com relação aos fatores ideológicos, trata-se das conexões culturais que são estabelecidas entre os países capitalistas e os países do mundo em desenvolvimento nos quais atuam. Segundo Massey et al. (1993, p. 446), os vínculos culturais são duradouros e refletem um passado em que países centrais estabeleceram sistemas administrativos e educacionais nas colônias à semelhança dos seus próprios, a fim de governar e explorar essas regiões periféricas. Além disso, essas conexões são reforçadas pela comunicação de massa a partir dos países centrais, que veiculam mensagens sobre o estilo de vida e os padrões de consumo desses países. Juntamente com a infraestrutura de transportes e comunicações, essas mensagens estimulam fluxos migratórios das áreas periféricas para determinados países do centro.

As teorias apresentadas acima lidam com os fatores que desencadeiam os movimentos migratórios. Trataremos agora das correntes teóricas que se ocupam da continuidade dos movimentos migratórios no decorrer do tempo, quais sejam, a teoria das redes migratórias, a teoria institucional, a teoria da causação acumulativa, a teoria dos sistemas de migrações e a teoria transnacional ou da comunidade transnacional.

Para a teoria de redes migratórias, como resultado de grandes fluxos de migrantes internacionais, são formados vínculos interpessoais entre os que já migraram e os potenciais migrantes. Essas conexões tendem a formar redes que podem ajudar esses novos migrantes de mesma origem daqueles já estabelecidos a obter informações sobre as possibilidades de acesso a melhores condições de vida e renda no país de destino, financiar a viagem, encontrar um emprego e hospedagem adequada (MASSEY et al., 1993, p.488). Essas redes têm, portanto, o potencial de reduzir os custos e os riscos da migração e facilitar a integração dos migrantes na sociedade de destino, o que 
acaba fortalecendo a própria rede e contribuindo para sua expansão através das fronteiras.

As críticas à teoria de redes recaem sobre as dificuldades para explicar grandes fluxos migratórios internacionais e como esses fluxos migratórios se expandem e persistem ao longo do tempo. Para Krissman (2005), as análises não podem supor que as redes migratórias se resumem exclusivamente entre aos membros das mesmas cidades de origem e devem incluir outros atores envolvidos com a origem e a perpetuação dos fluxos migratórios, tais como: empregadores, agenciadores e outros intermediários.

De acordo com a teoria institucional, à medida que a migração internacional passa a ocorrer, instituições privadas e organizações voluntárias surgem para atender a demanda criada pelo desequilíbrio entre o grande número de pessoas que desejam entrar nos países ricos e o número limitado de vistos que estes estão dispostos a oferecer (MASSEY et al., 1993, p. 450). Primeiramente, esse desequilíbrio abre oportunidade para o estabelecimento de negócios lucrativos envolvendo o deslocamento internacional de pessoas. Entidades privadas se ocupam da exploração de migrantes mediante pagamento por transporte clandestino através das fronteiras, falsificação de documentos, casamentos arranjados com nativos e residentes legais, bem como acesso a crédito, alojamento e outros serviços no país de destino, criando um mercado negro para a imigração.

Em paralelo, surgem grupos humanitários que prestam apoio aos migrantes, oferecendo abrigo, aconselhamento, apoio legal, e até mesmo mantendo-os fora do alcance das autoridades (MASSEY et al., 1993, p. 450). Com o tempo, o processo de institucionalização se consolida, tornando mais difícil para os governos exercer controle sobre os fluxos migratórios, pois, quanto mais restritivas forem as políticas migratórias, mais lucrativo se torna o mercado negro e maior a resistência das entidades de assistência.

A teoria da causação acumulativa Para sugere que a migração altera $o$ contexto social no qual serão tomadas as decisões acerca da própria migração, de forma que tornam esta mais provável de ocorrer (MASSEY et al., 1993, p. 451). Tomando-se como exemplo a distribuição de renda, uma vez que algumas famílias em uma comunidade passam a se beneficiar da renda extra constituída por remessas do exterior de algum membro que emigrou, elas tendem a subir alguns degraus na escala social. Os 
demais membros estarão mais propensos a enviar algum integrante da família para o exterior a fim de reduzir essa distância, e assim, sucessivamente.

Outros fatores destacados por Massey et al. (1993) que podem indicar um processo circular de causação cumulativa que perpetuam as migrações estão relacionados à compra de propriedades e uso de métodos capital-intensivos na produção agrícola com os recursos enviados por emigrantes da comunidade. $\mathrm{O}$ autor aponta que esse processo deslocaria trabalhadores de atividades tradicionais para os fluxos migratórios. Destaca também o desenvolvimento de uma cultura de migração, que altera as percepções dos migrantes e da comunidade, e tende a aumentar a probabilidade de futuras migrações. Uma vez que o migrante tenha tido contato com uma economia de país capitalista avançado, seus gostos e motivações mudam e ele percebe que não terá acesso a esses produtos e estilo de vida no seu local de origem, o que pode impulsionar uma nova migração (p. 452). Quanto à comunidade, a migração se torna profundamente introjetada no comportamento social e passa a ser percebida como um valor.

Ao longo do tempo, a migração tende a se tornar menos seletiva, à medida que custos e riscos diminuem em decorrência da formação das redes migratórias. Assim, os indivíduos com menos qualificação se tornam potenciais migrantes, em um processo que se retroalimenta. Nos países receptores, as ocupações que contam com maiores contingentes de migrantes se tornam estigmatizadas e os nativos passam a recusá-las, aumentando a demanda por migrantes. Segundo Massey et al. (1993, p. 453), esse estigma decorre da presença de migrantes e não da característica do trabalho. Os mecanismos de causação acumulativa muitas vezes se encontram fora do alcance dos governos.

A teoria dos sistemas de migrações se baseia nos aportes das teorias de sistemas mundiais, redes migratórias, institucional e causação cumulativa para sugerir que os fluxos migratórios adquirem uma medida de estabilidade e estrutura no tempo e no espaço, permitindo a identificação de sistemas estáveis de migração internacional, que se caracterizam por um intercâmbio relativamente intenso de capitais, bens, produtos e pessoas entre alguns países e menos intenso entre outros. Um sistema internacional de migração geralmente inclui uma região central receptora, que pode ser um país ou um conjunto de países, e um conjunto de países emissores ligados por grandes fluxos de imigração.

A teoria transnacional, por sua vez, se refere aos múltiplos vínculos e interações que conectam as pessoas ou instituições através das fronteiras dos Estados- 
nação (VERTOVEC, 1999, p. 447). A perspectiva transnacionalista busca compreender as novas migrações enquanto transmigrações, pois, embora o migrante invista social, econômica e politicamente em sua nova sociedade, continua a participar na vida diária da sociedade a partir da qual emigrou, mas que não abandonou (GLICK SCHILLER, 1999, p. 94).

A globalização proporciona significativos avanços nas tecnologias de transportes e comunicações, facilitando aos migrantes a manutenção dos contatos com seus locais de origem. Com isso, observa-se um aumento no crescimento da mobilidade circular ou temporária, com os migrantes se deslocando continuamente entre locais nos quais mantêm vínculos sociais, econômicos ou culturais (CASTLES e MILLER, 2009, p. 30).

De acordo com Glick Schiller (1999), transmigração não deve ser confundida com diáspora. Para a autora, transmigrantes são pessoas que têm atuação social em dois ou mais Estados-nação, um dos quais é reconhecido como seu Estado de origem. Esses transmigrantes participam de comunidades transnacionais, grupos baseados em dois ou mais países, envolvidos em atividades significativas, recorrentes e duradouras, que podem ser de natureza econômica, política, social ou cultural.

As diásporas, por outro lado, são mais comumente compreendidas como populações dispersas que se atribuem uma identidade, a partir de crenças e práticas culturais, língua ou religião, com base em um mito comum de ancestralidade, mas cujo sentimento de herança compartilhada não está relacionado a um Estado contemporâneo (1999, p. 96). Além disso, o termo "diáspora" está mais relacionado a deslocamentos forçados, como no caso dos judeus e dos escravos africanos. Assim, enquanto "diáspora" tem fortes conotações sentimentais, a expressão “comunidades transnacionais" assume um caráter mais neutro (CASTLES e MILLER, 2009, p. 31).

O panorama apresentado acerca das teorias explicativas para as migrações internacionais permite concluir que as teorias disponíveis até o momento para explicar a origem e a continuidade dos fluxos migratórios possuem um caráter de complementaridade. As migrações constituem um fenômeno bastante complexo, e as diferentes perspectivas fornecem um arcabouço teórico importante para sua compreensão e para a formulação de políticas adequadas para lidar com a questão.

As teorias explicativas apresentadas podem colaborar inclusive para 0 entendimento, por parte dos formuladores da política externa, de que as migrações são um fenômeno internacional de grande repercussão, que apresenta desafios, mas também 
oferece oportunidades para a inserção internacional do Brasil, conforme se verá mais adiante neste trabalho.

Em seguimento a essa discussão, será apresentado um panorama histórico e estatístico das principais migrações no Brasil.

\subsection{Breve histórico das migrações no Brasil}

Segundo Silva (2005), o Brasil caracteriza-se historicamente como um país aberto à imigração estrangeira. No período entre 1808 e 1955, o Brasil posicionou-se em quarto lugar entre os países do continente, em número de imigrantes recebidos $(4,3$ milhões) atrás apenas dos Estados Unidos (40 milhões), Argentina (7 milhões) e Canadá (5,2 milhões).

A história da imigração para o Brasil costuma ser periodizada em três fases: de 1808 a 1850, de 1850 a 1930, de 1930 aos nossos dias. Na primeira, que vai da chegada da Corte Portuguesa ao Rio de Janeiro, com a Abertura dos Portos, até a entrada em vigor da Lei Eusébio de Queirós, que proibiu o tráfico de escravos, a fácil obtenção de mão-de obra escrava, a instabilidade política do período regencial e Guerra dos Farrapos (1835-1845) resultaram em pequeno fluxo imigratório, cujas principais correntes eram de açorianos, suíços, alemães e prussianos (SILVA, 2005, p. 115). Sobre esta fase, importa destacar que não se pode considerar "imigração", para os fins desta pesquisa, o transporte de aproximadamente 5 milhões de escravos africanos, que vieram para o Brasil após serem capturados e presos nas localidades que atualmente conhecemos como Nigéria, Guiné, Angola, Congo e Moçambique (LOPES, 2009, p. 276).

A fase seguinte abrange o período compreendido entre a Lei Eusébio de Queirós e a Revolução de 1930. Esse período é marcado pela proibição do tráfico negreiro, pela intranquilidade social no sul da Itália, decorrente do processo de unificação do Estado italiano e pela necessidade de mão de obra nas fazendas de café. Houve maior entrada de imigrantes italianos, alemães, espanhóis, sírio-libaneses, poloneses, ucranianos e japoneses (SILVA, 2005, p. 115).

A introdução de imigrantes é motivada pela necessidade de substituir o trabalho escravo pelo assalariado no cultivo do café. Não obstante, Lopes (2009, p. 277) identifica outras motivações relevantes, tais como, a pressão exercida por outras nações 
em torno do encerramento do tráfico negreiro e da abolição do sistema escravocrata no Brasil; a predisposição das elites em promover o "branqueamento" da população brasileira; e o apoio conferido pelos cafeicultores à introdução do imigrante como um meio para resguardar o sistema produtivo que lhes conferia poder político e econômico. O aspecto ideológico relativo ao "branqueamento" da população explica o fato de que a imigração japonesa somente foi permitida após as restrições ao influxo de imigrantes europeus.

A terceira fase inclui o período que vai da Revolução de 1930 até nossos dias, destacando-se pela diminuição acentuada do fluxo migratório, exceto décadas de 1950 e 1970. Em 1950, a reconstrução da Europa após o fim da Segunda Guerra Mundial provocou um aumento da emigração. Mais tarde, o "milagre brasileiro" atraiu investimentos e imigrantes, com aumento dos fluxos, principalmente dos países da América do Sul (SILVA, 2005, p. 117).

Variáveis políticas também contribuíram para atrair refugiados/vítimas de perseguição política. De acordo com Martes (2010, p. 12), a imigração recente para o Brasil obedece a quatro diferentes padrões:

1) Perseguição política (1970-1980): profissionais liberais. Predomínio de argentinos, chilenos e uruguaios, que representam as comunidades de maior nível de escolaridade (Censo, 2000);

2) Refugiados: africanos (Angola e Libéria), colombianos e asiáticos (Afeganistão);

3) Migração de profissionais (até hoje): empregados qualificados de multinacionais e transnacionais e profissionais liberais. Fluxos documentados no Ministério de Trabalho e Polícia Federal. Predomínio de europeus e latino- americanos (sobretudo argentinos);

4) Migração laboral (1970 até hoje): trabalhadores de baixa qualificação e nível de escolaridade. Fluxo voluntário, nãodocumentado. Predomínio de sul-americanos (chilenos, bolivianos, paraguaios e peruanos) e também africanos (sobretudo Angola e Moçambique).

Cabe destacar que, durante os anos de ditadura militar na América Latina, profissionais liberais de classe média argentinos, uruguaios e chilenos refugiados da perseguição política em seus países imigraram para o Brasil. Aqui encontravam trabalho qualificado, inserção social e reconhecimento na academia. A escolha pelo Brasil se deu pelas redes sociais e profissionais nas quais se inseriam, pela facilidade da língua e pela proximidade geográfica (MARTES, 2010, p. 12).

Na década de 1980, com a crise da dívida externa, desemprego, inflação e estagnação econômica, começa a ocorrer um movimento de emigração de brasileiros. 
Não obstante, nesse período intensifica-se a imigração irregular de bolivianos e coreanos, principalmente, e o acesso mais importante é a fronteira com o Paraguai. O número de imigrantes ilegais era significativo, mas, na década de 1980, o governo promoveu anistia aos estrangeiros que aqui viviam na clandestinidade (SILVA, 2005, p. 118). Em 1988, foram beneficiados 39.131 estrangeiros, dos quais 14.006 bolivianos (36\%), 9.940 chineses (25\%), 3.091 libaneses (8\%) e 2.577 sul-coreanos (7\%). Os restantes 9.517 (24\%) eram de outras 77 nacionalidades (BARRETO, 2001, p. 65).

Segundo estatísticas oficiais, a população de estrangeiros residentes no Brasil, em 1991, era de 607 mil, representando $0,41 \%$ da população total; em 2000, de 431 mil, perfazendo $0,25 \%$ do total; e em 2010, os estrangeiros somavam 510 mil ou $0,27 \%$ da população.

Tabela 3. Relação entre o quantitativo de estrangeiros residentes e a população total - em milhares

\begin{tabular}{|c|c|c|c|}
\hline Ano & Total & Estrangeiros & \% Estrangeiros \\
\hline $\mathbf{1 9 9 1}$ & 146.816 & 607 & $0,41 \%$ \\
\hline $\mathbf{2 0 0 0}$ & 169.873 & 431 & $0,25 \%$ \\
\hline $\mathbf{2 0 1 0}$ & 190.756 & 510 & $0,27 \%$ \\
\hline $\mathbf{2 0 1 1}$ & 197.825 & 667 & $0,34 \%$ \\
\hline $\mathbf{2 0 1 2}$ & 199.689 & 720 & $0,36 \%$ \\
\hline $\mathbf{2 0 1 3}$ & 201.467 & 762 & $0,38 \%$ \\
\hline
\end{tabular}

Fonte: IBGE-Séries Estatísticas. Dados de 1991 a 2010 referem-se ao Censo Demográfico, e os de 2011 a 2013, à Pesquisa Nacional por Amostra de Domicílios (PNAD).

A tabela 3 informa que, em termos relativos, os estrangeiros têm representado uma parcela muito pequena da população brasileira, e que a queda no contingente, que foi de $-29 \%$, representou uma variação negativa ainda maior na participação entre 1991 e 2000 , de $-39 \%$. Houve, entretanto, leve aumento entre 2000 e 2010 , com variação positiva de $18 \%$ em termos absolutos (de 431 para 510) e de $8 \%$ em relação à participação no total da população.

Em relação à nacionalidade de origem, observando-se os dados dos últimos censos de 2000 e 2010, verifica-se que os quantitativos de estrangeiros residentes ainda se apresentam bastante relacionados aos fluxos migratórios tradicionais oriundos da Europa (Portugal, Espanha e Itália) e do Japão. Também se verifica o aumento da imigração a partir dos países vizinhos (Paraguai, Bolívia, Argentina e Uruguai), bem como um aumento expressivo da imigração chinesa. 
Tabela 4. Imigrantes - principais países de nacionalidade - milhares

\begin{tabular}{|l|c|c|c|c|}
\hline & $\mathbf{2 0 0 0}$ & $\mathbf{2 0 1 0}$ & Variação & Var. \% \\
\hline Portugal & 213 & 138 & -75 & $-35 \%$ \\
\hline Japão & 71 & 49 & -22 & $-31 \%$ \\
\hline Paraguai & 29 & 39 & 10 & $34 \%$ \\
\hline Bolívia & 20 & 39 & 19 & $95 \%$ \\
\hline Itália & 55 & 37 & -18 & $-33 \%$ \\
\hline Espanha & 44 & 31 & -13 & $-30 \%$ \\
\hline Argentina & 28 & 29 & 1 & $4 \%$ \\
\hline Uruguai & 25 & 24 & -1 & $-4 \%$ \\
\hline Estados Unidos & 14 & 24 & 10 & $71 \%$ \\
\hline China & 10 & 19 & 9 & $90 \%$ \\
\hline Alemanha & 20 & 16 & -4 & $-20 \%$ \\
\hline Chile & 17 & 15 & -2 & $-12 \%$ \\
\hline Peru & 10 & 15 & 5 & $50 \%$ \\
\hline Líbano & 16 & 12 & -4 & $-25 \%$ \\
\hline França & 8 & 10 & 2 & $25 \%$ \\
\hline & $\mathbf{5 8 0}$ & $\mathbf{4 9 7}$ & $\mathbf{- 8 3}$ & $\mathbf{- 1 4 \%}$ \\
\hline Outros Subtotal & 104 & 96 & -8 & $-8 \%$ \\
\hline & $\mathbf{6 8 4}$ & $\mathbf{5 9 3}$ & $\mathbf{- 9 1}$ & $\mathbf{- 1 3 \%}$ \\
\hline
\end{tabular}

Fonte: Cavalcanti et al. (2014) com base em dados do IBGE.

Obs.: Os dados obtidos foram elaborados pelos autores com base em dados dos Censos de 2000 e 2010. Os dados do Censo de 1991 não foram encontrados no site do IBGE, assim como não foi possível encontrar dados referentes a 1995. Outras fontes consultadas apresentaram dados muito inconsistentes para uma comparação razoável dos quantitativos.

Conforme apontado por Cavalcanti et al. (2014, p. 26), o Censo de 2010 não conseguiu captar o fenômeno da chegada dos haitianos. O fluxo migratório se intensificou após a realização do levantamento e estima-se que o número de haitianos documentados já seja de aproximadamente 30 mil (BRASIL, 2014a).

Os dados constantes da tabela 4 foram obtidos no documento "A Inserção dos Imigrantes no Mercado de Trabalho Brasileiro, elaborado pelo Observatório das Migrações Internacionais (ObMigra) em $2014^{14}$. Trata-se de estudo que procurou observar o perfil da migração laboral no Brasil entre os anos de 2011 a 2013, período que se encontra além do recorte temporal desta pesquisa, razão pela qual não estenderemos a análise sobre a variação dos fluxos.

Com relação aos dados encontrados, cabe ressaltar que os números do IBGE e os apresentados pelo documento, baseados também nos Censos, apresentam algumas divergências: para 2000, o número de imigrantes é de 431 mil segundo o IBGE contra

\footnotetext{
${ }^{14}$ Resultado de parceria entre o Conselho Nacional de Imigração (CNIg) e a Universidade de Brasília (UnB), o Observatório tem como meta "ampliar o conhecimento sobre os fluxos migratórios internacionais no Brasil, mediante estudos teóricos e empíricos, e apontar estratégias para a inovação social de políticas públicas dirigidas às migrações internacionais”. Fonte: http://portal.mte.gov.br/obmigra/sobre.htm. Acesso em 15/01/2015.
} 
684 mil conforme a análise do ObMigra, e, para 2010, os valores se aproximam, com o IBGE registrando 510 mil contra 497 mil do estudo.

A dificuldade de conciliação de dados de séries históricas constantes das diversas bases oficiais ainda é um dos obstáculos com que se defrontam os pesquisadores que se dispõem a extrair sentido dessas estatísticas. Por falta de uma metodologia comum consolidada no que se refere aos dados sobre imigração e emigração, as estatísticas podem passar mensagens inconsistentes para a interpretação dos dados, inclusive para órgãos oficiais de imprensa que poderiam também servir como fonte. A título ilustrativo, apresenta-se matéria da Empresa Brasil de Comunicação, de 2012, a qual informa:

\begin{abstract}
Movimentos de imigração para o Brasil se intensificaram em 2012, especialmente de haitianos, bolivianos, espanhóis, franceses e americanos. Segundo dados do Ministério da Justiça, em seis meses, a imigração cresceu $50 \%$, em comparação com o total de entradas verificado no final do ano de 2010. Atualmente, o país conta com 1,5 milhão de imigrantes legalizados (EBC, 2012). (grifo nosso)
\end{abstract}

Entretanto, esses "imigrantes legalizados" não necessariamente representam estrangeiros residentes que poderiam constar do Censo do IBGE. Na verdade, pode se tratar de qualquer estrangeiro que esteja com documentação regular no Brasil, ou seja, de posse de algum tipo de visto entre os sete tipos previstos na Lei no $6.815 / 80$, a saber: i) de trânsito; ii) de turista; iii) temporário (que abrange os subtipos de viagem cultural ou missão de estudos; viagem de negócios; de artista e desportista; estudante; cientista professor, técnico ou profissional de outra categoria, sob regime de contrato ou a serviço do governo brasileiro; correspondente de jornal, revista, rádio, televisão ou agência estrangeira; e ministro de confissão religiosa ou membro de instituição de vida consagrada, congregação ou ordem religiosa); iv) permanente; v) de cortesia; vi) oficial; e vii) diplomático.

Cabe registrar, ainda, que as estatísticas não alcançam os indocumentados, impossibilitando uma estimativa acerca do número total exato de imigrantes residindo no Brasil. É sabido que, em geral, os dados censitários sobre imigração internacional são subestimados, devido ao fato de que a grande maioria dos imigrantes residem no país de destino de modo clandestino. Isso se aplica no caso dos fluxos migratórios em direção ao Brasil, cujas informações censitárias encontram-se bem abaixo de estimativas e levantamentos extraoficiais (ANTICO, 1998).

Com relação ao número de brasileiros vivendo no exterior, a situação de 
imprecisão de dados é similar à que se verifica em relação aos estrangeiros. A esse respeito, o Ministério das Relações Exteriores divulga, desde 2007, um relatório contendo estimativas baseadas em informações enviadas anualmente pelos Consulados e Embaixadas sobre o número de brasileiros residentes em suas respectivas jurisdições.

Tabela 5. Estimativas de brasileiros residentes no exterior - em milhares

\begin{tabular}{|l|c|c|c|c|c|c|c|c|c|}
\hline \multicolumn{1}{|c|}{ Países-Regiões } & $\mathbf{1 9 9 6}$ & $\mathbf{2 0 0 0}$ & $\mathbf{2 0 0 1}$ & $\mathbf{2 0 0 3}$ & $\mathbf{2 0 0 8}$ & $\mathbf{2 0 0 9}$ & $\mathbf{2 0 1 1}$ & $\mathbf{2 0 1 2}$ & $\mathbf{2 0 1 3}$ \\
\hline Estados Unidos & 580 & 799 & 894 & 713 & 1.240 & 1.280 & 1.388 & 1.066 & 1.007 \\
\hline Paraguai & 350 & 455 & 370 & 310 & 488 & 300 & 200 & 202 & 460 \\
\hline Japão & 263 & 225 & 263 & 269 & 310 & 280 & 231 & 210 & 186 \\
\hline Europa & 136 & 197 & 332 & 291 & 767 & 816 & 912 & 752 & 737 \\
\hline Outros - América do Sul & 49 & 38 & 92 & 112 & 124 & 214 & 207 & 167 & 162 \\
\hline Outros & 41 & 174 & 91 & 110 & 116 & 151 & 185 & 125 & 249 \\
\hline \multicolumn{1}{|c|}{ Total } & $\mathbf{1 . 4 1 9}$ & $\mathbf{1 . 8 8 8}$ & $\mathbf{2 . 0 4 2}$ & $\mathbf{1 . 8 0 5}$ & $\mathbf{3 . 0 4 5}$ & $\mathbf{3 . 0 4 1}$ & $\mathbf{3 . 1 2 3}$ & $\mathbf{2 . 5 2 2}$ & $\mathbf{2 . 8 0 1}$ \\
\hline
\end{tabular}

Fontes: Dados de 1996 a 2003 elaborados por Patarra (2005, p. 26), a partir de informações fornecidas pelo MRE. Estimativas de 2008 a 2013 obtidas nos Relatórios de Estimativas Populacionais das Comunidades Brasileiras no Exterior, disponíveis no site do MRE na Internet. Não foram encontrados dados referentes a 1995.

* Dados do Relatório "Diplomacia Consular" (BRASIL, 2012).

Obs. O MRE não disponibilizou dados de 2010.

Ocorre, porém, que grande parte desses brasileiros encontra-se em situação migratória irregular e evita submeter-se a sondagens e censos, ou mesmo a matricular-se nas repartições consulares. Segundo o Itamaraty,

As estimativas do número de brasileiros no exterior feitas pelo Itamaraty buscam levar em conta vários fatores, como: dados oficiais fornecidos por autoridades migratórias locais; censos oficiais; número de eleitores registrados na jurisdição; número de matriculados nos consulados; sondagens junto à comunidade; solicitações de passaportes e outros documentos por brasileiros; movimento geral da repartição e de consulados itinerantes; dados disponíveis sobre saída do país e retorno de brasileiros; percentuais de redução de remessas; publicações da Organização Internacional para as Migrações (OIM); estudos da OCDE; trabalhos acadêmicos e artigos na imprensa (BRASIL, 2012, p. 21).

A edição do Censo 2010 do IBGE apresentou, pela primeira vez, estimativas relativas ao número de brasileiros vivendo no exterior, contabilizando 491.645 pessoas. Foi perguntado aos entrevistados se alguma pessoa que residira anteriormente com algum morador do domicílio estaria vivendo no exterior (IBGE, 2010, p. 56).

O Instituto reconhece, porém algumas limitações do levantamento, que levaram a amostra a ser "subnumerada" em relação às estimativas do MRE. Essas limitações estão relacionadas à "possibilidade de todas as pessoas que residiam em determinado domicílio terem emigrado ou que aquelas que ficaram em território brasileiro tenham vindo a falecer". O Relatório destaca, ainda, que omissões podem ter ocorrido devido ao 
fato de que "pessoas que fizeram o movimento rumo ao exterior há muito tempo podem ser desconsideradas" (IBGE, 2010, p. 56).

O Censo 2010 apontou que 94,3\% do contingente de emigrantes concentram-se faixa etária de 15 a 59 anos de idade, sendo que os emigrantes com idades de 20 a 34 anos contribuíram com $60,0 \%$ do total de emigrantes. As mulheres são maioria em todos os grupos de idade. Segundo o IBGE, esses dados sinalizam que os deslocamentos foram "eminentemente determinados pela necessidade da venda da força de trabalho no estrangeiro e que foram realizados de forma individual, ou seja, em maior medida sem acompanhamento da família”, uma vez que a participação dos grupos de pessoas com até 14 anos de idade e de idosos, é de apenas 4,4\% e 1,4\%, respectivamente.

Os emigrantes são oriundos principalmente das regiões Sudeste (49\%) e Sul (17\%), seguidos das regiões Nordeste (15\%), Centro-Oeste (12\%) e Norte (7\%).

Em relação aos países de destino, 70\% dos emigrantes brasileiros se dirigem majoritariamente aos Estados Unidos (23,8\%), Portugal (13,4\%), Espanha $(9,4 \%)$, Japão $(7,4 \%)$, Itália $(7,0 \%)$ e Inglaterra (6,2\%). O Relatório analisa que "laços históricos e redes sociais poderiam explicar essas preferências por deslocamentos mais longos em detrimento da movimentação no âmbito dos países vizinhos." Interessante notar, contudo, a discrepância existente entre as estimativas do IBGE e do MRE no que se refere ao Paraguai: para o primeiro, este país acolheria apenas $1 \%$ da população brasileira emigrante, enquanto, para o segundo, responderia por 14\% (em 2011). Como os dados do MRE se baseiam em boa parte no movimento registrado pelos consulados e embaixadas, essa diferença poderia ser explicada pela transmigração de brasileiros, que desempenham atividades significativas e continuadas dos dois lados da fronteira.

De toda forma, os dados absolutos são bastante incongruentes para possibilitar uma conclusão acerca das variações dos fluxos no tempo. Além disso, uma análise mais aprofundada desses movimentos de entrada e saída de nacionais foge ao escopo desta pesquisa, na medida em que demandaria reorientação do foco do trabalho para a questão específica da emigração brasileira e ao estudo das metodologias de apuração dessas estatísticas. Apesar disso, vale citar a justificativa apresentada pelo IBGE a respeito dos dados referentes às migrações:

A falta de registros administrativos confiáveis e a situação "clandestina" de parte dos migrantes internacionais, tanto entre os que saem como entre os que chegam ao Brasil, exige um esforço metodológico para que estimativas do número de migrantes e saldos migratórios internacionais sejam precisos e forneçam informações confiáveis. Nesse sentido, os Censos Demográficos 
são considerados a fonte de dados mais completa sobre migração do Pais, dado que fornecem dados diretos sobre os estoques de migrantes e também possibilitam, utilizando-se técnicas indiretas, estimar o saldo migratório internacional (CAMPOS, 2011, p. 78).

\subsection{Evolução da legislação migratória: manutenção de anacronismos}

A Lei no 6.815, de 1980, mais conhecida como Estatuto do Estrangeiro, "define a situação jurídica do estrangeiro no Brasil e cria o Conselho Nacional de Imigração". Nos primeiros artigos da referida Lei estão destacados os princípios que a orientam, quais sejam, a segurança nacional e a defesa do trabalhador nacional.

Art. 2o $\mathrm{Na}$ aplicação desta Lei atender-se-á precipuamente à segurança nacional, à organização institucional, aos interesses políticos, sócioeconômicos e culturais do Brasil, bem assim à defesa do trabalhador nacional.

A legislação vigente sobre migrações revela a permanente tensão entre a soberania e os direitos humanos. O reconhecimento da migração como um direito humano esbarra nos constrangimentos impostos pela autoridade estatal, em forte contradição com a ideia de universalidade dos direitos humanos. Na visão de BRITO (2011, p.7),

\footnotetext{
Hannah Arendt considera que a dissociação entre direitos humanos e soberania nacional serviu de ante-sala para ruptura total dos direitos humanos nos regimes totalitários. (...) A questão fundamental, na perspectiva arendtiana seria recuperar a tópica kantiana da "hospitalidade universal", deslocando-se do espaço da tríade Estado-Povo-Território para a compreensão da humanidade como fonte de direito. Os direitos humanos seriam fundamentados não na natureza humana, mas na própria humanidade à qual todos pertencem, sem restrições de nacionalidade. Pertencer à humanidade significa ter direito a ter direitos e ser humano seria a sua a garantia efetiva.
}

Para Ramos et al. (2014), a legislação brasileira é inadequada para lidar com os desafios impostos ao Brasil pelo fenômeno migratório. A Lei no 6.815 , de 1980, é inspirada na Doutrina de Segurança Nacional do período do Regime Militar (19641985). A principal preocupação era facilitar a expulsão de estrangeiros considerados "subversivos". Com a redemocratização do País, esse pensamento se tornou obsoleto, e essa lei se tornou incompatível com a Constituição de 1988, com os compromissos internacionais assumidos pelo Brasil e, principalmente, com os interesses do país. Hoje, as dinâmicas socioeconômicas se impõem como catalisadores de uma atualização 
progressiva das normas, a fim de possibilitar atração de mão-de-obra e a defesa dos direitos humanos dos migrantes.

Segundo Lopes (2009, p. 568), a existência de um regime jurídico especial para estrangeiros é correlata à existência de um regime sancionador. No Estatuto do Estrangeiro estão previstas as punições para o descumprimento da legislação migratória, que resultam na retirada compulsória do estrangeiro do território nacional, entre as quais destacam-se a deportação e a expulsão.

A deportação consiste na sanção imposta pelas autoridades competentes em razão da constatação da entrada ou estada irregular, principalmente no que se refere ao exercício de trabalho irregular. Outro fator que enseja a deportação é a decisão do Ministério da Justiça, a cargo da Polícia Federal, com base em critérios de periculosidade e/ou nocividade ao interesse nacional, acerca da conveniência de impedir a entrada do estrangeiro mesmo que este disponha de visto concedido pela autoridade consular. O procedimento pode ainda envolver a aplicação de multa e se estender aos membros da família do impedido.

Em alguns casos, o estrangeiro tem direito à retirada voluntária; em outros, o processo de deportação pode sujeitar o deportando à prisão de até 60 dias prorrogáveis por igual período. A deportação é medida discricionária da Polícia Federal. Por fim, o estrangeiro que for deportado ficará devendo ao Brasil os custos com a deportação, e só poderá retornar legalmente ao país após o ressarcimento (LOPES, 2009, pp. 570-571).

Já a expulsão tem caráter mais severo e é aplicada nos casos em que o estrangeiro atentar contra a segurança nacional, sendo discricionária do Presidente da República, que deverá sancioná-la ou revogá-la por decreto. As disposições sobre a expulsão encontram-se no art. 65 da Lei no 6.815/80.

Art. 65. É passível de expulsão o estrangeiro que, de qualquer forma, atentar contra a segurança nacional, a ordem política ou social, a tranqüilidade ou moralidade pública e a economia popular, ou cujo procedimento o torne nocivo à conveniência e aos interesses nacionais. (Renumerado pela Lei no 6.964, de 09/12/81)

Parágrafo único. É passível, também, de expulsão o estrangeiro que:

a) praticar fraude a fim de obter a sua entrada ou permanência no Brasil;

b) havendo entrado no território nacional com infração à lei, dele não se retirar no prazo que lhe for determinado para fazê-lo, não sendo aconselhável a deportação;

c) entregar-se à vadiagem ou à mendicância; ou

d) desrespeitar proibição especialmente prevista em lei para estrangeiro. 
Com a expulsão, o estrangeiro fica impossibilidade de retornar ao Brasil, pois o retorno é crime tipificado no Código Penal. Para Lopes (2009), a legitimidade da expulsão é inquestionável em relação à pratica de crimes comuns, mas não caberia nos casos em que o imigrante se encontre em situação documental (imigratória) irregular. A autora chama atenção para o fato de que a expulsão é sanção de grande ofensividade, razão pela qual normas internacionais, como o Pacto Internacional de Direitos Civis e Políticos e o Pacto de São José da Costa Rica, preveem a garantia do devido processo legal/administrativo, com direito à ampla defesa (incluindo recursos) e a vedação de expulsões coletivas (LOPES, 2009, p. 572).

Não é somente na discricionariedade das medidas sancionatórias que reside a crítica das entidades defensoras dos direitos humanos dos migrantes e estudiosos ao Estatuto do Estrangeiro. Na visão de Ventura e Reis (2014), as suas principais características são "o alto grau de restrição e burocratização da regularização migratória, a discricionariedade absoluta do Estado, a restrição dos direitos políticos e da liberdade de expressão, além de explícita desigualdade em relação aos direitos humanos dos nacionais".

Alguns exemplos mais significativos dessa discriminação podem ser encontrados nos artigos do Estatuto do Estrangeiro referentes às manifestações culturais dos estrangeiros e aqueles que tratam da naturalização. Conforme o art. 107, "é lícito aos estrangeiros associarem-se para fins culturais, religiosos, recreativos, beneficentes ou de assistência, filiarem-se a clubes sociais e desportivos, e a quaisquer outras entidades com iguais fins, bem como participarem de reunião comemorativa de datas nacionais ou acontecimentos de significação patriótica." Entretanto, pelo art. 110, todas essas manifestações poderão ser impedidas caso o Ministro da Justiça julgue conveniente aos interesses nacionais.

Milesi (2007) chama atenção para outras questões que não são contempladas pela legislação em vigor e que ensejam tratamento adequado, tais como:

- pais estrangeiros que, tendo um filho brasileiro, e que, por descuido ou falta de condições, não promoveram o processo de permanência; passados alguns anos, o filho venha a falecer; pelo espírito frio da lei, extingue-se, para estes pais, o direito de obterem a permanência no Brasil, pois já não existe a condição de dependência econômica do filho ou filha brasileira.

- estrangeiros que, após anos de casamento, na hipótese de não haverem realizado o pedido de permanência, com a separação extingue-se para o 
cônjuge estrangeiro o direito de promovê-la, devendo, pela legislação vigente, deixar o País onde já estabeleceu todos os seus vínculos e relações.

- pessoas que, em algum momento, poderiam abrigar-se ao instituto do refúgio, mas que, por uma razão ou outra, já não podem ou não é o caso de serem contempladas com esta proteção.

- emergências em função de catástrofes naturais ou calamidades que demandam a acolhida e uma solução legal, temporária ou permanente, por razões humanitárias e de solidariedade. ${ }^{15}$

- a proteção aos direitos dos trabalhadores e trabalhadoras migrantes, inclusive prevendo a possibilidade de o estrangeiro participar da administração ou representação de sindicato ou associação profissional.

- o combate à xenofobia e aos crimes contra os imigrantes e, quando for o caso, contra sua condição de trabalhadores.

- a proteção e assistência de vítimas do tráfico de pessoas, traduzidas na proteção da identidade, assistência legal (com acesso a informações em seu próprio idioma), recuperação física, psicológica e social, garantia de segurança física, entre outros.

- a revisão profunda da parte relativa às vedações impostas aos imigrantes e da normativa referente às medidas de afastamento compulsório do País.

A intensificação dos fluxos migratórios entre os países, por motivos econômicos, conflitos étnicos ou desastres naturais, tem contribuído diretamente para o aumento das leis domésticas sobre migrações internacionais e para que muitos países repensem ou finalmente sistematizem suas políticas migratórias. Em que pese a dificuldade de uma reforma mais ampla da principal norma sobre as migrações no Brasil, em 14 anos, as normas brasileiras sobre migrações chegam em número próximo àquelas de todo $\mathrm{o}$ século XX somadas, o que denota uma maior preocupação jurídica com a regulamentação dos temas afetos aos imigrantes no Brasil (CLARO, 2014). Em recente trabalho de compilação das normas já editadas no Brasil sobre as migrações, a pesquisadora Carolina Claro, da Universidade de Brasília, apurou que, desde o ano 2000

\footnotetext{
${ }^{15}$ Preserva-se a menção feita pela autora, com a ressalva de que, em 2012, a imigração haitiana forçou a tomada de medidas contingenciais posteriormente incorporadas à legislação (Resolução Normativa CNIg no 97, de 12/01/2012).
} 
até agosto de 2014, já foram editadas 132 normas $^{16}$, sendo 14 leis (Leis ordinárias, Decretos ou Emendas Constitucionais), 22 Portarias (Ministério do Trabalho e Emprego, Ministério da Justiça e Secretaria Nacional de Justiça) e 96 Resoluções (CNIg e CONARE). Em seu estudo, a autora conclui que

[m]esmo que a grande maioria das 132 normas existentes desde o ano 2000 seja em forma de resoluções de órgãos colegiados (CNIg e CONARE) ou portarias ministeriais, o que importa notar é que: (i) diante de uma legislação migratória defasada, os órgãos administrativos são levados à legislar sobre as lacunas jurídicas, especialmente diante de novas situações e fluxos migratórios, e (ii) a demanda crescente e específica das migrações internacionais no Brasil tem requerido novas disposições normativas de amparo aos estrangeiros (CLARO, 2014, p. 147).

Fica evidenciado, portanto que a legislação migratória em vigor carece de atualização, pois conflita com os princípios consignados na Constituição Federal e os principais tratados de direitos humanos firmados pelo Brasil. Além disso, a inconsistência da legislação de 1980 é apontada como um ponto fraco das demandas do Estado brasileiro para tratar a questão dos emigrantes brasileiros em negociações e fóruns bilaterais e multilaterais (REIS, 2011, p. 59).

Conforme o discurso oficial, o Brasil não pode ser apontado como um país que vincula a entrada irregular no território nacional à legislação de direito penal. De acordo com o Ex-Secretário-Executivo do Ministério da Justiça e então presidente do Comitê Nacional para Refugiados (Conare), Luiz Paulo Barreto, “o Brasil jamais realizou prisões de ilegais (sic) e deportações em massa" (BARRETO, 2012). Não haveria, portanto, intenção do Estado brasileiro no sentido de levantar barreiras à imigração. Essa postura aponta caminho inverso ao trilhado pelos Estados Unidos e pela Europa. Segundo Lessa (2009, p. 9), "a tendência que se tem verificado é a da criminalização da migração, com a autonomização dos órgãos de controle e a sua conversão em organismos policiais."

Patarra (2005) aborda o tema das migrações internacionais na perspectiva dos direitos humanos, enfocando aspectos de governança e defendendo a discussão de políticas migratórias vinculadas às políticas econômicas e comerciais. Em artigo de 2005, a autora já observava a nova dinâmica da imigração, reconhecendo a

\footnotetext{
${ }^{16}$ Entre os principais temas tratados pelas normas sobre migrações editadas entre 2000 e 2014, destacamse: i) vistos para estrangeiros e seus procedimentos; ii) documentos relativos ao estrangeiro no Brasil; iii) anistia migratória; iv) procedimentos relativos à solicitação de reconhecimento da condição de refugiado; v) nacionalidade brasileira - aquisição ampliada do jus sanguinis; e vi) organização dos órgãos da Administração Pública Federal competentes para tratar das migrações internacionais no Brasil (CLARO, 2014, p. 148).
} 
urgência de tratamento de uma problemática emergente que demanda análise, entendimento e monitoramento. Isso significa reformulação e ampliação das políticas e ações frente à nova situação, para alterar seus pressupostos, tomar em conta as especificidades dos fluxos e dos grupos sociais envolvidos, defender os indivíduos de atravessadores, ampliar seu escopo para dar conta dos direitos humanos dos migrantes e suas famílias.

Iniciativas para uma revisão da política migratória brasileira vêm sendo discutidas desde 2005, com a realização de seminários e debates, tanto em âmbito de governo como da sociedade civil. Foi lançado, em 2010, um documento de consulta com vistas à elaboração de uma nova "Política Nacional de Imigração e Proteção ao(à) Trabalhador(a) Migrante". Nele estão registrados princípios, diretrizes e ações que deverão nortear a elaboração da política em tela.

Para os fins desta política consideram-se Direitos Humanos o conjunto de direitos civis, políticos, econômicos, sociais e culturais, dentre outros, e de liberdades fundamentais, que são universais, indivisíveis e invioláveis, correspondentes às necessidades essenciais de todas as pessoas, que são iguais para todos e que devem ser atendidos para que as pessoas possam viver com dignidade (BRASIL, 2010a).

O objetivo é estabelecer princípios, diretrizes, estratégias, ações em relação aos fluxos migratórios internacionais, com vistas a orientar as entidades e órgãos brasileiros na atuação vinculada ao fenômeno migratório, a contribuir para a promoção e proteção dos Direitos Humanos dos migrantes e a incrementar os vínculos das migrações com o Desenvolvimento (BRASIL, 2010a).

A preocupação com a adoção de medidas de proteção aos direitos humanos envolvendo ações de combate ao tráfico de pessoas, à discriminação, à xenofobia e ao racismo - e com a inclusão social do imigrante constituem premissas importantes para uma postura mais ativa do Estado brasileiro em relação ao tema.

A busca por um novo posicionamento frente à questão das migrações internacionais se apresenta de forma muito clara em alguns dos princípios elencados no referido documento, quais sejam, o de que "a imigração indocumentada ou irregular constitui infração administrativa, e não está sujeita à sanção penal", e "as políticas de desenvolvimento, em âmbito nacional, regional e local, deverão considerar as migrações de forma a maximizar seus efeitos positivos". Tal discurso parece indicar que, ao contrário de países que vêm tratando a imigração irregular como crime, com prisões e deportações de trabalhadores indocumentados, o Brasil aborda a questão de forma mais coerente com seu histórico de receptor de fluxos de imigração, com tendência a 
favorecer a inclusão do estrangeiro que busca melhores condições de vida no País.

A evidente desatualização do Estatuto do Estrangeiro levou o governo brasileiro a elaborar uma nova proposta de lei de migrações, que passou a incluir a expressão “direitos humanos" ${ }^{17}$. Entretanto, o projeto da nova Lei de Imigração e Naturalização (PL no 5.655, de 2009) ainda mantém muitos traços da legislação vigente, permanecendo no texto a ideia da segurança nacional e, com ela, toda a burocracia e discricionariedade que decorre do controle permanente dos estrangeiros: o paradigma do estrangeiro conserva-se frente às reivindicações de tratamento dos indivíduos como cidadãos migrantes. ${ }^{18}$ (BARALDI, 2011)

Enquanto não ocorre a substituição do Estatuto do Estrangeiro por um arcabouço jurídico mais alinhado com a ordem democrática vigente, a legislação migratória vem sendo atualizada com base nas Resoluções Normativas (RN) do Conselho Nacional de Imigração e pelas Leis de Anistia Migratória. A primeira das 115 RNs do CNIg data de 1997, e a média é de 6 RNs editadas por ano.

Diante da necessidade de regularizar um expressivo contingente de imigrantes irregulares, três anistias foram realizadas no Brasil, a primeira em 1988, conforme referido no item 2.2 supra (p. 51); a segunda, em 1998; e a mais recente, em 2009. A Lei no 11.961, de 2 de julho de 2009, faculta o requerimento de residência provisória ao estrangeiro que, tendo ingressado no território nacional até 1o de fevereiro de 2009, nele permaneça em situação migratória irregular.

Com isso, cerca de 42 mil pessoas puderam regularizar sua condição migratória, assegurando direito de trabalhar e ter acesso a saúde e educação públicas e à Justiça. Os maiores grupos beneficiados pela medida incluíram 16.881 bolivianos, 5.492 chineses, 4.642 peruanos, 4.135 paraguaios e 1.129 coreanos. Além desses grupos, buscaram a regularização 2.390 europeus (ingleses, franceses, italianos e alemães) e 2.700 africanos (ESTADO, 2010) de diversas nacionalidades.

\footnotetext{
${ }^{17}$ Conforme os seguintes artigos do PL no 5.655/2009, em tramitação na Câmara dos Deputados: "Art. 2o - A aplicação desta Lei deverá nortear-se pela política nacional de migração, garantia dos direitos humanos, interesses nacionais, socioeconômicos e culturais, preservação das instituições democráticas e fortalecimento das relações internacionais." e "Art. 3o- A política nacional de migração contemplará a adoção de medidas para regular os fluxos migratórios de forma a proteger os direitos humanos dos migrantes, especialmente em razão de práticas abusivas advindas de situação migratória irregular."

${ }^{18}$ Ao tempo da elaboração desta pesquisa, além do PL no 5.655/2009 (Câmara dos Deputados), encontrase em tramitação o PLS no 288/2013 (Senado Federal), e estão pendentes de envio ao legislativo federal a Proposta de Substitutivo ao PL no 5.655/2009, elaborada pela Comissão de Especialistas criada pelo Ministério da Justiça, e a Proposta de Lei sobre Apatridia, elaborada conjuntamente entre o Ministério da Justiça e organismos internacionais de migrações, como ACNUR e OIM, e outros atores governamentais e não governamentais que tratam da matéria (CLARO, 2014).
} 
Esse quadro revela a persistência do problema da imigração irregular ao longo dos anos e a necessidade de políticas mais abrangentes para tratar da questão.

Se, por um lado, as anistias demonstram a "boa vontade" oficial para lidar com a questão dos indocumentados, por outro lado revelam a persistência do problema ao longo dos anos e a necessidade de uma política mais abrangente. Idealmente, com a implementação dos acordos de livre circulação e a nova legislação de estrangeiros, o número de indocumentados no país deve cair. (REIS, 2011).

Apesar de conferir direitos aos migrantes e atualizar situações migratórias irregulares, essas medidas constituem intervenções pontuais e paliativas, que não eliminam os problemas gerados pela falta de estrutura do Estado brasileiro para tratar o tema das migrações internacionais e pela ausência de definição de uma política migratória menos vinculada à finalidade laboral e à segurança nacional e mais alinhada com os direitos humanos e a democracia.

\subsection{Atuação dos órgãos de governo envolvidos em temas migratórios}

No Brasil, a formulação e a execução da política migratória envolve a articulação dos Ministérios da Justiça, das Relações Exteriores e do Trabalho. Cada um desses órgãos possui unidades responsáveis pelas atividades relacionadas à aplicação da legislação no que se refere ao controle dos movimentos migratórios, a fiscalização, a emissão de documentos. Além de ações procedimentais, os órgãos também interagem na revisão de instrumentos normativos, bem como na discussão sobre as necessárias alterações da política migratória e a elaboração de propostas de lei e decretos a serem submetidas à análise do Chefe do Poder Executivo e do Congresso Nacional. No âmbito do Ministério da Justiça (MJ), as atividades relacionadas às migrações estão concentradas no Departamento de Estrangeiros (DEEST) da Secretaria Nacional de Justiça (SNJ) e no Departamento de Polícia Federal (DPF). No Ministério das Relações Exteriores (MRE), no Departamento de Imigração e Assuntos Jurídicos (DIJ) e sua Divisão de Imigração (DIM). E, por fim, no Ministério do Trabalho e Emprego (MTE), na sua Coordenação-Geral de Imigração (CGIg) e no Conselho Nacional de Imigração (CNIg), órgão colegiado que conta com a participação de representantes de diversos outros ministérios e representantes da sociedade civil.

Passaremos, agora, à descrição das principais atribuições de cada órgão. 


\subsubsection{Ministério da Justiça e Polícia Federal}

Ao Ministério da Justiça cabe a análise de requerimentos de extensão de vistos de permanência e naturalização, a análise de pedidos de refúgio no âmbito do Conselho Nacional para Refugiados - CONARE, entre outras atividades, o controle das fronteiras, por meio da Polícia Federal,

O Departamento de Estrangeiros (DEEST), vinculado à Secretaria Nacional de Justiça, trata dos assuntos relacionados à nacionalidade, naturalização e regime jurídico dos estrangeiros. Cabe ao DEEST analisar os processos de permanência de estrangeiros no território nacional, de naturalização e de retiradas compulsórias de estrangeiros do território nacional com o cumprimento de medidas administrativas ou judiciais, ordinariamente instruídos nas unidades descentralizadas do Departamento de Polícia Federal (DPF), são encaminhados ao MJ para decisão ministerial e direcionados ao DEEST. Também integra a estrutura do Ministério da Justiça o Comitê Nacional para Refugiados - CONARE ${ }^{19}$, cuja atuação é relevante acerca da regulamentação e do processamento de solicitações de refúgio no Brasil.

\subsubsection{Ministério do Trabalho e Conselho Nacional de Imigração}

O Ministério do Trabalho é o órgão federal responsável pela concessão da autorização de trabalhos aos estrangeiros, mantendo em sua estrutura: a CoordenaçãoGeral de Imigração (CGIg), responsável pela operacionalização dos processos de solicitação de vistos de trabalho com o apoio das unidades das Superintendências Regionais do Trabalho em todo o país; e o Conselho Nacional de Imigração (CNIg), sendo este um órgão colegiado quadripartite, envolvendo representantes de diversos órgãos públicos, dos empregadores, das centrais sindicais e da sociedade civil, responsável, entre outras atribuições, por formular políticas de imigração e por opinar a respeito de propostas de alteração da legislação relativa à imigração. ${ }^{20}$

O CNIg foi criado pela Lei no 6.815 , de 19 de agosto de 1980, com organização e funcionamento definidos pelos Decretos no 840, de 22 de junho de 1993, e n- 3.574,

\footnotetext{
${ }^{19}$ O CONARE é composto por um representante dos seguintes órgãos e entidades: Ministério das Relações Exteriores; Ministério da Saúde; Ministério do Trabalho e Emprego; Ministério da Educação; Departamento de Polícia Federal; Cáritas Arquidiocesana do Rio de Janeiro e São Paulo; e Alto Comissariado das Nações Unidas para Refugiados (ACNUR).

${ }^{20}$ A composição do CNIG encontra-se no Apêndice D.
} 
de 23 de agosto de $2000^{21}$. O CNIg vem atualizando e tornando mais protetiva a legislação migratória por meio de portarias e resoluções, entre as quais a Resolução Normativa no 93/2010, que disciplina a concessão de visto permanente ou permanência no Brasil a estrangeiro considerado vítima do tráfico de pessoas e a Resolução Normativa n- 77/2008, que dispõe sobre critérios para a concessão de visto temporário ou permanente, ou de autorização de permanência, ao companheiro ou companheira, em união estável, sem distinção de sexo.

Entre as muitas Resoluções Normativas do CNIg, podem ser citadas, ainda, a Resolução Normativa no 6 , de 21/08/1997, que regula a concessão de permanência definitiva a asilados ou refugiados e suas famílias; a Resolução Normativa no 93, de 21/12/2010, que disciplina a concessão de visto permanente ou permanência no Brasil a estrangeiro considerado vítima do tráfico de pessoas; a Resolução Normativa no 97, de 12/01/2012, que dispõe sobre a concessão do visto permanente previsto no art. 16 da Lei no 6.815 , de 19 de agosto de 1980, a nacionais do Haiti (visto permanente por razões humanitárias), prorrogada pela Resolução Normativa nº 106, de 246/104/2013; e a Resolução Normativa no 108 , de 12/02/2014, que dispõe sobre a concessão de visto temporário ou permanente e permanência definitiva a título de reunião familiar.

\subsubsection{Ministério das Relações Exteriores}

O Ministério das Relações Exteriores (MRE) mantém em sua estrutura o Departamento de Imigração e Assuntos Jurídicos (DIJ), o qual também é integrado pela Divisão de Imigração (DIM). O DIJ é responsável pelo controle da emissão de vistos de entrada concedidos pelas repartições consulares brasileiras no exterior e pela legalização de documentos no Brasil, entre outras atividades. O MRE atua por meio da rede consular no exterior pela emissão de vistos e na coordenação de processos de regularização de documentos necessários à permanência do estrangeiro em território

\footnotetext{
${ }^{21}$ O Decreto no 840 , de 22 de junho de 1993, definiu as seguintes competências do CNIg: I - Formular a política de imigração; II - Coordenar e orientar as atividades de imigração; III - Efetuar o levantamento periódico das necessidades de mão-de-obra estrangeira qualificada, para admissão em caráter permanente ou temporário; IV - Definir as regiões de que trata o art. 18 da Lei no 6.815 , de 19 de agosto de 1980, e elaborar os respectivos planos de imigração; V - Promover ou fornecer estudos de problemas relativos à imigração; VI - Estabelecer normas de seleção de imigrantes, visando proporcionar mão-de-obra especializada aos vários setores da economia nacional e captar recursos para setores específicos; VII Dirimir as dúvidas e solucionar os casos omissos, no que diz respeito a imigrantes; VIII - Opinar sobre alteração da legislação relativa à imigração, quando proposta por qualquer órgão do Poder Executivo; IX - Elaborar seu regimento interno, que deverá ser submetido à aprovação do Ministro de Estado do Trabalho.
} 
nacional. Além disso, o MRE realiza, no plano internacional, as negociações de acordos sobre isenção ou dispensa de vistos com outros Estados, como no caso do Mercosul e de países que oferecem reciprocidade nos assuntos referentes à entrada, permanência e retirada compulsória de estrangeiros.

Além das entidades governamentais envolvidas na formulação e execução da política migratória, caberia citar a Comissão Nacional de População e Desenvolvimento (CNPD), que também atua na reflexão acerca das políticas públicas que abrangem o tema das migrações. A CNPD foi criada em 1995 após a Conferência do Cairo de 1994 sobre População e Desenvolvimento e atualmente está vinculada à Secretaria de Assuntos Estratégicos da Presidência da República.

Apresentados os principais atores no âmbito governamental a cargo da formulação e execução da política migratória, importante para as discussões sobre a política migratórias que se farão mais adiante, passamos à discussão do amplo espectro de abrangência das políticas públicas para as migrações.

\subsection{Migrações e políticas públicas}

Pensar as políticas públicas para as migrações envolve considerar aspectos do desenvolvimento humano em sentido mais amplo do que a mera contabilização de fluxos. Atualmente, já se caminha para aceitação de que as migrações não são questões apenas de segurança nacional ou de segurança pública, mas temas que exigem soluções de gestão por parte dos governos.

Apesar de constituir episódio ocorrido além do período da pesquisa, vale comentar a reação dos órgãos executores da política migratória ao caso do repentino aumento no fluxo de imigrantes haitianos. Essa pequena digressão se justifica por ser exemplo da atuação do CNIg diante de uma contingência que requereu solução não prevista pelo Estatuto de Estrangeiro: o "visto humanitário".

Após o terremoto ocorrido em 12 de janeiro de 2010, houve a destruição de grande parte da infraestrutura do Haiti. A capital, Porto Príncipe, teve arrasada uma importante parcela de edificações, incluindo hospitais, escolas, hotéis, residências e o presídio. Pouco após o abalo, disseminou-se rapidamente uma epidemia de cólera, com 
saldo significativo de vítimas. ${ }^{22}$ A agitação social decorrente dessas catástrofes foi administrada pela Missão das Nações Unidas para a Estabilização do Haiti $(\text { MINUSTAH })^{23}$, responsável por prestar assistência aos feridos e desabrigados, garantir a segurança pública e coordenar projetos de reconstrução.

Em 2011, haitianos começaram a ingressar no Brasil pela cidade de Assis BrasilAC, na fronteira com a Bolívia, de onde seguiram para Brasileia-AC. Segundo reportagem do jornal O Globo (CARVALHO, 2012), o primeiro grande grupo de haitianos, formado por 140 pessoas, chegou a Brasileia no dia 14 de janeiro de 2011. Muitos haitianos solicitaram refúgio na condição de desalojados por desastres naturais. O Ministério da Justiça (MJ), entretanto, segue a orientação de analisar como pedidos de "refúgio" somente os motivados por perseguição política. ${ }^{24}$ Por isso, o MJ decidiu converter essas solicitações em pedidos de residência, e informou que "ao todo, 593 haitianos já foram beneficiados com a residência permanente, sob critério humanitário". (BRASIL, 2012)

Em 12 de janeiro de 2012, o Conselho Nacional de Imigração (CNIg) aprovou a Resolução Normativa no 97, que disciplina a concessão de vistos permanentes ${ }^{25} \mathrm{em}$ caráter humanitário para os haitianos. Com essas medidas, o governo buscou regularizar a situação daqueles que já se encontravam em território nacional, ao mesmo tempo em que agiu no sentido de estruturar uma política pública para dispensar o tratamento adequado a futuros pedidos de vistos de permanência.

A menção ao episódio envolvendo os haitianos não é gratuita. Para Ventura \& Iles (2012), apesar de não ser representativo da realidade migratória brasileira, serviu como laboratório das vicissitudes do "ser potência", e a grande notoriedade do caso serviu como um pretexto constrangedor, mas eficaz. A adoção de uma política ad hoc

\footnotetext{
${ }^{22}$ Em 30 de novembro de 2011, a Organização Mundial de Saúde (OMS) registrava acumulado de 515.699 casos notificados de cólera no Haiti, com 279.077 vítimas hospitalizadas e 6.942 óbitos. Fonte: OMS (2011).

${ }^{23}$ A MINUSTAH conta com a participação de efetivos militares de 20 países e foi instituída pela Resolução 1542 do Conselho de Segurança das Nações Unidas em 2004. Pelo seu histórico de engajamento em operações de paz, o Brasil foi convidado a assumir o comando da vertente militar da missão. O País vem contribuindo para a reconstrução do Haiti com recursos humanos e financeiros na estruturação de projetos de infraestrutura e cooperação nas áreas de têxteis e biocombustíveis.

${ }^{24}$ À luz da Convenção de Genebra de 1951 e da legislação brasileira pertinente (Lei no 9.474, de 22 de julho de 1997), o que determina a elegibilidade para concessão de refúgio é a saída de um indivíduo do país de sua nacionalidade em decorrência de perseguição política, étnica ou religiosa, com fundados temores de ameaça à sua vida, sendo esse perigo tão iminente que o impeça de retornar.

25 "Ao estrangeiro que recebe o status de permanente no Brasil é assegurado o exercício dos mesmos direitos civis, liberdades sociais, culturais e econômicas dos brasileiros, em particular o direito ao trabalho e à livre iniciativa, além do acesso à justiça, inclusive a gratuita, à saúde, à educação, e aos direitos advindos das relações de trabalho e emprego, entre outros".
} 
foi a saída encontrada pelas autoridades para equacionar o problema.

A situação apresentada é pontual, mas demonstra como o fenômeno migratório vem afetando a sociedade brasileira e também os órgãos de governo. Além dos haitianos em tempos recentes, pessoas de diversas nacionalidades têm buscado o visto permanente no Brasil. Nesse contexto, a formulação de políticas públicas para lidar com esses contingentes populacionais é de importância crucial para o País. Não apenas no campo doméstico, mas no que se refere à projeção internacional do Brasil, o tema cresceu em importância ao longo dos últimos 10 anos.

Em paralelo, o Brasil convive com uma legislação ultrapassada no que respeita às questões migratórias. Ao mesmo tempo, espera obter dos países que acolhem fluxos importantes de emigrantes brasileiros o tratamento digno e medidas que viabilizem sua integração. Segundo afirma Lessa (2009, p. 7),

\begin{abstract}
para os governos dos países latino-americanos, a nova sensibilidade política que cerca o tema da imigração nos polos de atração tem motivado, com maior ou menor intensidade, a adoção de políticas para a proteção dos interesses dos seus súditos migrantes. Conferências regionais latino-americanas têm sido convocadas com o intuito de se constituir espaços de reflexão, cooperação e de construção de consensos entre os governos.
\end{abstract}

A fim de compreender os impactos causados pelas migrações internacionais para o Brasil e os fluxos de brasileiros para o exterior, a Secretaria de Assuntos Estratégicos da Presidência da República e o Centro de Gestão e Estudos Estratégicos (CGEE) elaboraram o estudo "População e políticas sociais no Brasil: os desafios da transição demográfica e das migrações internacionais" (CGEE, 2008). O estudo contou com a colaboração de pesquisadores do Centro de Desenvolvimento e Planejamento Regional da Universidade Federal de Minas Gerais (CEDEPLAR/UFMG) e do Núcleo de Estudos de População da Universidade Estadual de Campinas (NEPO/Unicamp). Já na Introdução da obra, os autores apontavam que a nova etapa da economia mundial, caracterizada pelo aumento dos fluxos de capitais e de populações, exige que países como o Brasil passem a conviver com a saída de nacionais e a receber novos fluxos de migrantes estrangeiros, entrando na rota das migrações internacionais contemporâneas

As recomendações referentes às migrações internacionais ancoram-se, de um lado, em políticas migratórias voltadas para os Direitos Humanos e, de outro, nas remessas dos emigrantes como fator positivo para diminuição da pobreza nos países de origem. E, portanto, na governabilidade das migrações internacionais que o tema deve ser aprofundado, para que se contemple de maneira adequada a dimensão institucional e as possíveis "brechas" que poderão possibilitar a diminuição das penosas condições dos emigrantes brasileiros (CGEE, 2008, p. 15). 
Na visão de Rosana Baeninger e Fausto Brito, as migrações internacionais requerem atenção especial por parte de estudiosos e formuladores de políticas no Brasil, no sentido de desenvolvimento de políticas sociais voltadas tanto para o contingente migrante nos locais de destino e de origem, quanto para políticas de governabilidade dessas migrações (CGEE, 2008, p. 332).

No caso dos fluxos de emigrantes, na visão dos especialistas, as políticas migratórias precisam ser pensadas considerando: 1) políticas conjuntas com países receptores e expulsores; 2) possibilidade de conter na origem a "indústria da migração ilegal"; 3) apoio consular nos países receptores; 4) conhecimento dos fluxos migratórios e das principais questões emergentes; 5) políticas de emprego em âmbito nacional que permita a inserção do potencial emigrante; 6) garantia dos direitos humanos para os contingentes migrantes (CGEE, 2008).

Por fim, o relatório do CGEE chama atenção para a necessidade de se contemplar os migrantes refugiados nas políticas a serem elaboradas. O Brasil é parte da Convenção das Nações Unidas de 1951 sobre o Estatuto dos Refugiados e do seu Protocolo de 1967. A Lei no 9.474/97 contempla os principais instrumentos regionais e internacionais sobre o tema. A lei adota parcialmente a definição ampliada de refugiado estabelecida na Declaração de Cartagena, de 1984, considerando a "violação generalizada de direitos humanos" como uma das causas de reconhecimento da condição de refugiado. Em maio de 2002, o Brasil ratificou a Convenção das Nações Unidas de 1954 sobre o Estatuto dos Apátridas e, posteriormente, em outubro de 2007, a Convenção da ONU de 1961 para Redução dos Casos de Apatridia.

No âmbito dessas evidências e complexidade do panorama das migrações internacionais no Brasil, a fim de subsidiar políticas e a governabilidade das migrações internacionais, segundo os especialistas do CGEE, é preciso que se considerem os seguintes aspectos:

(1) os processos, fluxos e grupos sociais envolvidos nos deslocamentos internacionais são muito distintos de um para outro destino e origem da migração; trata-se de considerar políticas migratórias para diferentes públicos-alvo: mulheres, jovens, não-documentados, documentados, refugiados, fronteiras, migração sul-norte, migração sul-sul, migração familiar, migração individual, dentre tantas outras especificidades;

(2) a complexa relação entre migração e cidadania, tanto para os indivíduos migrantes, quanto para os Estados nacionais. Do ponto de vista dos migrantes, que essa cidadania contemple os direitos humanos, incluindo-se gênero, raça e etnia. Do ponto de vista dos Estados, essa cidadania envolve também as relações internacionais e interesses de Estado nas estratégias e leis migratórias;

(3) as comunidades estrangeiras (redes) territorializadas buscam criar ou manter uma identidade, o que gera xenofobias, preconceitos e intolerâncias; 
(4) os volumes da migração internacional serão crescentes (Fundo de População das Nações Unidas); concentrados em determinados lugares; de longa e curta distância, predominantemente de países pobres para países ricos, entre países pobres e entre países em desenvolvimento;

(5) que da agenda da Segurança Nacional, a migração internacional passe a fazer parte da agenda da Integração Regional;

(6) no contexto de Integração Regional, o tema das fronteiras merece um recorte específico, tanto pela diversidade da fronteira, quanto pelo papel que desempenha na dinâmica local, sugerindo acordos bilaterais que sustentem e viabilizem a histórica relação entre as fronteiras internacionais;

(7) a migração de refugiados passa a fazer parte da política migratória internacional do Brasil, aumentando a pressão para o reassentamento de refugiados e para o acolhimento de novos contingentes;

(8) as organizações não-governamentais voltadas para os direitos e assistência dos migrantes - no Brasil entidades confessionais (pastorais, scalabrinianos), que conhecem desde o cotidiano desses migrantes estrangeiros até os fluxos que passam a emergir em determinados momentos; (9) as restrições ao trabalhador migrante nos países de destino expõem esse contingente a exploração e más condições de vida, o que reforça a necessidade de apoio institucional;

(10) as remessas de recursos internacionais constituem, do ponto de vista individual, o "retorno provisório" do migrante; do ponto de vista econômico, "divisas de povos invisíveis".

(11) para subsidiar a formulação de políticas de forma consistente, é preciso que o país conte com um Sistema Integrado de Informações sobre Migrações Internacionais, contemplando os bancos de dados do Ministério do Trabalho, da Polícia Federal e do CONARE (CGEE, p. 340-341).

A transcrição dessas recomendações se justifica por encontrar acolhida em formulações de diversos autores acerca das necessárias atualizações da política migratória brasileira (RAMOS et al,, 2014; MILESI, 2007; MARTES, 2010), opinião compartilhada por este trabalho.

Em 2008, foi realizado o seminário "Diálogo Tripartite sobre Políticas Públicas de Migração para o Trabalho", organizado pelo MTE e pela OIT. Ao final do evento, foram elencadas recomendações gerais com vistas ao desenvolvimento de um plano de ação para uma gestão ordenada das migrações.

1. É urgente a adoção de uma nova Lei que discipline a temática migratória de forma coerente com a atual Constituição Federal brasileira, haja vista que a norma em vigor não está pautada nos direitos humanos das(os) migrantes e tampouco contempla a temática da emigração;

2. A legislação brasileira, em especial o anteprojeto de lei que substituirá o atual Estatuto do Estrangeiro (Lei 6.815/1980), doravante denominado "APL Migrações", necessita ser adequada aos instrumentos internacionais de proteção à trabalhadora e ao trabalhador migrante e suas famílias;

3. As políticas migratórias devem adotar como paradigma a proteção às trabalhadoras e aos trabalhadores migrantes e suas famílias, com especial atenção à situação da mulher, das crianças e dos adolescentes;

4. É preciso considerar a centralidade da temática do trabalho no que concerne ao fenômeno migratório, bem como a importância do social no estabelecimento de políticas públicas voltadas às migrações;

5. É necessária a simplificação dos procedimentos burocráticos relativos a migrantes e qualificação de servidores públicos para um adequado atendimento às trabalhadoras e trabalhadores migrantes e suas famílias; 
6. É necessário produzir informações estatísticas e estudos qualificados que apreendam as especificidades do cotidiano das trabalhadoras e dos trabalhadores migrantes e das redes envolvidas;

7. Os acordos do MERCOSUL nas áreas migratória e trabalhista devem ser amplamente divulgados e conhecidos, visando a fortalecer a integração regional;

8. As políticas públicas voltadas à inserção de imigrantes no mercado de trabalho, bem como de brasileiras(os) que regressam do exterior, devem levar em consideração a necessidade de programas que atendam à multiplicidade e diversidade dos fluxos migratórios;

9. As políticas públicas de trabalho, emprego e renda devem prever estratégias específicas para as famílias de brasileiras(os) retornadas(os);

10. É preciso ampliar o acesso às políticas públicas de trabalho, emprego e renda nos territórios onde haja maior emigração de brasileiras(os);

11. É necessário realizar campanhas informativas e de esclarecimento sobre direitos e deveres de imigrantes, visando a favorecer a integração no Brasil, bem como sobre as providências necessárias para a migração laboral de cidadãs(ãos) brasileiras(os) ao exterior.

12. É necessário haver reflexão, esclarecimento e aplicação de linguagem adequada nas discussões sobre migração, evitando a utilização de termos com conotação de "criminalização" (BRASIL, 2008a, p. 3-5).

Ao final do encontro, houve a recomendação para que o Brasil ratificasse a Convenção n- 143 da OIT, de 1975, sobre as Imigrações Efetuadas em Condições Abusivas e Sobre a Promoção da Igualdade de Oportunidades e de Tratamento dos Trabalhadores Migrantes. A Convenção estabelece a garantia de igualdade de oportunidade e tratamento entre trabalhadores migrantes e nacionais. Com isso, os migrantes regularizados e com contrato de trabalho passarão a ter garantidos os mesmos direitos trabalhistas dos nacionais, como carteira assinada, recolhimento do FGTS (Fundo de Garantia do Tempo de Serviço), acesso à Previdência Social e filiação sindical, o que hoje é vedado pelo Estatuto do Estrangeiro (art. 106).

No quadro da globalização atual, observa-se uma tendência na direção de maior liberdade na circulação de mercadorias, serviços e capitais. Entretanto, a circulação de pessoas ainda sofre restrições, principalmente dos países que mais atraem migrantes. É certo que, em grande medida, os movimentos migratórios são motivados pela busca de melhores condições de vida, que se traduzem em acesso a moradia, emprego e renda, saúde e segurança. A ONU tem indicado, em relatórios sobre Migrações e Desenvolvimento, o importante papel do migrante para o desenvolvimento econômico tanto de seu país de origem, por sua capacidade de reduzir a pobreza de sua família no país de origem, de remessas internacionais, como do país de destino, pela dinamização da economia e da sociedade, por meio da ocupação de empregos que os nativos já não querem e por aumentar a população em países em processo de envelhecimento (ONU, 2006, 2013a, 2013c). 
Entretanto, o aumento do desemprego em determinado país geralmente resulta em pressão sobre as autoridades governamentais para limitar o ingresso de trabalhadores estrangeiros. Se, por um lado, os empregadores demandam recursos humanos estrangeiros para suprir necessidades específicas de suas empresas (não atendidas pela mão-de-obra local), por outro, o desemprego crescente faz com que a opinião pública - e especialmente os trabalhadores nativos - tenda a ver as migrações como um espectro negativo e ameaçador (COENTRO, 2011).

Por meio das políticas migratórias, o Estado exerce grande influência na organização dos fluxos migratórios. Além disso, é consenso entre os estudiosos que, nas sociedades regidas por Constituições democráticas, os direitos humanos asseguradas aos nacionais devem ser estendidas dos migrantes (MILESI, 2008; COENTRO, 2011; PATARRA, 2006). O que se tem visto, porém, é que os países desenvolvidos, têm criado fatores de inibição à entrada de migrantes com baixa qualificação. Esta orientação mais rígida das políticas migratórias tem levado muitos migrantes a buscarem alternativas informais para a entrada nos países-alvo, ocasionando o fortalecimento das redes de tráficos de pessoas. Essa tendência tende a se verificar em todos os países que praticarem políticas restritivas, conforme a visão de Ramos et al. (2014):

\footnotetext{
Propostas restritivas que abordam as migrações sob o prisma da segurança ou da seletividade econômica não contribuem para a diminuição dos fluxos, apenas para o incremento da vulnerabilidade dos migrantes. Políticas migratórias restritivas favorecem as redes de tráfico de pessoas e os intermediários na exploração de mão de obra, o que prejudica o mercado de trabalho e a sociedade em seu conjunto.
}

Nota-se que, quanto ao Brasil, que é signatário de convenções internacionais contra o crime organizado, em especial contra o tráfico de seres humanos, a adoção de políticas restritivas estaria em completo desacordo com as posições assumidas de defesa dos direitos humanos. As teorias migratórias que tratam da persistência dos fluxos migratórios no tempo apontam para o fato de que a tendência é de continuidade desses fluxos. Nesse sentido, verifica-se a relevância do estudo mais aprofundado das dinâmicas existentes entre a política externa e a política migratória no Brasil, a fim de potencializar as vantagens e minimizar as desvantagens das migrações para a inserção internacional do país e para a gestão do fenômeno migratório em nível doméstico.

Apresentadas essas considerações acerca das políticas públicas para as migrações, passamos à análise de sua formulação e execução, no intuito de identificar possíveis inter-relações com a política externa brasileira entre os anos de 1995 e 2010. 


\section{Capítulo 3: Pontos de contato entre a Política Externa e a Política Migratória}

Conforme a hipótese defendida por este trabalho, o cotejo das ações de política externa em relação à evolução da política migratória no período de 1995 a 2010 pode indicar pontos de contato entre as duas políticas. Embora a formulação e a execução de cada uma dessas políticas tenham uma dinâmica própria, é possível identificar objetivos comuns em termos da busca pelo desenvolvimento nacional e da promoção dos direitos humanos.

Observaremos neste capítulo alguns momentos em que esses objetivos estiveram alinhados tanto na política externa, quanto na política migratória, produzindo resultados marcantes do ponto de vista da funcionalidade das duas políticas tomadas em conjunto, isto é, situações em que a integração se mostrou vantajosa para avançar os objetivos de ambas. Serão também indicados alguns pontos dessa trajetória em que não se pode identificar uma relação direta de causalidade entre a política externa e a política migratória, ou essa relação se apresenta disfuncional, isto é, a integração das políticas não se revela de forma mais nítida e eficiente para avançar os objetivos de ambas.

\subsection{Principais convergências}

Conforme abordado no capítulo 1, a consolidação do Mercosul constituiu uma prioridade nos governos de Fernando Henrique Cardoso (1995-2002) e de Lula (20032010). No âmbito da integração regional, ao lado das negociações comerciais e do estabelecimento de regras comuns aos membros da união aduaneira, um dos temas da maior relevância refere-se à circulação de pessoas no espaço do bloco. Nos termos do artigo 1o do Tratado de Assunção, de 1991, a formação do mercado comum implica "a livre circulação de bens, serviços e fatores produtivos entre os quatro Estados Partes". Além de Argentina, Brasil, Paraguai e Uruguai, também se associaram ao Mercosul a Bolívia e o Chile. $^{26}$

Em 2002, esses países firmaram o Acordo de Residência para Nacionais dos Estados Partes do Mercosul, baseado no entendimento de que o aprofundamento do

\footnotetext{
${ }^{26}$ A Venezuela aderiu ao bloco em 2012.
} 
processo de integração exige a implementação de uma política de livre circulação de pessoas. Além da regularização migratória dos nacionais de um país que vivem nos demais países do bloco, os membros reconheceram a importância de combater o tráfico de pessoas para fins de exploração de mão-de-obra.

Pelo artigo 5o do Acordo, os nacionais de uma das partes que desejem estabelecer-se no território de outra parte, podem obter, junto às autoridades competentes do Estado-Parte receptor, a comprovação da nacionalidade e apresentação de certidão negativa de antecedentes judiciais, penais ou policiais no país de origem ou em que houverem residido nos cinco anos anteriores ao pedido de residência. De posse desses documentos, o estrangeiro poderá solicitar a residência permanente durante o período de noventa dias que antecedem o fim do prazo da residência temporária.

Embora o Acordo sobre residência tenha sido assinado no governo FHC, por ocasião da XXIII Reunião do Conselho do Mercado Comum, realizada em Brasília, nos dias 5 e 6 de dezembro de 2002, houve um longo processo de tramitação até sua entrada em vigor. $\mathrm{O}$ instrumento foi ratificado pelo governo Lula em 2005 e passou a vigorar para o Brasil, no plano externo, em 28 de julho de 2009, sendo promulgado pelos Decretos no 6.964, de 29 de setembro de 2009, referente aos quatro membros plenos (Argentina, Brasil, Paraguai e Uruguai), e n- 6.975, de 7 de outubro de 2009, relativo aos Estados associados (Bolívia e Chile), quando passou a integrar o ordenamento jurídico brasileiro.

Pelo Acordo, a condição de residente temporário confere aos nacionais dos Estados-Partes os mesmos direitos e liberdades civis, sociais, culturais e econômicos atribuídos aos nacionais do país de recepção, exceto o que for expressamente vedado pela Constituição daquele país. No caso brasileiro, o direito de votar é vedado aos estrangeiros (art. 14, § 2o da CF/1988).

Não obstante esse impedimento de ordem constitucional, a entrada em vigor do Acordo representa um avanço, pois concede aos imigrantes do bloco o direito de entrar, permanecer, transitar e sair do território das Partes, trabalhar, peticionar às autoridades, associar-se para fins lícitos e professar livremente seus cultos, conforme as leis que regulamentam seu exercício. Outro aspecto importante refere-se à reunião familiar (aos membros da família que não tenham a nacionalidade de um dos Estados Partes, será concedida uma autorização de residência de idêntica vigência à da pessoa da qual dependam), tratamento não menos favorável do que recebem os nacionais do país de recepção (aplicação da legislação trabalhista, especialmente em matéria de 
remuneração, condições de trabalho e seguro social) e acesso à educação para os filhos de imigrantes em condições de igualdade com os nacionais do país de recepção (o acesso às instituições de ensino pré-escolar ou às escolas públicas não poderá ser negado ou sofrer limitações caso a permanência dos pais esteja irregular).

Ainda como parte integrante do esforço de integração sul-americana empreendido durante o governo Lula, o tema da imigração não passou despercebido aos formuladores de política externa dos países envolvidos na conformação da União de Nações Sul-Americanas (UNASUL), que fizeram constar de seu Tratado Constitutivo ${ }^{27}$ a cooperação em matéria migratória e a proteção aos direitos humanos.
A União de Nações Sul-Americanas tem como objetivos específicos:
a) o fortalecimento do diálogo político entre os Estados Membros que assegure um espaço de concertação para reforçar a integração sul-americana e a participação da UNASUL no cenário internacional;
b) o desenvolvimento social e humano com equidade e inclusão para erradicar a pobreza e superar as desigualdades na região; (...)
i) a consolidação de uma identidade sul-americana através do reconhecimento progressivo de direitos a nacionais de um Estado Membro residentes em qualquer outro Estado Membro, com o objetivo de alcançar uma cidadania sul-americana;
j) o acesso universal à seguridade social e aos serviços de saúde;
k) a cooperação em matéria de migração, com enfoque integral e baseada no respeito irrestrito aos direitos humanos e trabalhistas para a regularização migratória e a harmonização de políticas; (...)

Nesse sentido, pode-se afirmar que, para o Brasil, a migração irregular é uma questão humanitária, e não pode ser confundida com a criminalidade. Segundo o discurso oficial, em consonância com seu histórico, o Brasil adota, sobre essa questão, "uma abordagem abrangente e equilibrada, levando em consideração os princípios da universalidade, interdependência e indivisibilidade dos direitos humanos" (LULA DA SILVA, 2009). No dizer de Patarra (2006),

[é] imprescindível que se considerem, hoje, o contexto de lutas e os compromissos internacionais assumidos em prol da ampliação e da efetivação dos direitos humanos dos migrantes, mas é também necessário que se discutam quais os grupos sociais contemplados nas políticas oficiais ancoradas em direitos humanos; é preciso reconhecer, nesse contexto, que os movimentos migratórios internacionais representam a contradição entre os interesses de grupos dominantes na globalização e os Estados nacionais, com a tradicional óptica de sua soberania; há que tomar em conta as tensões entre os níveis de ação internacional, nacional e local. Enfim, há que considerar que os movimentos migratórios internacionais constituem a contrapartida da reestruturação territorial planetária intrinsecamente relacionada à reestruturação econômico-produtiva em escala global.

\footnotetext{
${ }^{27}$ O Tratado Constitutivo da UNASUL, firmado em Brasília em 23 de maio de 2008 e ratificado em 2011, entrou em vigor para o Brasil, no plano externo, em agosto de 2011. O Decreto no 7.667, de 11 de janeiro de 2012, promulgou o Tratado, que a partir de então passou a ter validade no ordenamento jurídico interno.
} 
Com relação à emigração, o Ministério das Relações Exteriores passou a dedicar maior atenção à proteção aos brasileiros no exterior a partir do Governo FHC.

Em seu discurso de posse como Ministro das Relações Exteriores, o Embaixador Luiz Felipe Lampreia elencou alguns pontos de ação para a política externa para os quais o presidente da República determinara especial atenção, "temas que adquirem sentido de premência e de particular importância em seu projeto de Governo, sem que essa necessária priorização signifique qualquer diminuição da importância relativa de outras áreas que compõem o conjunto de uma política externa que se quer universal e pró-ativa" (BRASIL, 1995, p. 24-25). Ao lado do processo de consolidação do Mercosul e sua eventual ampliação com a incorporação de novos parceiros, das relações com os vizinhos latino-americanos e o processo de integração hemisférica, especialmente a partir do aprofundamento das relações com a América do Sul, foi especialmente indicada como prioridade a proteção e a assistência aos brasileiros no exterior.

A primeira medida de importância no plano institucional para os emigrantes se deu em 1995, quando o MRE implementou o Programa de Apoio aos Brasileiros no Exterior, que consistia basicamente na criação dos chamados "consulados itinerantes" para atender a regiões nas quais a presença brasileira vinha crescendo (REIS, 2011, p. 50). Em 1996, outra mudança significativa na legislação reconhecia a importância da emigração brasileira e a necessidade de garantir aos brasileiros estabelecidos em outros países a manutenção dos seus laços com o Brasil e dos seus direitos como cidadãos.

Desde os anos 1990, os brasileiros espalhados pelo mundo têm se organizado para reivindicar seus direitos e políticas de apoio por parte do Estado brasileiro. ${ }^{28} \mathrm{O}$ marco inicial do processo de organização política das comunidades brasileiras no exterior foi o I Simpósio Internacional sobre Emigração Brasileira em 1997. O encontro foi realizado e organizado pela Casa do Brasil em Lisboa, uma das organizações de brasileiros do exterior mais ativas e antigas, e contou com a participação de representantes dos poderes executivos e legislativos do Brasil e de Portugal, pesquisadores e especialistas brasileiros em migrações, jornais e associações de imigrantes, bem como emigrantes isolados pertencentes a outros grupos do Japão e Estados Unidos (ALVES, 2012, p. 67).

\footnotetext{
${ }^{28}$ De acordo com dados compilados pelo MRE, em 2009 existiam 356 associações e organizações de brasileiros em 45 países, além de 216 veículos de mídia a eles dirigidos.
} 
A partir da percepção da inversão dos fluxos tradicionais de imigração e o aumento do número de cidadãos brasileiros vivendo no exterior, o governo brasileiro passou a dedicar maior atenção a essa população, por três razões principais: i) o interesse na manutenção dos vínculos dos emigrantes com o Brasil, em função do aspecto da nacionalidade; ii) o reconhecimento da importância das remessas a partir do exterior para a economia local; iii) a preocupação com a imagem do País no exterior e sua importante repercussão para os interesse nacionais.

Naquela época, o governo estimava em 2 milhões o número de brasileiros que viviam fora do País, sobretudo nos Estados Unidos, América do Sul, Japão e países da Europa Ocidental (Portugal, Espanha, Reino Unido, Alemanha, França e Itália). Houve o reconhecimento de que a saída desses nacionais frequentemente era devida à busca de oportunidades de emprego e melhoria de condições de vida em um cenário de crise econômica. Esse deslocamento, porém, não deveria corresponder a um "afastamento" definitivo desses nacionais. Segundo o então Secretário-Geral do Ministério das Relações Exteriores, as manifestações constantemente recebidas pela rede consular e o volume de recursos anualmente remetidos por brasileiros no exterior - estimados em aproximadamente 3 bilhões de dólares anuais - comprovariam a permanência de profundos vínculos com a pátria e do desejo de retornar (BARROS, 1998, p. 25). O diplomata, em artigo publicado na Revista Brasileira de Política Internacional, em 1998, chamava atenção para o fato de que a atuação do consulado "representa (...) um fator de preservação da cidadania, cujas exigências formais, no tocante ao cumprimento de obrigações referentes ao serviço militar, justiça eleitoral e receita federal, são atendidas por intermédio da repartição consular", o que traduziria, assim, "o interesse do Estado por seus nacionais e sua determinação de protegê-los" (1998, p. 25).

Em termos econômicos, o governo brasileiro tomou consciência da importância das remessas dos emigrados para as economias locais. Conforme o estudo "Perfil Migratório do Brasil 2009”, realizado pela OIM, o Brasil é o segundo maior receptor de remessas da América latina, atrás somente do México, com valores que ultrapassam 5 bilhões de dólares anuais (OIM, 2010, p. 10).

As estatísticas disponíveis, elaboradas pelo Banco Mundial, informam que os Estados Unidos e o Japão seguem entre as mais importantes origens de remessas. 
Gráfico 7. Remessas para o Brasil de 1995 a 2012 (fontes oficiais) - em US\$ milhões

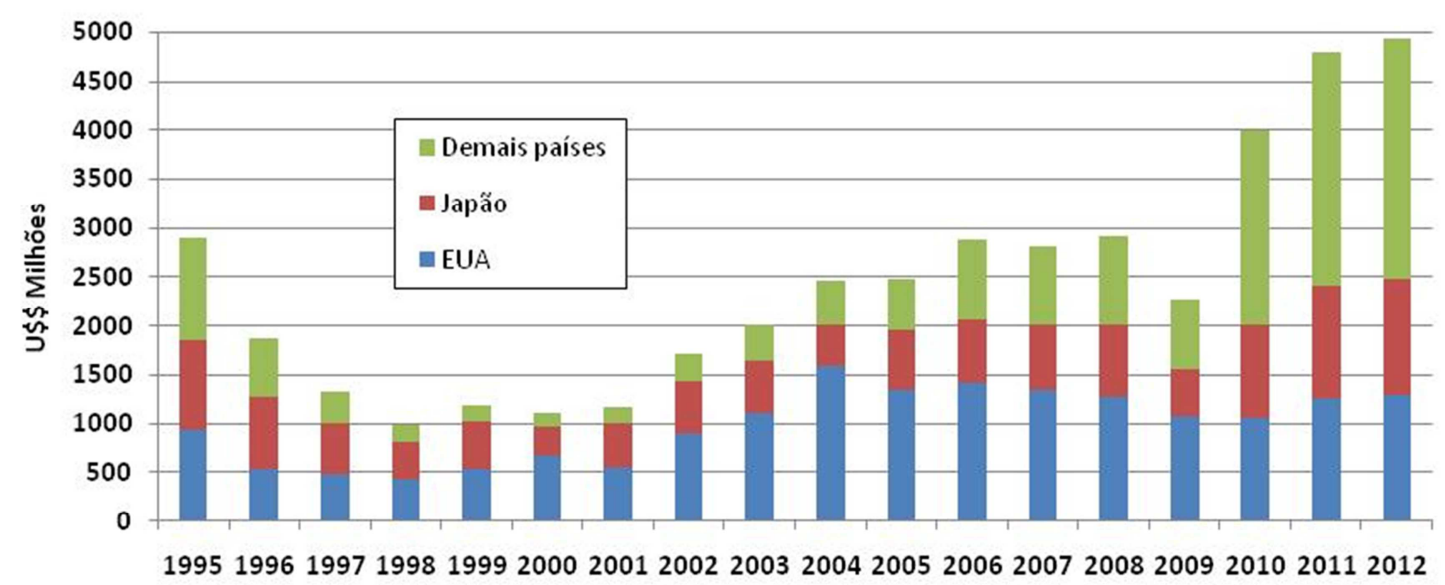

Fonte: OIM 2010 (dados de 1995 a 2009) e Banco Mundial (dados de 2010 a 2012).

Os dados de 2010 a 2012 permitem observar a participação expressiva das remessas a partir da Espanha, Portugal, Paraguai, Reino Unido, Itália, Alemanha, Argentina e França.

Tabela 6. Remessas para o Brasil de 2010 a 2012 (fontes oficiais) - em US\$ milhões

\begin{tabular}{|c|c|c|c|}
\hline & 2010 & 2011 & 2012 \\
\hline Estados Unidos & 1.058 & 1.269 & 1.306 \\
\hline Japão & 948 & 1.134 & 1.168 \\
\hline Espanha & 471 & 563 & 508 \\
\hline Portugal & 197 & 236 & 243 \\
\hline Paraguai & 192 & 231 & 238 \\
\hline Reino Unido & 170 & 203 & 209 \\
\hline Itália & 144 & 172 & 177 \\
\hline Alemanha & 114 & 138 & 142 \\
\hline Argentina & 87 & 105 & 108 \\
\hline França & 84 & 101 & 104 \\
\hline Outros & 535 & 641 & 733 \\
\hline Total & 4.000 & 4.793 & 4.936 \\
\hline
\end{tabular}

Fonte: Banco Mundial.

Os números divulgados pelo Banco Mundial têm como base os dados do Banco Central do Brasil. Entretanto, as estatísticas do Banco Interamericano de Desenvolvimento (BID) apresentam valores muito superiores, significando que grande parte das remessas é transmitida através de meios informais. Essa situação se deve às altas taxas cobradas pelo Banco Central, de $8,9 \%$ a até $20 \%$ das remessas, e a falta de acesso a agências bancárias brasileiras, com exceção do Japão e das grandes metrópoles (ALVES, 2012, p. 54). 
Gráfico 8. Volume de remessas recebidas no Brasil de 2001 a 2007 (estimativas) - em US\$ milhões

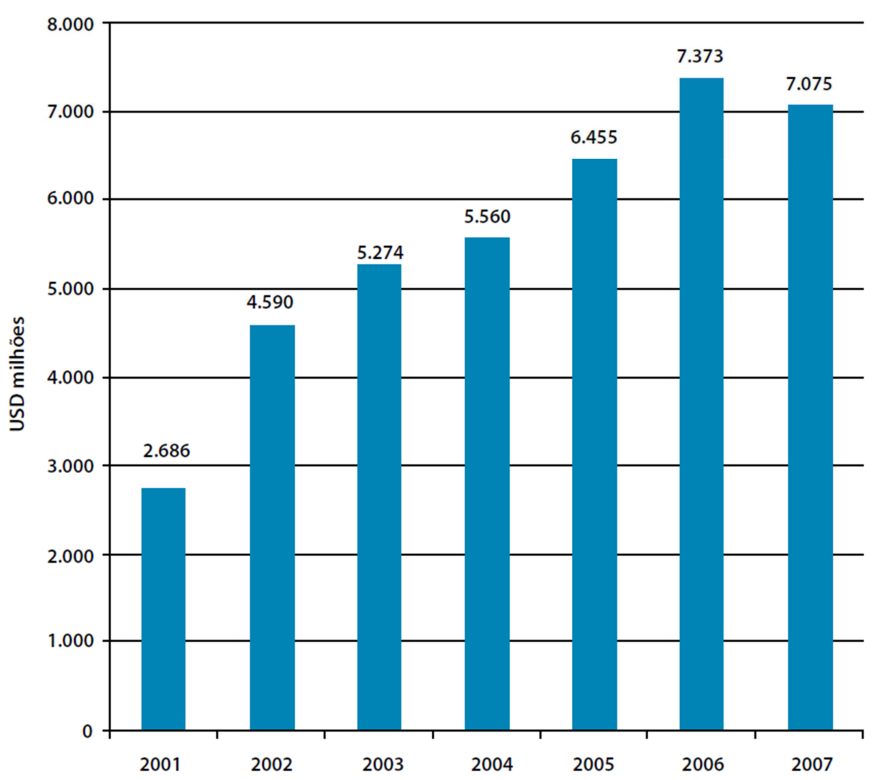

Fonte: OIM (2010, p. 50) com base em FUMIN/BID e Schweizer (2009).

O reconhecimento da importância das remessas dos brasileiros no exterior foi sem dúvida um fator que contribuiu para tornar o Estado brasileiro mais sensível às demandas desses grupos e mais interessado na manutenção dos laços que unem os emigrantes ao Brasil (REIS, 2011, p. 51).

A imagem do Brasil no exterior também constituiu foco de atenção para o governo no relacionamento com seus nacionais emigrados. Essa preocupação está evidenciada em manifestação oficial do então Secretário-Geral do MRE, Sebastião do Rego Barros.

\begin{abstract}
$\mathrm{O}$ atento acompanhamento dos problemas enfrentados pelas comunidades brasileiras no estrangeiro e a pronta e eficiente assistência aos nacionais são importantes fatores da preservação da imagem positiva do País no exterior. E quando menciono a importância da imagem internacional do Brasil não estou me referindo apenas ao tema da credibilidade do Governo no exercício de suas relações exteriores, mas também e principalmente à maneira como são vistos, aceitos e recebidos os brasileiros nos demais países. Os brasileiros serão tanto melhor tratados quanto menos a imagem do País for passível de associação com atividades eventualmente desempenhadas por cidadãos brasileiros em violação às legislações locais e internacionais. O que está em jogo nessas situações é, ao mesmo tempo, a credibilidade do País e a respeitabilidade de seus cidadãos, dois conceitos que, numa sociedade democrática, se complementam (BRASIL, 1997, p. 95). (grifo nosso)
\end{abstract}

Entre as principais iniciativas empreendidas pelo Ministério das Relações Exteriores nesse momento destacam-se: a criação dos Conselhos de Cidadãos junto aos 
consulados e embaixadas, como foros de discussão que reúnem autoridades consulares e representantes das comunidades de brasileiros no exterior; ampliação da rede consular e instituição do sistema de consulados itinerantes, que levam serviços e apoio a nacionais com dificuldades para se deslocar até a repartição consular mais próxima; assistência a presos brasileiros no exterior; prestação de assistência jurídica em determinadas situações; edição de cartilhas consulares; criação da Direção-Geral de Assuntos Consulares, Jurídicos e de Assistência a Brasileiros no Exterior (DCJ); criação do Núcleo de Assistência a Brasileiros na Divisão de Assistência Consular (DAC).

Além disso, o governo procurou tratar algumas questões que tiveram repercussão sobre as relações do Brasil com outros países, buscando evitar que dificuldades de natureza consular degenerassem em constrangimentos e atritos políticos. Como exemplo, pode-se citar a situação dos "brasiguaios" 29 no Paraguai e a dos dentistas brasileiros ${ }^{30}$ em Portugal.

Em 2005, o Congresso Nacional instaurou uma Comissão Mista Parlamentar de Inquérito (CPMI) ${ }^{31}$ para "apurar os crimes e outros delitos penais e civis praticados com a emigração ilegal de brasileiros para os Estados Unidos e outros países, e assegurar os direitos de cidadania aos brasileiros que vivem no exterior" (BRASIL, 2006).

A partir das recomendações da CPMI, o MRE criou, em 2006, a SubsecretariaGeral das Comunidades Brasileiras no Exterior (SGEB), para "cuidar dos temas relativos aos brasileiros no exterior e aos estrangeiros que desejam ingressar no Brasil, incluindo-se a cooperação judiciária internacional" (AMORIM, 2009 apud REIS, 2011, p. 53).

Em paralelo, outras ações importantes foram realizadas pelo governo, como a assinatura de acordos bilaterais na área de previdência social com países como Chile, Japão, Estados Unidos e Alemanha, e as resoluções da Caixa Econômica Federal estabelecendo as condições para que os emigrantes possam retirar o Fundo de Garantia por Tempo de Serviço (FGTS) no Japão ${ }^{32}$ (REIS, 2011).

\footnotetext{
${ }^{29}$ Em virtude da insatisfação dos paraguaios com a presença de comunidade brasileira, estimada em 350 mil pessoas (dados de 2012) em cidades próximas à fronteira, têm sido registradas invasões de propriedades de brasileiros por trabalhadores sem-terra do Paraguai e pressões para que o governo paraguaio desaproprie terras na região em favor desse movimento (GLOBO, 2012a).

${ }_{30}$ Questão envolvendo dentistas brasileiros e portugueses por conta de divergências quanto ao reconhecimento de diplomas e autorização de trabalho de dentistas brasileiros em Portugal.

${ }^{31}$ A "CPMI da Emigração Ilegal", como ficou conhecida, buscou investigar as redes de tráfico de pessoas. O relatório final da CPMI foi aprovado em 12 de julho de 2006.

32 Atualmente, os brasileiros residentes em países como Estados Unidos, Japão, Argentina, Bolívia, Paraguai e alguns países da Europa (Alemanha, Áustria, Bélgica, França, Holanda, Itália, Portugal, Reino Unido e Suíça) podem solicitar autorização de saque junto aos consulados locais.
} 
Em 2010, a política governamental para as comunidades brasileiras no exterior foi institucionalizada pelo Decreto no 7.214 , que estabeleceu princípios e diretrizes ${ }^{33}$ norteadores da atuação do MRE e determinou as seguintes medidas:

"I - reforma consular, a ser implementada mediante Plano Diretor definido pelo Ministro de Estado das Relações Exteriores, para o aprimoramento do atendimento ao público, agilização da prestação de serviços e ampliação da atividade consular, em benefício das comunidades de brasileiros que vivem no exterior;

II - modernização dos recursos tecnológicos, especialmente do Sistema Consular Integrado do Ministério das Relações Exteriores, com o objetivo de melhorar a qualidade e a segurança de documentos de viagem e notariais, bem como ampliar o atendimento consular; e

III - realização de eventos relacionados às comunidades brasileiras no exterior e de conferências periódicas destinadas a incentivar sua interação com o governo e permitir a discussão de projetos em seu benefício."

Para Reis (2011), o tratamento dado à questão migratória pelo Estado brasileiro está relacionado não apenas ao importante ativismo de migrantes e seus aliados, mas também

tem relação direta com o objetivo de defender e assegurar o protagonismo do país em fóruns regionais e multilaterais, dentro de um contexto internacional em que o tema é cada vez mais importante e controverso. Nesse sentido, podemos caracterizar a política em relação aos emigrantes, e também aquelas de cunho regional, como formas de política externa. Nos últimos anos, mesmo a política de imigração começou a ser percebida como parte importante da posição do Brasil em relação às migrações no plano internacional, o que explica as mudanças que estão sendo propostas no sentido de tornar mais coerente a posição do país em relação às migrações no sentido mais amplo (REIS, 2011, p. 49).

\footnotetext{
33 "Art. 1o A política governamental para as comunidades brasileiras no exterior nortear-se-á pelos seguintes princípios e diretrizes: I - pleno direito de locomoção dos brasileiros, respeitadas as normas legais e regulamentares cabíveis; II - adequada informação sobre requisitos de entrada e permanência em outros países; III - aumento da interação entre o Ministério das Relações Exteriores e os brasileiros que vivem fora do Brasil; IV - promoção do autodesenvolvimento e de melhores condições de vida aos brasileiros que vivem no exterior, inclusive mediante a prestação de serviços consulares de segunda geração, como nas áreas de educação, saúde, trabalho, previdência social e cultura; V - incentivo a pesquisas que permitam o mapeamento das comunidades brasileiras no exterior e subsidiem a formulação de políticas públicas nessa área; VI - defesa e apoio das comunidades brasileiras no exterior, e valorização e aprofundamento do conhecimento sobre o seu perfil, de forma a destacar sua colaboração para os países receptores; VII - incentivo à inserção harmoniosa da comunidade brasileira na sociedade local, sem prejuízo da preservação da identidade brasileira e dos vínculos com o Brasil; VIII - realização de parcerias para aproveitamento do potencial dos brasileiros no exterior, com destaque para comunidades específicas, tais como científica, cultural, jurídica, política e esportiva, com o objetivo de promover o Brasil, sua cultura e seus produtos; IX - atuação diplomática, nos âmbitos bilateral, regional e multilateral, em defesa dos legítimos direitos dos emigrados e viajantes brasileiros, com base no direito internacional; $\mathrm{X}$ - articulação da política para as comunidades brasileiras no exterior com as políticas emigratórias e imigratórias que venham a ser desenvolvidas pelo governo brasileiro; e XI - ação governamental integrada, sob coordenação do Ministério das Relações Exteriores, com a participação de órgãos do governo com atribuições nas áreas temáticas mencionadas nos incisos anteriores, com vistas a assistir as comunidades brasileiras no exterior."
} 
Outro aspecto bastante simbólico do interesse do governo brasileiro de envolver o tema das migrações internacionais na política externa pode ser observado a partir da iniciativa de ingressar na Organização Internacional para as Migrações (OIM). ${ }^{34}$ Tendo até então participado das reuniões na qualidade de observador, o Brasil manifestou a intenção de integrar a OIM em 2004. ${ }^{35}$

\begin{abstract}
A iniciativa do Governo brasileiro é fruto de ação conjunta dos Ministérios das Relações Exteriores, da Justiça e do Trabalho e Emprego, bem como do Conselho Nacional de Imigração. Reflete a crescente importância do fenômeno migratório no mundo e, em especial, a atenção dispensada pelo Brasil a seus nacionais residentes no exterior. A participação do Brasil na OIM permitirá aprimorar a assistência aos cidadãos brasileiros em todas as partes do mundo, bem como a elaboração de políticas públicas relacionadas com a migração e a imigração (BRASIL, 2004, p. 457).
\end{abstract}

Em discurso no Conselho de Direitos Humanos da ONU, em 15 de junho de 2009, o Presidente Lula abordou a crise financeira internacional e seus efeitos sobre os países pobres.

\begin{abstract}
Essa crise teve um efeito perverso sobretudo quando os imigrantes sobretudo os pobres africanos, latino-americanos, asiáticos - que transitam pelo mundo à procura de oportunidade de trabalho, começam a ser enxergados como responsáveis por ocupar um lugar das pessoas filhas dos países. Como disse em meu documento, no Brasil, nós acabamos de legalizar centenas de milhares de imigrantes que viviam ilegalmente no país para dar uma resposta, para dar um sinal aos preconceituosos, àqueles que imediatamente querem encontrar os responsáveis pela sua própria desgraça, pelo seu desemprego. E não são os imigrantes os responsáveis pela crise, não são os pobres do mundo [os] responsáveis pela crise. Os responsáveis pela crise são os mesmos que durante séculos sabiam como administrar os Estados. Sabiam ter ingerência nos Estados pobres da América Latina e da África. E esses mesmos senhores, que sabiam de tudo há algum tempo, hoje não sabem mais nada. Não conseguem explicar como davam tantos palpites sobre as políticas dos países pobres e que não têm sequer uma palavra para a analisar a crise dos países ricos (LULA DA SILVA, 2009a, p. 181).
\end{abstract}

\title{
Como linha de ação da política externa empreendida pelo Governo Lula,
} observou-se um maior empenho brasileiro em aderir a acordos internacionais na esfera

\footnotetext{
${ }^{34}$ A OIM foi fundada em Genebra em 1951 e tem por objetivo promover estudos e ações de cooperação com governos e organizações da sociedade civil sobre temas migratórios e oferecer assistência humanitária aos migrantes.

${ }^{35}$ Apesar de a República Federativa do Brasil ter sido aceita como membro da OIM pela Resolução no 1.105, adotada em 30 de novembro de 2004, o Congresso Nacional publicou o Decreto Legislativo no 302 somente em 24 de outubro de 2011. O Governo brasileiro depositou o instrumento de adesão à OIM junto ao Diretor-Geral daquela organização em 22 de junho de 2012. O Decreto n- 8.101, de 6 de setembro de 2013, promulgou a referida Resolução e a Constituição da OIM, passando, assim, a integrar o ordenamento jurídico brasileiro.
} 
dos direitos humanos dos migrantes. Um dos principais documentos aos quais o Brasil aderiu ainda se encontra pendente de ratificação. Trata-se da Convenção Internacional sobre a Proteção dos Direitos de Todos os Trabalhadores Migrantes e dos Membros das suas Famílias, adotada pela Resolução 45/158 da Assembleia-Geral das Nações Unidas, de 18 de dezembro de 1990.

Em vigor desde 2003, a Convenção reconhece e protege todos os trabalhadores migrantes, inclusive aqueles em situação migratória irregular. Segundo o art. $2^{2}$ da Convenção, "trabalhador migrante é a pessoa que vai exercer, exerce ou exerceu uma atividade remunerada num Estado do qual não é nacional". A Convenção estabelece, ainda, que os trabalhadores migrantes devem beneficiar-se de um tratamento não menos favorável que aquele concedido aos trabalhadores nacionais em matéria de retribuição e condições de trabalho.

Segundo a Exposição de Motivos do Ministro das Relações Exteriores,

\begin{abstract}
O instrumento visa a proteger os direitos de todos os trabalhadores migrantes e membros de suas famílias, independentemente de sua situação migratória. Os migrantes indocumentados constituem parte significativa da totalidade dos migrantes e têm sido sujeitos a diversas violações a seus direitos humanos em países de trânsito e de destino. Suas condições de vida e de trabalho são frequentemente degradantes, devido à fragilidade advinda de seu "status" precário nos países para os quais se dirigem. A proteção de direitos dos chamados migrantes indocumentados visa a evitar esta exclusão social e as violações reiteradas a direitos inerentes à condição de pessoa humana (BRASIL, 2010b).
\end{abstract}

A decisão de assinar a Convenção de 1990 reflete não apenas o reconhecimento do Governo Lula de que a adesão a esse instrumento normativo teria o efeito de ampliar a quantidade de Estados signatários, mas também a preocupação de assegurar ao Brasil uma postura coerente com seu histórico de defesa de direitos humanos em foros internacionais.

\footnotetext{
Em contexto de restrição cada vez maior da entrada, permanência e garantia dos direitos dos migrantes, a ratificação da Convenção pelo Brasil representaria fortalecimento de sua posição favorável à defesa da proteção dos direitos humanos, daria maior legitimidade a seu papel em foros internacionais sobre direitos dos migrantes e poderia ser estímulo ao processo de universalização da ratificação deste importante instrumento de direitos humanos (BRASIL, 2010c). (grifo nosso)
}

Ocorre, porém, que o presidente da República enviou o texto da Convenção para apreciação do Congresso Nacional pela Mensagem no 696, de 13 de dezembro de 2010, e, desde então, está pendente uma decisão sobre a ratificação do documento. Em 2011, a Presidência da Câmara dos Deputados criou uma Comissão Especial destinada a 
proferir parecer sobre o texto. Segundo informações fornecidas pelos entrevistados para esta pesquisa, o processo encontra-se em consulta aos Ministérios, sem previsão de quando será concluído. O Brasil é o único país do Mercosul que ainda não ratificou o documento (BARALDI, 2011).

A resistência de algumas instâncias governamentais e da própria sociedade brasileira em discutir a possibilidade de ratificação da Convenção aponta para uma falta de sintonia entre as posições assumidas pelo Brasil na esfera internacional e as políticas efetivamente implementadas para as migrações em âmbito interno.

Algo similar ocorre em relação às anistias, que são menos resultado de posicionamento em política externa, mas obedecem a uma dinâmica própria. Segundo Milesi (2009), se, por um lado, os Estados buscam sustentar suas posições de controlar o movimento imigratório, por outro, a realidade migratória, a necessidade de mão-deobra, a pressão da sociedade, os movimentos organizados e as entidades de apoio ao migrante provocam os Governos a efetuarem regularizações, sob diferentes formas ou alternativas, a favor desta população.

As leis de regularização migratória (leis de anistia) dos estrangeiros em situação irregular de 1998 e 2009 podem ser apontadas como uma evolução em relação às anteriores, de 1981 e 1988.

A primeira anistia foi realizada pela Lei no 6.964, de 9 de dezembro de 1981 . Permitia a regularização do estrangeiro em situação irregular que tivesse ingressado em território nacional até 20 de agosto de 1980. A regularização tinha caráter temporário, por até dois anos improrrogáveis, e permitia ao imigrante trabalhar e obter identidade junto às autoridades nacionais. Após esse período, caso houvesse acordo bilateral com o Brasil e o Estado de nacionalidade do imigrante, poderia ser autorizada a regularização em caráter permanente. Segundo Milesi (2009), a situação jurídica introduzida pela lei não representou uma "anistia" de fato, pois "houve confusão nas informações sobre tal registro provisório e muitos estrangeiros em situação irregular no Brasil que se apresentaram à Polícia Federal pedindo o registro foram autuados com pena de multa e notificados a deixarem o país". Diversos problemas, como o excesso de burocracia, a falta de divulgação e de esclarecimentos sobre os procedimentos e a seleção rigorosa empregada pelos agentes da Polícia Federal, fizeram com que a regularização deixasse se atingir um contingente expressivo de estrangeiros que se encontravam indocumentados no Brasil, sendo anistiadas apenas 27.000 pessoas (MILESI, 2009). Milesi relata, ainda, que as pressões sociais levaram à edição da Lei no - 7.180, de 20 de 
dezembro de 1983, que dispunha sobre a concessão da permanência no Brasil aos estrangeiros registrados provisoriamente.

No Governo Sarney, a segunda anistia (Lei no 7.685, de 1988), permitiu a regularização dos estrangeiros que tivessem ingressado no território nacional até o dia 2 de dezembro de 1988, data da promulgação. Previa a regularização por dois anos, prorrogáveis por igual período, mediante solicitação do interessado e desde que realizada até 90 dias antes do vencimento do prazo original. Foi permitida a conversão do visto temporário em permanente, desde que atendidas as exigências legais. $\mathrm{O}$ portador do registro provisório ficava autorizado a exercer atividade remunerada, a realizar matrícula em instituição de ensino e a gozar de livre locomoção pelo território nacional, em condição análoga ao detentor de visto temporário (SICILIANO, 2013, p. 44). Milesi (2009) registra que "as estimativas sobre a presença de estrangeiros em situação irregular no país sempre foram muito desencontradas, sem dados", sendo impossível "estabelecer qualquer relação com o total de estrangeiros em situação irregular no país". Segundo estimativas da autora, por esta Lei, 36.990 pessoas obtiveram o documento provisório (MILESI, 2009).

A terceira anistia foi concedida no Governo FHC, com a aprovação da Lei no 9.675, de 1998, a qual foi regulamentada pelo Decreto no 2.771 , de 7 de setembro de 1998. Esta lei ampliou, para o estrangeiro indocumentado residente no território nacional, o prazo para requerer o registro provisório, aplicando-se as mesmas disposições da lei anterior para os estrangeiros que tivessem ingressado no território nacional até 30 de junho de 1998 (SICILIANO, 2013, p. 44).

A anistia mais recente foi concedida no Governo Lula, por meio da Lei no11.961, de 2009, que permitiu ao estrangeiro em situação imigratória irregular no território nacional até 1 o de fevereiro de 2009, requerer o visto temporário por até 2 anos. Conforme a referida Lei, o estrangeiro poderia requerer a transformação da autorização temporária em permanente até 90 dias antes do fim do período, condicionado a: i) comprovação do exercício de profissão ou emprego lícito; ii) inexistência de débitos fiscais e de antecedentes criminais; e iii) não ter se ausentado do país por prazo superior a 90 dias consecutivos.

Por ocasião da sanção da Lei, em 2 de julho de 2009, o presidente Lula reconheceu que a medida resultara de "um amplo debate nacional, com a participação de diferentes setores da sociedade e dos próprios imigrantes, que tiveram, assim, a oportunidade de esclarecer os problemas que enfrentam e propor soluções." Para Lula, a 
nova legislação significava "que o Brasil se coloca cada vez mais à altura da realidade migratória contemporânea, das condições globais do desenvolvimento econômico e social, e do respeito fundamental aos direitos humanos" (LULA DA SILVA, 2009b).

No discurso oficial, a anistia é relacionada ao aprofundamento e à ampliação do processo de integração da América do Sul e também à intensificação das correntes migratórias de nossos irmãos da América do Sul e da América Latina. Além disso, o então presidente da República registra, acertadamente, que

\footnotetext{
[n]ão podemos esquecer que a própria Constituição brasileira, quando trata dos direitos e garantias fundamentais, estabelece que todos são iguais perante a lei, sejam brasileiros ou estrangeiros residentes. O Estado brasileiro, por meio de compromissos firmados em vários acordos internacionais, reconhece que os migrantes são titulares de direitos e deveres que devem ser respeitados (LULA DA SILVA, 2009b).
}

De acordo com Milesi (2009), referindo-se ainda à Lei de 1998, a anistia é antiga aspiração dos organismos sociais que trabalham pelos Direitos Humanos e especificamente em prol dos imigrantes indocumentados. Estes são hoje em número significativo, principalmente os latino-americanos, sob a permanente ameaça de deportação, ainda que tenham vivido aqui mais tempo do que em seu próprio lugar de origem. A autora chama atenção, ainda, para o fato de que, por sua situação de indocumentados, "os estrangeiros são muitas vezes submetidos a um regime de exploração laboral, vivem com medo, evitam integrar-se na sociedade, ou acabam sendo envolvidos em negócios ilícitos, muitas vezes pressionados por exploradores ou por redes criminosas de tráfico" (MILESI, 2009).

\subsection{Focos de resistência}

Conforme visto anteriormente, o governo brasileiro manteve, entre os anos de 1995 e 2010, uma postura de defesa dos direitos humanos dos migrantes nos foros internacionais. O Brasil se apresentou como país de oportunidades e aberto à imigração. Da mesma forma, abriu-se um canal de comunicação mais estreita com os nacionais no exterior, e a proteção e defesa dos interesses dos brasileiros emigrados passou também a ser uma das linhas de ação prioritárias nos discursos oficiais.

Entretanto, como ocorre com muitas políticas públicas, a realidade não condiz com a retórica. Enquanto o Estatuto dos Estrangeiros não passa por uma atualização mais consistente, que promova uma maior observância aos direitos humanos, a política 
migratória vem sendo balizada pelas Resoluções Normativas do Conselho Nacional de Imigração, entidade vinculada ao Ministério do Trabalho e Emprego, que conta com representação quadripartite (governo, entidades sindicais, empresários e comunidade científica e tecnológica).

As entrevistas conduzidas com representantes de órgãos governamentais envolvidos com a questão migratória revelaram visões bastante diferentes por parte desses órgãos quanto à temática, sendo que no Ministério da Justiça, é nítida a diferença de posicionamentos entre a Secretaria Nacional de Justiça (SNJ) e o Departamento de Polícia Federal (DPF).

A partir de entrevista realizada com o Diretor do Departamento de Estrangeiros (DEEST), vinculado à SNJ, foi possível perceber uma visão mais prospectiva, de marcado enfoque na necessidade de reconhecimento dos direitos dos migrantes, da sua inserção e integração, da preservação de sua dignidade enquanto seres humanos e sujeito de direitos. Repercutindo os apelos da comunidade acadêmica e das entidades de assistência aos migrantes, o DEEST reconhece a necessidade de superação da legislação herdada do Regime Militar, e advoga pela substituição do Estatuto do Estrangeiro por leis e regulamentos mais condizentes com o espírito democrático consagrado na Constituição Federal de 1988. O DEEST defende, ainda, uma discussão mais ampla sobre alguns temas polêmicos, como a extensão do direito de voto aos estrangeiros residentes em eleições municipais. O tema é objeto das Propostas de Emenda Constitucional no 119, de 2011, e no 347, de 2013. Apesar de esse direito ser garantido a estrangeiros residentes em outros países sul-americanos, como Argentina (após 2 anos de residência permanente), Chile (5 anos), Paraguai (sem mínimo de tempo) e Uruguai (15 anos), ainda não há consenso na sociedade brasileira sobre a adequação da proposta e o tempo mínimo de residência que poderia habilitar os estrangeiros residentes a votar.

O Departamento de Polícia Federal, órgão integrante da estrutura do Ministério da Justiça, tem uma visão mais pautada em segurança. A entrevista com o CoordenadorGeral de Polícia de Imigração foi bastante esclarecedora a respeito da posição da Polícia Federal sobe a imigração. Embora haja o reconhecimento de que o arcabouço jurídico vigente se apresente ultrapassado, a função do DPF é garantir a segurança das fronteiras e atuar em conformidade com as competências atribuídas ao órgão pela Constituição Federal. Assim, não caberia ao DPF propor a alteração das normas referentes à entrada e permanência de estrangeiros no Brasil, mas sim ater-se à sua responsabilidade na aplicação da lei. A discussão sobre as alterações consideradas necessárias para garantir 
os direitos dos migrantes - e também suas obrigações - deve ser objeto de debate pela sociedade e deliberação pelos parlamentares. Nesse sentido, caberia ao Congresso Nacional introduzir mudanças no ordenamento jurídico, a fỉm de torná-lo consentâneo não apenas com os anseios das populações migrantes e das entidades que atuam em sua defesa, mas também no âmbito dos compromissos assumidos pelo Brasil no âmbito do Mercosul e da Unasul. Quanto ao Mercosul, desde 1997, são realizadas reuniões anuais do Foro Especializado Migratório do Mercosul e Estados Associados, integrado pelos Ministros do Interior e da Justiça dos respectivos membros do bloco, no qual são discutidas iniciativas para a harmonização da legislação migratória na região. Entre os diversos temas tratados, incluem-se controles migratórios e proteção aos direitos humanos de migrantes e refugiados. No âmbito da UNASUL, são realizadas, desde 2000, as Conferências Sul-Americanas sobre Migrações, da qual participam representantes dos órgãos envolvidos no tema. Há, portanto, interlocução do Ministério da Justiça com seus congêneres em âmbito regional, o que contribui para a atualização do órgão quanto aos debates contemporâneos sobre a proteção dos direitos humanos dos migrantes nos países sul-americanos.

Com relação ao Ministério das Relações Exteriores, a postura é de reserva quanto propostas que promovam alterações muito abruptas na legislação e uma abertura incondicional do país à imigração. Foi realizada entrevista com o Diretor do Departamento de Imigração e Assuntos Jurídicos (DIJ), em que sobressaiu a preocupação do Itamaraty com os brasileiros no exterior, como reflexo das novas condições em que se encontram e da mobilização que proporcionou visibilidade, conseguindo atrair o interesse do presidente da República. O Diretor do DIJ ressaltou o fato de que, conforme comentado anteriormente, a criação da SGEB, como resultado da CPMI da Emigração Ilegal, a realização das Conferências Brasileiros no Mundo $(\mathrm{CBM})^{36}$ e a criação dos Conselhos de Representantes das Comunidades Brasileiras no Exterior $(\mathrm{CRBE})^{37}$ são iniciativas que resultam da maior visibilidade dos temas relacionados à emigração e da prioridade atribuída pelo governo às questões envolvendo os direitos dos nacionais no exterior. A reciprocidade em relação aos demais países é princípio caro à diplomacia, e a condição dos brasileiros constitui importante instrumento de barganha com os governos estrangeiros. Assegurar condições dignas de

\footnotetext{
${ }^{36}$ A primeira Conferência foi realizada em 2008, no Palácio do Itamaraty do Rio de Janeiro. Até o momento já foram realizadas quatro Conferências (2008, 2009, 2010 e 2013).

${ }^{37}$ Em 2009, na II CBM, foi sugerida a criação dos Conselhos de Representantes Brasileiros no Exterior (CRBE), posteriormente institucionalizados pelos Decretos no 7.214, de 2010, e no 7.987, de 2013.
} 
tratamento nos aeroportos e tratamento adequado durante a estada ou permanência é, na visão do MRE, o objetivo de política externa no que se refere aos brasileiros que fixam residência no exterior. Sendo assim, o Itamaraty desenvolveu uma visão bastante pragmática do tema, mas que não impede uma participação construtiva nas ações de política migratória. Entretanto, com base na entrevista realizada, foi possível concluir que a atuação do MRE ainda é limitada, em grande parte devido a fortes restrições orçamentárias, e pouco orientada pela percepção do potencial positivo representado pelos fluxos migratórios para o processo de desenvolvimento nacional.

Para o Itamaraty, a questão da reciprocidade é crucial no debate sobre as políticas migratórias. Em audiência pública na Comissão de Relações Exteriores da Câmara dos Deputados, o então Subsecretário-Geral das Comunidades Brasileiras no Exterior, Embaixador Sergio Danese ${ }^{38}$, destacou que o Brasil deve ter uma lei de imigração "que possa permitir da melhor maneira possível o rápido exercício ou da reciprocidade ou da retorsão ${ }^{39}$ (...) quando interessar a nós, obviamente, e quando se trata de lidar com a forma como países amigos, vizinhos ou outros Estados estrangeiros tratem os nossos nacionais" (DANESE, 2013). Na opinião do diplomata, o Brasil não pode ser "ingênuo" a ponto de acreditar que o fato de ter uma legislação mais "branda" para os estrangeiros terá como contrapartida um melhor tratamento aos brasileiros no exterior. Isso não seria uma consequência automática da mudança na legislação, e sim, resultado de um processo de negociação entre os Estados.

A questão da reciprocidade nas relações internacionais também é abordada por Lopes (2009), para quem a aplicação do princípio por parte dos países periféricos apresenta algumas desvantagens no que se refere aos temas migratórios.

Toda vez que a legislação disciplinar algo sobre os interesses do Brasil em face dos estrangeiros, estará legitimando que os brasileiros sejam tratados da mesma maneira no exterior. Assim preconiza o princípio da reciprocidade, regra que estabelece esse paralelismo entre o tratamento dado a estrangeiros no país e brasileiros no exterior. Mas o princípio da reciprocidade não é solução fácil para o problema, porque sua aplicação dependeria da existência de alguma homogeneidade (igualdade) entre os países. Basicamente, aplicar o princípio é uma armadilha para os países periféricos, porque os cidadãos de países centrais têm menos interesse em buscar oportunidades de sobrevivência e prosperidade em países periféricos. Ainda que corra o risco de sofrer represálias decorrentes da aplicação do princípio da reciprocidade pelo país periférico, o país central tenderá a defender com prioridade o seu

\footnotetext{
${ }^{38}$ Passou a ocupar o cargo de Secretário-Geral do Ministério das Relações Exteriores em janeiro de 2015.

${ }^{39}$ Enquanto a reciprocidade, em geral, tem um caráter positivo, na forma de retribuição de uma cortesia ou gentileza, a retorsão constitui uma reação negativa, quando tal cortesia deixa de ser estendida ao nacional de um país e quebra-se a igualdade de tratamento. O Estado agravado, então, tende a demonstrar à parte violadora do acordo a sua desaprovação (PORTO, 2009, p. 93).
} 
interesse nacional, mesmo que a ele se contraponha o interesse da humanidade (LOPES, 2009, pp. 27-28).

Para o Embaixador Sergio Danese, então Subsecretário-Geral das Comunidades Brasileiras no Exterior, a lei imigratória

\begin{abstract}
deve responder a interesses concretos do país em matéria de circulação de pessoas, de acolhida dessas pessoas, por exemplo, essa questão da mão-deobra qualificada que foi mencionada aqui, a questão do monitoramento da capacidade de absorção que a economia brasileira, que a sociedade brasileira tem, em relação a esses contingentes de imigrantes que buscam o Brasil, o direito do Estado brasileiro de fazer, sim, algum tipo de seleção, por exemplo, tentando evitar a vinda de pessoas que seriam indesejáveis em função de um passado criminoso ou de um passado de atividade que pudessem representar algum tipo de perigo para a sociedade brasileira (DANESE, 2013).
\end{abstract}

Com base nessa verbalização e a partir das impressões do Diretor do DIJ, parece razoável afirmar que o Itamaraty guarda, em relação aos imigrantes, uma postura intermediária entre aquela manifestada pelo DEEST, de maior abertura e revisão das políticas restritivas de entrada e permanência dos estrangeiros em território nacional, e a do DPF, mais reticente e cautelosa, mas também mais direcionada para o controle e para as questões de segurança.

Quanto ao Ministério do Trabalho e Emprego, a entrevista com o Presidente do Conselho Nacional de Imigração, que também exerce o cargo de Secretário Nacional de Inspeção do Trabalho, permite registrar uma marcante inflexão em favor da aceitação da migração de natureza não laboral, embora a atuação do CNIg ainda esteja muito preocupada com a defesa do trabalhador nacional, algo que está na origem da criação do órgão. Observa-se, a partir da leitura das Atas do CNIg, que Resoluções Normativas como a dos refugiados (n- 06/1997), a que trata de vítima de tráfico de pessoas ( $\mathrm{n}^{\mathrm{o}}$ 93/2010), a relativa à concessão de visto humanitário para haitianos (no 97/2012) e a da reunião familiar (n- 108/2014), entre outras, resultam de uma postura mais aberta do órgão, apesar de ainda haver resistências. Para o presidente do CNIg, em quadro de transição demográfica, é possível inferir que postos de trabalho serão criados e que demandarão mão-de-obra estrangeira. Cabe ao Estado, portanto, estabelecer critérios para a ocupação dessas vagas, sempre que possível, porém sem discriminação e evitando o desenvolvimento de sentimentos xenófobos entre a população.

Além dos ministérios já citados, vale registrar que os órgãos de defesa também vêm dedicando atenção à questão migratória. Em relatório elaborado para o EstadoMaior das Forças Armadas sobre os potenciais desafios à integração e à segurança na 
Panamazônia (a área compreendida pela Amazônia brasileira e os demais Estados que a integram), Rocha Barros (2013) aborda as questões demográficas como de alta relevância nos projetos estratégicos para a região:

\begin{abstract}
O aumento ou a diminuição da população em determinadas áreas da Panamazônia será consequência de oportunidades surgidas nos países condôminos, podendo ser um fator positivo se houver projetos de desenvolvimento que possam absorver os migrantes. O ideal é que haja oportunidades em ambos os lados dos polos e subpolos de integração, a fim de evitar o descontrole da migração. Grandes fluxos migratórios sem perspectiva de assimilação e melhoria de vida poderão colocar em risco a ordem interna nas regiões de destino. Se bem conduzida, a imigração reforça a população economicamente ativa de um país e evita o decréscimo populacional, ameaça prevista para começar em três décadas no Brasil. Por isso, um significativo fluxo de imigrantes será benéfico se bem administrado. Por outro lado, a Amazônia pode ser alvo de pressões internacionais para receber, no futuro, contingentes populacionais indesejados em países da União Europeia ou que estejam em áreas degradadas de outros continentes, onde as condições de sobrevivência sejam precárias (ROCHA BARROS, 2013, p. 21).
\end{abstract}

Da mesma forma, é possível que em alguns anos o Brasil volte a precisar de maiores contingentes de imigrantes para ocupar determinadas posições para as quais já começa a faltar mão-de-obra nacional. Por isso, pode ser recomendável que a sociedade e o governo brasileiros comecem a discutir desde já as mudanças necessárias na política migratória para fazer face a essas novas exigências, tanto em matéria de proteção dos direitos humanos dos migrantes, quanto em relação às questões de segurança.

\title{
3.3. Articulação entre a política externa e a política migratória
}

A partir das análises sobre os pontos de convergência e distanciamento entre as políticas externa e migratória, é possível identificar algumas vantagens e desvantagens da coordenação dessas políticas com potenciais impactos para a imagem do Brasil e o fortalecimento do soft power brasileiro.

O Brasil se apresenta, na esfera internacional, como um país de oportunidades, aberto à imigração, que não pratica as políticas cada vez mais restritivas que vem se tornando comuns no mundo desenvolvido. Nos países da União Europeia e nos Estados Unidos, os imigrantes indocumentados são considerados "ilegais", sujeitos à prisão e à deportação sumária. Além disso, em alguns países, determinados grupos étnicos vem sendo sistematicamente removidos dos territórios nacionais por decreto presidencial, caso dos ciganos romenos e búlgaros na França. 
Embora a prisão e a deportação de estrangeiros sejam medidas autorizadas pela Lei no 6.815 , de 1980, elas não ocorrem de forma massificada como nos países da Europa ou nos Estados Unidos. Além disso, a situação dos estrangeiros com documentação em desacordo com a legislação (ou sem documentação alguma) no Brasil é com cada vez mais frequência denominada "irregular", e não "ilegal". O governo tem manifestado o entendimento de que a imigração irregular não deve ser criminalizada.

As estatísticas apontam que o Brasil é um país ainda muito "fechado à imigração" ${ }^{40}$ : a população estrangeira representa apenas $0,3 \%$ da população total, enquanto a média mundial é de 3\% (OCDE, 2013).

Ademais, o movimento de brasileiros, tanto de emigrantes quanto de brasileiros retornados, principalmente a partir da crise financeira de 2008, que reduziu as oportunidades de emprego nos países desenvolvidos, tem sido maior do que as entradas de estrangeiros. E, por fim, os números mostram que, entre 1995 e 2010, os contingentes de estrangeiros que buscam o Brasil para residir seguem as nacionalidades que já se encontravam no território nacional, isto é, são fluxos tradicionais. ${ }^{41}$ Logo, não se verifica nenhuma mudança significativa em relação ao panorama das migrações no período.

Não obstante, é possível observar que a política externa do Brasil no período influenciou alterações na política migratória, tendo em conta Resoluções Normativas do CNIg, as anistias concedidas aos migrantes em situação irregular, a assistência prestada aos brasileiros no exterior e a legislação sobre refúgio.

Sobre as Resoluções Normativas, já foi comentado acima que estas suprem lacunas e atualizam a legislação de acordo com os pareceres do órgão, que conta com a participação de representantes de diversas instâncias de governo, inclusive o Ministério das Relações Exteriores, e da sociedade civil. ${ }^{42}$ Portanto, é lícito afirmar que a defesa dos direitos humanos e os acordos que são assinados com outros países em temas migratórios geram demandas para os tomadores de decisão no Brasil. Essas demandas são levadas ao conhecimento do Conselho e influenciam as suas deliberações, conforme se depreende da leitura das Atas do CNIg (Apêndice E).

\footnotetext{
${ }^{40}$ Para o ministro-chefe da Secretaria de Assuntos Estratégicos da Presidência da República (SAE), Marcelo Cortes Neri, a cifra indica que o Brasil é "um país mentalmente fechado", e que seria necessária uma mudança de cultura da sociedade brasileira: "É difícil mudar a mentalidade... Nós queremos ser uma sociedade aberta? Por que não ser uma sociedade aberta?" (FIESP, 2013).

${ }^{41}$ Conforme referido anteriormente, a partir de 2010 o fluxo de migrantes de origem haitiana se intensifica, porém esse movimento está além do escopo deste trabalho.

${ }^{42} \mathrm{~A}$ composição do CNIg é apresentada no Apêndice D.
} 
As anistias concedidas em 1998 e 2009 tiveram o objetivo de regularizar a situação migratória de vasto contingente de estrangeiros que vieram ao Brasil em busca de melhores oportunidades de emprego. A regularização permitiu-lhes obter a documentação necessária para encontrar trabalho com vínculo formal (legalizado) e reunir as condições para solicitar o visto permanente. A estabilidade econômica brasileira também constituiu fator de atração de migrantes. Segundo o Ex-Ministro da Defesa e Ex-Chanceler, Embaixador Celso Amorim:

\begin{abstract}
Não dá para se tornar a sexta economia do mundo impunemente. Normalmente, as pessoas saíam do Brasil. O Brasil ficou melhor agora. As pessoas querem entrar no Brasil. Naturalmente teremos que estudar como agir diante dessa nova situação. (...) Temos que procurar exercitar o mesmo espírito humanitário que está presente [com as Forças de Paz] no Haiti, de uma maneira compatível com os nossos meios (GLOBO, 2012b).
\end{abstract}

Essa mesma percepção repercute no discurso do Ministro da Justiça José Eduardo Cardozo, em 2014, para quem as políticas sociais do Governo Federal nos últimos dez anos tiveram como resultado uma mudança "vertiginosa" da imagem do Brasil no cenário internacional. É tendo em vista essa nova situação que o governo discute a mudança da lei de imigração.

\footnotetext{
Isso provocou o nascimento de um problema novo. Nós não vivenciávamos isso nos últimos anos, nossa estrutura administrativa não estava preparada para isso. Então agora, diante dessa realidade, nós temos que nos aparelhar (PORTAL TERRA, 2014).
}

Com relação à defesa dos direitos dos nacionais no exterior, o MRE parece empenhado no cumprimento das disposições do Decreto no 7.214, de 2010. Entre as medidas implementadas pelo Itamaraty destacam-se a criação do Portal Consular e da página "Brasileiros no Mundo" na Internet, com a disponibilização de diversas cartilhas de orientação para os emigrados sobre assuntos de interesse da comunidade, como legalização de documentos, orientações para trabalho e envio de remessas para o Brasil.

A orientação das ações de política externa em favor dos nacionais no exterior revela seu impacto na política migratória com iniciativas como a implantação da "Casa do Trabalhador" em Foz do Iguaçu, em 2008. Segundo estimativas da época, na fronteira do Brasil com o Paraguai vivam cerca de 300 mil brasileiros. Segundo o MTE, o projeto visava, por intermédio de parcerias com entidades públicas e entidades civis, qualificar os brasileiros que foram morar no exterior durante a recessão econômica dos anos 80 e 90, e que gostariam de retornar ao Brasil. Outra preocupação era "evitar que 
os brasileiros com baixa qualificação e que não possuem domínio da língua estrangeira se submetam a trabalhos considerados degradantes - um risco constante para os trabalhadores em situação clandestina" (BRASIL, 2008b).

Segundo o então Coordenador-Geral de Imigração do MTE, Paulo Sérgio de Almeida no lançamento da iniciativa:

\begin{abstract}
Vamos orientá-los sobre como eles podem obter o reconhecimento dos cursos e trabalhos que realizaram no exterior, e também oferecer cursos para que eles possam investir seu patrimônio no Brasil, abrindo seu próprio negócio. (...) Estima-se que hoje existam quatro milhões de brasileiros vivendo no exterior. O Brasil se tornou um país de emigração, e precisa de instituições preparadas para auxiliar os consulados e embaixadas a lidar com esse fenômeno. (...) Para cada centro instalado no exterior, o Governo Brasileiro se compromete a montar uma estrutura semelhante no Brasil, oferecendo os mesmos serviços aos imigrantes desses países (BRASIL, 2008b).
\end{abstract}

A esta altura, cabe o comentário de que o Estado brasileiro deixa muito a desejar em relação à prestação de serviços de apoio aos trabalhadores imigrantes, pois não há, até o momento, nenhuma estrutura oficial nos moldes do Espaço do Trabalhador Brasileiro. A assistência tem sido prestada majoritariamente por organizações da sociedade civil, como a Cáritas Brasileira, a Pastoral dos Migrantes e o Instituto Migrações e Direitos Humanos, que acolhem e encaminham migrantes e refugiados. ${ }^{43}$

Nos moldes do projeto desenvolvido no Paraguai, foi criada a "Casa do Trabalhador Brasileiro" (atualmente "Espaço do Trabalhador Brasileiro") junto ao Consulado do Brasil em Hamamatsu, no Japão. O projeto foi inaugurado em $2010 \mathrm{em}$ parceria entre o MRE e o MTE, para esclarecer dúvidas dos brasileiros sobre direitos e deveres trabalhistas no Japão e no Brasil, programas de capacitação profissional, mercado de trabalho brasileiro e japonês ou encaminhamento a serviços especializados no Japão. Segundo o MTE, “o projeto também proporciona ao governo brasileiro a chance de conhecer as condições, necessidades e demandas trabalhistas da comunidade brasileira no Japão.” A preocupação com os brasileiros que retornam do exterior, em especial do Japão, motivou a criação do Núcleo de Informação e Apoio aos Brasileiros

\footnotetext{
${ }^{43}$ Em agosto de 2014, a Secretaria Municipal de Direitos Humanos e Cidadania do Município de São Paulo criou o Centro de Referência e Acolhida para Imigrantes, com o objetivo de acolher e dar suporte a migrantes em trânsito ou residentes na cidade, independentemente da nacionalidade, status migratório ou amparo legal para a sua estada em território nacional (BRASIL, 2014b). Também em São Paulo foi aberto, em dezembro de 2014, o Centro de Integração e Cidadania do Imigrante (CIC do Imigrante, que oferecerá abrigo a pessoas resgatadas do trabalho escravo, além de cursos de capacitação e do idioma, expedição do registro de estrangeiro, inclusão bancária e expedição de carteira de trabalho, além de outros serviços (REDE, 2014).
} 
Retornados do Exterior (NIATRE), localizado no bairro da Liberdade, em São Paulo. O Núcleo atende trabalhadores retornados do exterior e oferece orientação para sua reintegração ao Brasil, o acesso a direitos e deveres relativos à cidadania brasileira e sua reinserção ao mercado de trabalho brasileiro.

Segundo o MRE, a grande maioria dos brasileiros emigrados se encontra em situação migratória irregular. Na visão do então Subsecretário-Geral para as Comunidades Brasileiras no Exterior, Embaixador Eduardo Gradilone, esse é um "aspecto fundamental a ser considerado no exame da 'diáspora' brasileira e importante condicionante para a formulação e implementação de políticas públicas em seu benefício." Entretanto, o diplomata destaca que a presença dos brasileiros

é geralmente vist[a] com muita simpatia por sociedades receptoras, como trabalhador dedicado, alegre, desvinculado de "guetos" e da criminalidade organizada. Trata-se de importante patrimônio diplomático e cultural com que conta o Brasil, constituindo sua preservação e valorização objetivos estratégicos da política governamental para a diáspora brasileira (GRADILONE, 2010).

Além de todas as razões comentadas anteriormente, o interesse pela aproximação com os migrantes brasileiros no exterior decorre de objetivos de política externa com vistas ao adensamento das relações com países estratégicos. A esse respeito, é também interessante assinalar que, em pronunciamentos oficiais, registra-se uma frequência significativa de menções, por parte de representantes do governo brasileiro, ao histórico de imigração de alguns povos, enaltecendo suas virtudes e sua contribuição para a formação do Brasil. Alguns exemplos dessa retórica são apresentados a seguir:

Este é um país que deve muito aos imigrantes, gente corajosa que deixou para trás, ao longo de séculos, a sua terra de origem em busca de oportunidades, disposta a dar o melhor de si, a crescer material e espiritualmente. (...) Graças ao Tratado de 1895, que possibilitou o início da grande imigração japonesa ao Brasil, duas terras distantes na geografia e na cultura puderam conhecer-se melhor, aproximar-se, tornar-se íntimas. Entre o Japão e o Brasil criou-se aquele elo indissolúvel entre os Estados, que nada pode afetar ou diminuir: a dimensão humana. (Ministro Lampreia, no Centenário da assinatura do Tratado de Amizade, Comércio e Navegação Brasil-Japão). (BRASIL, 1995, p. 199).

A amizade que sempre nos uniu à Alemanha tem base sólida nos vínculos familiares dos imigrantes alemães que escolheram o Brasil como pátria de adoção. Hoje, a pujança e a vitalidade que a Alemanha projeta em todo o mundo devem ser impulso adicional para o aprofundamento dessa amizade. (Discurso de FHC durante brinde ao Presidente da República Federal da Alemanha). (BRASIL, 1995, p. 199). 
Lembro que São Paulo recebeu neste século um significativo contingente de chineses, que nos ajudaram a construir a prosperidade da região mais desenvolvida do Brasil. (Discurso de FHC em jantar oferecido pelo prefeito de Xangai). (BRASIL, 1995, p. 255).

Os imigrantes japoneses que aqui chegaram, com esperança no futuro, ajudaram a construir o Brasil e a forte relação que une dois países até então distantes em termos geográficos, históricos e culturais. Passados 100 anos, nossa comunidade de origem japonesa - a maior fora do Japão - é plenamente integrada e muito admirada por suas qualidades e realizações." (Discurso de Lula no Centenário da Imigração Japonesa para o Brasil). (BRASIL, 2008c).

Embora as manifestações protocolares indiquem que o Brasil reconhece o valor dos imigrantes que contribuíram e contribuem para o desenvolvimento do País, isso não significa que deixem de ser aplicadas as sanções previstas na Lei no 6.815 , de 1980, nos casos de entrada e permanência irregulares, sancionadas com as deportações. Embora o número tenha sido relativamente pequeno no período de 1995 a 2010 (3.203 deportações, média de 200 pessoas/ano), algumas nacionalidades se sobressaem, tais como, bolivianos (696 ou 21,7\% do total), peruanos (339 ou 10,6\% do total), chineses (199 ou 6,2\%) e libaneses (175 ou 5,5\%). Em consulta realizada ao DPF por meio da Lei de Acesso à Informação, foram obtidos dados sobre o número de deportados por nacionalidade entre os anos de 1995 e 2010 (Apêndice F). Outro item da consulta realizada refere-se ao número de inadmitidos. Nesse caso o DPF enviou dados de 2008 a 2014, informando que, no período, foi recusada a entrada a 33.774 estrangeiros, o que corresponde a uma média de 4.825 pessoas/ano. Seja em relação à média anual de deportados ou de inadmitidos, os números são expressivamente inferiores à quantidade de pessoas deportadas pelos Estados Unidos, que, segundo estimativas, poderá chegar a 2 milhões durante a presidência de Barack Obama (ECONOMIST, 2014). A média anual de deportações é de aproximadamente 390 mil pessoas.

O tema dos refugiados também pode ser apontado com um dos fatores que articulam política externa e política migratória. Conforme referido anteriormente, o Brasil é signatário dos principais tratados internacionais de direitos humanos e é parte da Convenção das Nações Unidas de 1951 sobre o Estatuto dos Refugiados e do seu Protocolo de 1967. Em 1997, foi promulgada a Lei no 9.474, de 1997, a qual contempla os principais instrumentos regionais e internacionais sobre o tema.

A lei brasileira para refugiados é considerada moderna e avançada, já que engloba tanto o conceito clássico de refúgio, estabelecido pela Convenção de Genebra de 1951, quanto o ampliado, consignado na Declaração de Cartagena, de 1984. À luz da 
Convenção de 1951, o que determina a elegibilidade para concessão de refúgio é a saída de um indivíduo do país de sua nacionalidade em decorrência de perseguição política, étnica ou religiosa, com fundados temores de perseguição que possam constituir ameaça à sua vida, sendo esse perigo tão iminente que o impeça de retornar. Conforme a Declaração de Cartagena, a "violação generalizada de direitos humanos" constitui uma das causas de reconhecimento da condição de refugiado.

Em 2010, os maiores grupos de refugiados acolhidos pelo Brasil eram compostos, em sua maioria, por angolanos, colombianos, congoleses, liberianos e iraquianos, totalizando 4.359 refugiados. Segundo dados do ACNUR, em 2014, o contingente passou a ser de 7.289 refugiados de 81 nacionalidades. Os principais grupos são compostos por nacionais da Síria, Colômbia, Angola e República Democrática do Congo (RDC). O perfil vem mudando gradualmente desde 2012, quando o Brasil adotou uma cláusula de cessação de refúgio aplicável aos angolanos e liberianos, com base em orientação global expedida pelo ACNUR em junho do mesmo ano. Conforme a Portaria no 2.650/2012 do Ministério da Justiça, estes estrangeiros poderiam receber a residência permanente no país, em substituição ao status de refugiado.

Na América do Sul, o Brasil ainda é um dos países que menos recebem refugiados. Segundo dados do Banco Mundial (2010), os maiores receptores são Equador (121.249) e Venezuela (201.547), cuja maioria dos refugiados diz respeito aos deslocados pelo conflito armado na Colômbia, por força da fronteira colombiana (RODRIGUES, 2010, p. 143).

Os dados disponíveis demonstram uma sensível expansão do número de refugiados reconhecidos pelo Brasil.

Gráfico 9. Refugiados no Brasil - 1995 a 2014

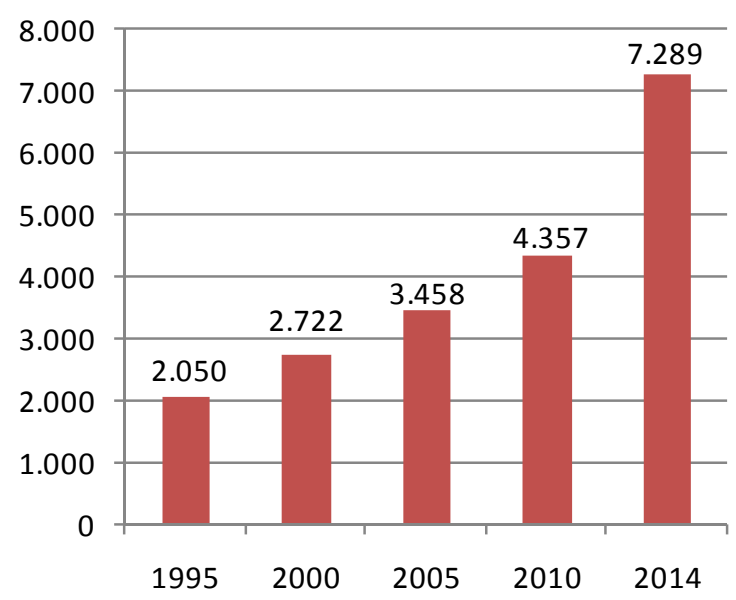

Fonte: Banco Mundial e ACNUR (2014). 
Sendo assim, verifica-se que a adesão do Brasil aos instrumentos internacionais de direitos humanos referentes às migrações e ao refúgio, e a cooperação com organizações internacionais, como o ACNUR e a OIM, em certa medida, "promovem" o Brasil como destino para migrantes e refugiados.

Embora o movimento ainda seja reduzido em relação a outros países, existe a tendência ao aumento do número de refugiados nos próximos anos.

Se, por um lado, o Estado brasileiro coopera com o ACNUR em bases regulares e dispõe de uma legislação favorável ao recebimento de refugiados, por outro, o acolhimento dos refugiados é realizado preponderantemente pela sociedade civil, que tem se mobilizado para integrá-los ao País. ${ }^{44}$ As principais críticas referem-se ao fato de que "o Poder Público permanece, ainda, bastante distante, quando não omisso, delegando à sociedade civil a efetivação desta tarefa e abstendo-se de trazer para si o cumprimento desta responsabilidade (pois) [...] as políticas públicas voltadas para a assistência e integração são essenciais para assegurar aos refugiados seus direitos econômicos, sociais e culturais" (CARLET; MILESI, 2006, p. 136, 138-139 apud BÓGUS e RODRIGUES, 2011, p. 109).

A autoras destacam 3 eixos principais de assistência: i) saúde, garantindo atendimento nos hospitais públicos, compra de medicamentos (com verbas do ACNUR repassada às ONGs) e atendimento psicológico; ii) alimentação, por meio de parceria entre ONGs e o Serviço Social do Comércio são oferecidos alimentos a baixo custo para solicitantes e refugiados e descontos nos preços das refeições; e iii) moradia, por meio de abrigos públicos, mantidos por prefeituras municipais e governos estaduais e albergues mantidos por ONGs, e, uma vez reassentado, o refugiado poderá ter seu aluguel pago pelo ACNUR por um determinado período (BÓGUS e RODRIGUES, 2011, p. 109).

Entretanto, apesar da falta de estrutura oferecida pelo Estado aos refugiados, o Brasil parece desfrutar de alto conceito nos foros internacionais encarregados do tema. Uma evidência concreta dessa boa imagem do País pode ser observada no convite formulado pela Assembleia Geral das Nações Unidas (ONU) para que o Brasil passasse

\footnotetext{
${ }^{44}$ Merece destaque o trabalho da Cáritas e do IMDH, instituições ligadas à Igreja Católica, como centros de recepção, acolhida e orientação para os refugiados.
} 
a integrar o Comitê Consultivo ${ }^{45}$ da Agência das Nações Unidas de Assistência aos Refugiados da Palestina (UNRWA, na sigla em inglês) como membro permanente. Para o Itamaraty, a inclusão do Brasil no Comitê poderá contribuir ${ }^{46} \mathrm{com}$ as forças internacionais de assistência aos refugiados palestinos, ações que fazem parte dos esforços brasileiros para a promoção da paz no Oriente Médio ${ }^{47}$ (EBC, 2014).

O Brasil pode se beneficiar dessa postura favorável ao acolhimento por estar alinhada aos princípios tradicionais pelos quais tem se pautado a política externa ao longo do tempo. Para alguns autores, como Rodrigues (2010),

[a] opção pelo multilateralismo e pelo direito internacional, a via grociana das relações internacionais, tem sido destacada por diversos analistas como o eixo principal de atuação da diplomacia brasileira desde Rio Branco. Na medida em que os temas de Direitos Humanos ganham importância na agenda internacional e que o Brasil passa a ser visto e assume atuar como fiel da estabilidade regional, por suas dimensões e por sua liderança regional benigna - aqui entendida como não confrontacionista e conciliadora de interesses regionais e globais - o terreno para aprofundar uma política internacional humanitária geral - e para os refugiados em particular - revela a sua importância (RODRIGUES, 2010, p. 139).

Logo, na medida em que o Brasil tem se valido de uma política externa proativa para se projetar como líder regional e como potência média no cenário global, aumentam as demandas por cooperação internacional para o desenvolvimento, por atuação na prevenção e mediação de conflitos e para a construção da paz.

A atuação do Brasil no cenário internacional é reconhecida pela defesa da prevalência dos direitos humanos e do multilateralismo. Nesse sentido, o País tem ampliado o escopo das ações humanitárias em nível regional e global, com ações que envolvem iniciativas unilaterais, tais como doações e cooperação técnica, e multilaterais, na forma do envolvimento em missões de paz, como a Minustah, além da promoção de cooperação técnica. Todas essas ações se inserem conceitualmente no

\footnotetext{
${ }^{45}$ O Comitê Consultivo é o órgão de mais alto nível da UNRWA, responsável pelas decisões sobre as metas e estratégias da agência. É composto por 27 membros: Alemanha, Arábia Saudita, Austrália, Bélgica, Brasil, Canadá, Dinamarca, Egito, Emirados Árabes Unidos, Espanha, Estados Unidos, Finlândia, França, Irlanda, Itália, Japão, Jordânia, Kuwait, Líbano, Luxemburgo, Noruega, Países Baixos, Reino Unido, Suécia, Suíça, Síria e Turquia. Palestina, União Europeia e Liga Árabe são observadores. O Brasil foi o primeiro país latino-americano a integrar o órgão, no final de 2014.

${ }^{46}$ Conforme comunicado da UNRWA, em 2014 o Brasil realizou doações de arroz no valor de 9,2 milhões de dólares aos refugiados assistidos pela agência. Entre os anos de 2012 e 2013, a contribuição totalizou 8 milhões de dólares (UNRWA, 2014).

${ }^{47}$ A esse respeito, cabe lembrar que o Brasil é favorável à "solução de dois Estados", com Israel e Palestina ocupando territórios que respeitem as fronteiras anteriores a 1967, reconheceu o Estado Palestino (2010) e apoiou sua entrada como membro pleno na UNESCO (2011) e como observador na ONU (2012).
} 
"princípio da não indiferença", e a política externa brasileira se dispõe a atuar, no campo humanitário dentro de uma macroestratégia de cooperação sul-sul, conforme comentado no Capítulo 1.

Os focos de desarticulação entre a política externa e a política migratória podem ser identificados em algumas instâncias decisórias que ainda se mantêm resistentes às necessárias adaptações do Estado e da sociedade para fazer frente aos desafios impostos pelo fenômeno migratório. Nesse sentido, durante o período estudado (1995 a 2010), houve momentos em que as ações de política externa não tiveram impacto sobre a política migratória, tiveram impacto muito reduzido ou seus efeitos levaram muito tempo para se manifestar. Essa desarticulação pode ser indicada como tendo origem, em grande parte, no embate entre essas instâncias, ingrediente natural nas democracias.

Emblemático dessa dinâmica é o caso da adesão do Brasil à Convenção das Nações Unidas para Proteção dos Direitos de Todos os Trabalhadores Migrantes e Membros de Suas Famílias. A assinatura, pelo Brasil, ocorreu em 1990, diante do reconhecimento das violações de direitos humanos a que os migrantes têm sido sujeitos nos países de destino, em função de sua vulnerabilidade por conta da falta de documentos. Apesar de o Ministério do Trabalho e Emprego conduzir regularmente diligências de fiscalização para coibir a exploração do trabalho de imigrantes indocumentados e de o Ministério da Justiça atuar fortemente na repressão ao tráfico de pessoas, alguns setores do governo e da sociedade impõem obstáculos à ratificação da Convenção. Essa recusa é prejudicial à imagem do Brasil, pois está em franca contradição com todas as manifestações do país em defesa dos direitos humanos dos migrantes, inclusive dos brasileiros que vivem no exterior.

Cabe lembrar, ainda, a ausência de ratificação, pelo Brasil, da Convenção no 143 da OIT, de 1975, sobre "Imigrações Efetuadas em Condições Abusivas e sobre a Promoção da Igualdade de Oportunidades e de Tratamento dos Trabalhadores Migrantes", que estabelece a garantia de igualdade de oportunidade e tratamento entre trabalhadores migrantes e nacionais.

Não obstante essas pendências, deve-se reconhecer que o Brasil tem aderido a diversas outras convenções e tratados internacionais que envolvem os direitos humanos dos migrantes. A observação de gráfico e tabela elaborados pela ONU com a evolução quantitativa das ratificações dos principais instrumentos relativos à migração internacional permite concluir que alguns documentos que têm baixa adesão por parte 
dos países membros das Organizações Internacionais a cargo do tema (OIT e ONU) também encontram resistências à sua ratificação no Brasil.

\section{Gráfico 10. Evolução da ratificação de instrumentos legais relacionados à migração internacional}

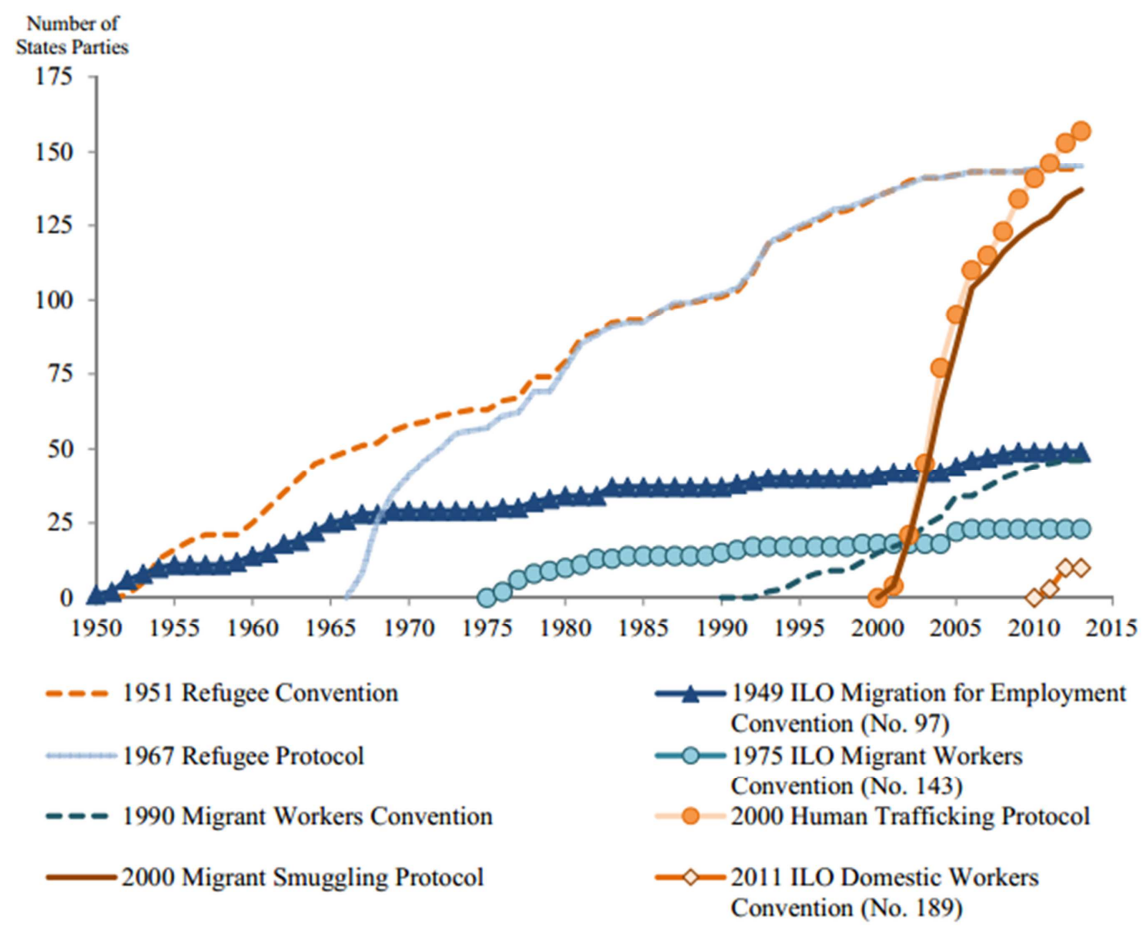

Fonte: International Migration Report (ONU, 2013c, p. 19). Gráfico elaborado pela ONU a partir de dados do United Nations Treaty Collection (http://treaties.un.org) em 1을 de dezembro de 2013 e NORMLEX - Information System on International Labour Standards (http://www.ilo.org/) .

Nota: Não inclui ratificação da Santa Sé e da União Europeia.

A tabela a seguir aponta a baixa adesão dos Estados membros da OIT à Convenção no 143 (apenas 23 dos 185 membros, o que corresponde a 12\%) e à Convenção de 1990 da ONU (47 dos 193 membros, equivalente a 24\%). Jà com relação aos refugiados e aos instrumentos relativos ao combate ao tráfico de pessoas, o Brasil já se mostra mais disposto a aderir aos compromissos internacionais.

Tabela 7. Instrumentos internacionais relativos às migrações internacionais ratificados pelo Brasil

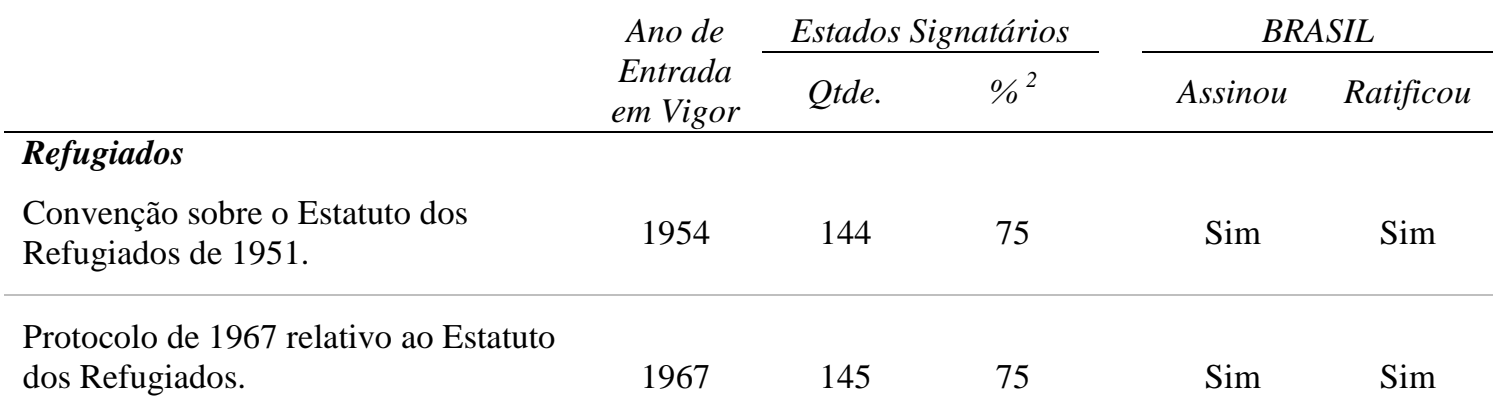




\begin{tabular}{|c|c|c|c|c|c|}
\hline & \multirow{2}{*}{$\begin{array}{l}\text { Ano de } \\
\text { Entrada } \\
\text { em Vigor }\end{array}$} & \multicolumn{2}{|c|}{ Estados Signatários } & \multicolumn{2}{|c|}{$B R A S I L$} \\
\hline & & Qtde. & $\%^{2}$ & Assinou & Ratificou \\
\hline \multicolumn{6}{|l|}{ Trabalhadores Migrantes } \\
\hline $\begin{array}{l}\text { Convenção no } 97 \text { da OIT de } 1949 \\
\text { Sobre Trabalhadores Migrantes. }\end{array}$ & 1952 & 49 & 26 & Sim & Sim \\
\hline $\begin{array}{l}\text { Convenção no } 143 \text { da OIT de } 1975 \\
\text { Sobre as Imigrações Efetuadas em } \\
\text { Condições Abusivas e Sobre a } \\
\text { Promoção da Igualdade de } \\
\text { Oportunidades e de Tratamento dos } \\
\text { Trabalhadores Migrantes. }\end{array}$ & 1978 & 23 & 12 & Sim & Não \\
\hline $\begin{array}{l}\text { Convenção Internacional de } 1990 \\
\text { Sobre a Proteção dos Direitos de } \\
\text { Todos os Trabalhadores Migrantes e } \\
\text { Membros de Suas Famílias. }\end{array}$ & 2003 & 47 & 24 & Sim & Não \\
\hline $\begin{array}{l}\text { Convenção no } 189 \text { da OIT de } 2011 \\
\text { Sobre o Trabalho Doméstico Decente. }\end{array}$ & 2013 & 10 & 5 & Sim & Não \\
\hline
\end{tabular}

\section{Contrabando e tráfico de pessoas}

Protocolo Adicional de 2000 à

Convenção das Nações Unidas Contra

o Crime Organizado Transnacional

Relativo à Prevenção, Repressão e

81

Sim Sim

Punição do Tráfico de Pessoas, em

Especial Mulheres e Crianças.

Protocolo Adicional de 2000 à

Convenção das Nações Unidas Contra

o Crime Organizado Transnacional

Relativo ao Combate ao Tráfico de

Fonte: International Migration Report (ONU, 2013c, p. 19). Tabela elaborada pela ONU a partir de dados do United Nations Treaty Collection (http://treaties.un.org) em 1o de dezembro de 2013 e NORMLEX Information System on International Labour Standards (http://www.ilo.org/). Status do Brasil: pesquisa no site de legislação da Presidência da República (http://www4.planalto.gov.br/legislacao).

Notas:

${ }^{1}$ Percentual em relação aos membros da OIT (185) e das Nações Unidas (193), conforme aplicável.

${ }^{2}$ Não inclui ratificação da Santa Sé e da União Europeia.

Pode-se compreender essa postura tendo em vista o grande apelo desses temas junto à comunidade internacional, por se tratarem de questões humanitárias. Entretanto, no que se refere especificamente aos migrantes voluntários, e sobretudo, à migração laboral, o tratamento dispensado é nitidamente diferente. Nesse ponto reside outro foco de desarticulação entre a política externa e a política migratória. 
Os refugiados contam com legislação avançada em termos de defesa dos direitos humanos, que prevê o respeito ao princípio do non-refoulement ${ }^{48}$. Já os migrantes que vêm ao Brasil em busca de trabalho encontram uma legislação rígida e discriminatória e são vistos com desconfiança pelas autoridades. Essa condição sujeita à deportação arbitrária e sem direito a recurso até mesmo os nacionais de países signatários do Acordo de Residência do Mercosul, como argentinos, bolivianos, peruanos e uruguaios (Apêndice F).

Em outubro de 2011, o Brasil sediou, pela primeira vez, a XI Conferência SulAmericana sobre Migrações (CSM), que desde o ano 2000 reúne anualmente representantes dos doze países sul-americanos e da OIM para discutir iniciativas voltadas a garantir a proteção dos direitos humanos, sociais e trabalhistas dos migrantes e a facilitar a circulação de pessoas no âmbito sul-americano. As conferências têm contado com a participação, em bases regulares, de representantes dos Ministérios da Justiça e das Relações Exteriores ${ }^{49}$.

Ao final da XI CSM, foi aprovada a Declaração de Brasília, intitulada "Rumo à Cidadania Sul-Americana”. O documento ressaltou, entre outros princípios, a importância da promoção e proteção dos direitos humanos dos migrantes, a contribuição dos migrantes ao desenvolvimento social, econômico e cultural dos países de destino e a inadmissibilidade das políticas que tipificam como crime a irregularidade migratória.

Entre as principais deliberações da Conferência, destacam-se as seguintes:

1. Reafirmar a prioridade que conferem ao respeito e à promoção dos direitos humanos dos migrantes e suas famílias, independentemente de sua condição migratória, nacionalidade, origem étnica, gênero, idade ou qualquer outra consideração, e reforçar a coordenação de posições sobre questões migratórias nos foros internacionais;

2. Reiterar sua condenação às políticas migratórias que vulneram os direitos fundamentais dos migrantes e limitam seu acesso à educação e à saúde, estimulando em muitos casos a adoção de atitudes racistas, xenófobas e discriminatórias;

3. Repudiar as políticas governamentais que tratam de forma indiferenciada migrantes indocumentados ou em situação irregular e criminosos. Condenar, em particular, diversas leis estaduais aprovadas recentemente nos Estados Unidos da América, que tipificam como delito a condição migratória irregular, o transporte e a oferta de emprego a imigrantes indocumentados (...);

4. Envidar esforços com vistas à consolidação da identidade e à construção da cidadania sul-americana, objetivos inscritos no Tratado Constitutivo da UNASUL, por meio de políticas públicas inclusivas e da adoção de

\footnotetext{
${ }^{48}$ Princípio da "não-devolução", segundo o qual nenhum país deve expulsar ou "devolver" (refouler) um refugiado, contra a vontade do mesmo para um território onde ele ou ela sofra perseguição. O tema está consignado no art. 33 da Convenção de Genebra de 1951 relativa ao Estatuto dos Refugiados.

${ }^{49}$ As conferências mais recentes foram realizadas em Santiago (2012), Cartagena (2013) e Lima (2014).
} 
iniciativas de cooperação e harmonização de políticas em matéria migratória, mediante uma abordagem integral, que assegure o mais amplo respeito aos direitos humanos e trabalhistas;

Um dos princípios que norteiam a atuação internacional do Brasil é a "prevalência direitos humanos" (art. 4º, II, da CF/1988). Cada vez mais, firma-se o entendimento de que a migração é um direito humano. Logo, a política externa, ao propugnar pelos direitos humanos dos migrantes, deverá influenciar a formulação da política migratória no sentido de promover a "gestão" ao invés do "controle" dos fluxos.

\begin{abstract}
Em matéria de políticas de migração, a globalização fará cada vez mais necessária a transição do "controle migratório" para a "gestão migratória" em um sentido amplo. Isso não significa que os Estados abandonem sua atribuição de regular a entrada de estrangeiros e supervisionar sua admissão que contemple a permanência, o retorno, a reunificação, a revinculação, o trânsito nas fronteiras e a mudança de pessoas para outros países. A proposta de análise da migração internacional como vantajosa de certa forma minimiza o caráter de enfrentamento e ausência de direitos sociais por que passam os migrantes nos países receptores (PATARRA, 2006, p. 15).
\end{abstract}

As políticas de imigração deveriam, portanto, tratar as migrações na sua complexidade e multidimensionalidade, de forma a incluí-las de forma transversal nas diversas políticas públicas. Na visão de Cavalcanti et al. (2014, p. 22), compartilhada por este trabalho, a junção entre políticas que possam acomodar os imigrantes no mercado de trabalho formal, com a perspectiva dos direitos humanos, contribuirá de forma decisiva para consolidar a imigração como um ativo valioso para o desenvolvimento do país, não somente do ponto de vista econômico, mas também cultural, social e político.

O Conselho Nacional de Imigração aprovou, em 12 de maio de 2010, para avaliação pública, proposta para a elaboração de uma Política Nacional de Imigração e Proteção ao(a) Trabalhador(a) Migrante, com o fim de "estabelecer princípios, diretrizes, estratégias, ações em relação aos fluxos migratórios internacionais, com vistas a orientar as entidades e órgãos brasileiros na atuação vinculada ao fenômeno migratório, a contribuir para a promoção e proteção dos Direitos Humanos dos migrantes e a incrementar os vínculos das migrações com o Desenvolvimento". Nesse documento, estão registrados princípios, diretrizes e ações que deverão nortear a elaboração da política em tela. A preocupação com a adoção de instrumentos de proteção aos direitos humanos, o combate à discriminação, xenofobia e racismo e a inclusão social do imigrante constituem bases importantes para a adoção de uma postura mais ativa do Estado brasileiro em relação ao tema. Esse busca por um novo 
posicionamento frente à questão das migrações internacionais se apresenta de forma muito clara em alguns dos princípios listados, quais sejam, o de que "a imigração não documentada ou irregular, é uma infração administrativa, e não está sujeita à sanção penal", e "as políticas de desenvolvimento, em âmbito nacional, regional e local, deverão considerar as migrações de forma a maximizar seus efeitos positivos”. Tal discurso parece indicar que, ao contrário de países que vêm tratando a imigração irregular como crime, com prisões e deportações de trabalhadores indocumentados, o Brasil apresenta uma abordagem mais coerente com seu histórico de receptor de fluxos de imigração, com tendência a favorecer a inclusão do estrangeiro que busca melhores condições de vida no País.

A demora na análise das propostas de ratificação da Convenção no 143 da OIT (direitos do trabalhador migrante) e da Convenção da ONU de 1990 (proteção aos trabalhadores migrantes e membros de suas famílias) denota a grande resistência por parte do Estado brasileiro e da própria sociedade em debater questões importantes relacionadas às migrações e pode indicar que alguns temores ainda subsistem.

A Lei no 6.815/80 (Estatuto do Estrangeiro) foi promulgada na vigência do Regime Militar e refletia as preocupações da época em relação à segurança nacional e à necessidade de disciplinar a entrada e a permanência de estrangeiros no território nacional. O contexto era de Guerra Fria, de contenção das ideias comunistas, consideradas "subversivas". A noção malthusiana, então em voga, alertava para o risco de esgotamento de recursos pelo aumento da população e parecia desaconselhar a abertura das fronteiras. Afinal, por que receber estrangeiros se havia temores de que os alimentos, empregos, moradias, serviços de saúde e educação oferecidos pelo Estado já seriam insuficientes para atender adequadamente os nacionais?

Hoje, porém, o contexto é bem diferente. Com a globalização, o imigrante encontra maior facilidade de comunicação e mobilidade. O intercâmbio de informações com os compatriotas emigrados (redes sociais na internet, correio eletrônico, telefonia sobre IP) se processa em grande escala e velocidade e constitui um forte apelo para a mudança. Complexo e multifacetado, o fenômeno migratório ainda não dispõe de teorias que sejam capazes de tratar do tema em todas as suas vertentes. Embora sem essa teoria unificadora, algumas teorias que explicam a continuidade das migrações, como a teoria dos sistemas de migrações - baseada nos aportes das teorias de sistemas mundiais, de redes migratórias, institucional e de causação cumulativa - sugere que os fluxos migratórios de e para o Brasil apresentam relativa estabilidade e estrutura no 
tempo e no espaço, constituindo sistemas estáveis de migração internacional. Esses sistemas estão caracterizados por um intercâmbio relativamente intenso de capitais, bens, produtos e pessoas entre alguns países, como se verifica nos casos dos sistemas Brasil-Estados Unidos, Brasil-Portugal, Bolívia-Brasil e Brasil-Japão. Registram-se, ainda, movimentos transnacionais, em que os migrantes mantêm interesses e vínculos com os lugares de origem, notadamente no caso das migrações entre Brasil e Paraguai. Cabe notar que a transnacionalidade é cada vez mais viabilizada pelas tecnologias de informação e comunicação (TICs), que possibilitam aos migrantes "estar" em dois lugares ao mesmo tempo e continuar participando da vida da comunidade que deixou ao partir.

Com base na compreensão dessas teorias e dos fenômenos que elas buscam explicar, parece razoável crer que as migrações continuarão se intensificando nos próximos anos. O International Migration Institute (IMI), da Universidade de Oxford, mapeou algumas "megatendências" para o futuro das migrações, quais sejam: as transições demográficas, com envelhecimento da população, em função da redução da fertilidade e do aumento da longevidade; aumento da urbanização nos países em desenvolvimento; expansão das redes de informação e do acesso a tecnologias de comunicação; sociedades mais diversificadas; mudança climática (IMI, 2011).

A visão dos especialistas consultados sobre o assunto, compartilhada neste trabalho, é de que o Brasil deve promover uma atualização do arcabouço jurídico referente às migrações, a fim de torná-lo mais compatível com as posturas assumidas pelo país na esfera internacional e preparar-se para a materialização da atual tendência de aumento dos fluxos migratórios nos próximos anos. A sociedade brasileira precisa ser chamada a discutir a agenda das migrações (emigração e imigração), a fim de que possa estabelecer parâmetros que definam que tipo de política atende melhor aos interesses nacionais. O Brasil poderá avançar nesse tema em consonância com seu histórico e com os objetivos de defesa dos direitos humanos dos migrantes. Para Martine (2005),

[a] globalização é parcial e inacabada, e isso afeta as migrações de várias maneiras. O dinamismo e a força principal da globalização residem na integração econômica, forjada, imposta e gerenciada pelas regras do liberalismo. Essas regras, porém, são seguidas seletivamente pelos próprios países que as promovem. O resultado é que a globalização apresenta dificuldades e morosidades no cumprimento de suas promessas. Muitos países crescem pouco ou nada e, enquanto isso, as disparidades entre ricos e pobres aumentam. Tais desigualdades contribuem para aumentar o desejo, e até mesmo a necessidade, de migrar para outros países. Entretanto, as regras do jogo da globalização não se aplicam à migração internacional: enquanto o 
capital financeiro e o comércio fluem livremente, a mão-de-obra se move a conta-gotas (MARTINE, 2005, p. 3).

A política externa brasileira é balizada por princípios que estimulam um discurso de abertura ao mundo (multilateralismo, respeito ao direito internacional, prevalência dos direitos humanos etc.). A busca por maior inserção internacional e o ânimo declarado de promover a integração regional, com vistas à formação de uma comunidade latino-americana de nações ${ }^{50}$, entre outros objetivos, são empreendimentos que impõem uma mudança de postura do governo, pois há nisso vantagens para o desenvolvimento nacional. O princípio da soberania, entretanto, ainda se impõe como limitador da circulação de pessoas através das fronteiras nacionais e está por trás da resistência brasileira em fazer as necessárias atualizações na legislação migratória.

Para o Departamento de Assuntos Econômicos e Sociais das Nações Unidas, a depender da boa governança, a migração pode proporcionar benefícios tanto para os países de origem como para os de destino:

\begin{abstract}
What we have observed over the last decades, is that migration when governed fairly, can make a very important contribution to social and economic development and that is true both in the countries of origin and (...) of destination, (...) In countries of destination, immigrants increase the productive capacity of the economy and contribute to economic growth. In their countries of origin, migration can help to alleviate problems of underemployment and through remittances can contribute to the economic and human development of those areas of the world (ONU, 2013d).
\end{abstract}

O envolvimento em foros multilaterais, como a CSM e a OIM, e o apoio às posições de consenso das Declarações indicam o grau de comprometimento do Brasil com a temática migratória. Fica evidenciado, assim, o notável potencial de influência da política externa na política migratória, uma vez que essa interação decorre de compromissos assumidos em espaços de concertação na esfera internacional que criam obrigações morais e legais para o Brasil.

Embora encontrem resistências na sua materialização, em âmbito interno, em políticas públicas que assegurem a proteção e o respeito aos direitos humanos dos migrantes, as ações de política externa do Brasil exercem pressão sobre os formuladores dessas políticas, na medida em que se verifique a necessidade de alinhar a prática ao discurso para obter uma inserção internacional mais qualificada.

\footnotetext{
50 “A República Federativa do Brasil buscará a integração econômica, política, social e cultural dos povos da América Latina, visando à formação de uma comunidade latino-americana de nações" (Art. 4º, parágrafo único, da Constituição Federal de 1988).
} 
Ao mesmo tempo, em âmbito interno, existem pressões para a manutenção das políticas mais restritivas e garantidoras da segurança e dos empregos nacionais, além de manter os contingentes de migrantes indocumentados sem acesso aos sistemas de proteção social, como saúde e educação. Essa dinâmica pode ser identificada como a que opera nos jogos de dois níveis enunciados por Putnam (1988), em que se verifica: i) o paradoxo pelo qual arranjos institucionais que fortalecem os tomadores de decisão no nível doméstico podem enfraquecer seu poder de barganha na arena internacional (e vice-versa); e ii) a potencial reverberação de pressões internacionais na agenda doméstica. Essa perspectiva contribuiria para explicar por que alguns compromissos internacionais têm impacto mais imediato na evolução da legislação e das políticas migratórias e outros não.

O capítulo que se encerra apresentou as convergências e os distanciamentos existentes entre as políticas externa e migratória, a partir do mapeamento dos compromissos internacionais assumidos pelo Brasil e das percepções de atores envolvidos na execução de ambas as políticas. Foi possível observar a ambiguidade do comportamento do Estado brasileiro em relação ao tema das migrações internacionais, que tem como resultado a validação parcial da hipótese, tema que será discutido a seguir na conclusão deste trabalho. 


\section{Conclusão}

O objetivo deste trabalho foi estudar a política externa no período de 1995 a 2010, a partir da descrição dos processos de construção da estratégia de inserção internacional do Brasil, buscando identificar pontos de convergência e distanciamento entre a política externa e a política migratória.

A atuação internacional do Brasil nos governos de FHC (1995-2002) e Lula (2003-2010) continuou sendo guiada pelas principais tradições da política externa, tais como, a opção pelo multilateralismo, o respeito ao direito internacional e aos direitos humanos. Essas linhas-mestras da política externa se mantiveram presentes nos governos FHC e Lula. Neste último, intensificou-se a atuação externa com base no discurso de solidariedade e de não indiferença, bem como a cooperação sul-sul e seu papel na projeção internacional do Brasil.

Foi testada, nesta dissertação, a hipótese segundo a qual a política externa e a política migratória, no período em tela, evoluíram de forma concertada, tendo a política externa do Brasil exercido influência sobre a política migratória.

As fontes primárias (leis, decretos, tratados, discursos) e secundárias (artigos científicos, livros, teses e dissertações) revelaram que o tema das migrações internacionais, embora ainda seja pouco frequente nos estudos acadêmicos de Relações Internacionais, normalmente tratado na esfera dos trabalhos sobre defesa e segurança, vem sendo progressivamente incluído como tema relevante, principalmente no que se refere à política externa relacionada à emigração. Nos governos FHC e Lula, as comunidades brasileiras no exterior adquiriram maior visibilidade e representatividade, obtendo maior atenção do Estado brasileiro. Isso decorreu, em parte, pelo ativismo dessas colônias, mas, principalmente, porque o Ministério das Relações Exteriores, órgão executor da política externa por competência regimental, foi orientado pelo Chefe do Executivo, o formulador dessa política em última instância, a oferecer aos brasileiros no exterior assistência consular e serviços de melhor qualidade e mais de acordo com as suas necessidades.

Como resultado dessa aproximação entre o governo e os nacionais no exterior, por meio de acordos bilaterais entre o Brasil e diversos países, foram desenvolvidos 
mecanismos que permitem a extensão de serviços da previdência social, como pagamento de contribuições previdenciárias e recebimento de pensões pelos brasileiros no exterior. Além disso, um convênio entre o MRE e a Caixa Econômica Federal permite saques do Fundo de Garantia por Tempo de Serviço (FGTS). Os residentes em países como Estados Unidos, Japão, Argentina, Bolívia, Paraguai e países da Europa (Alemanha, Áustria, Bélgica, França, Holanda, Itália, Portugal, Reino Unido e Suíça) podem solicitar autorização para o saque do FGTS junto aos consulados locais.

Quanto ao Ministério da Justiça, este executa uma política de combate ao tráfico de pessoas, buscando desbaratar redes de migração para exploração de brasileiros, operadas pelo crime organizado. Nesse sentido, o MJ trabalha para a expansão da infraestrutura de enfrentamento ao tráfico, por meio da instalação de postos avançados de atendimento humanizado ao migrante. Já o Ministério do Trabalho coordena ações de apoio aos trabalhadores brasileiros no exterior, com o Espaço do Trabalhador Brasileiro junto ao Consulado em Hamamatsu (Japão). Existe também uma preocupação com a reintegração dos brasileiros retornados, objetivo da criação de centros permanentes de apoio no Brasil, como o Núcleo de Informação e Apoio aos Brasileiros Retornados do Exterior (NIATRE). Cabe destacar o Programa Remessas, uma parceria entre a Caixa Econômica Federal e o SEBRAE, com o financiamento do Banco Interamericano de Desenvolvimento (BID), que tem por objetivo capacitar emigrantes e beneficiários de remessas que desejam abrir negócios no Brasil ou aprimorar as finanças pessoais, para que os migrantes retornados não se vejam em uma situação econômica precária após anos de trabalho no exterior (SILVA, 2013, p. 299).

Essas iniciativas na esfera das políticas migratórias para os brasileiros no exterior encontram sua origem na política externa, conforme exposto acima, o que valida parcialmente a hipótese. Já para o caso das políticas migratórias para nacionais de outros países, que buscam o Brasil para viver e trabalhar, não se verifica essa influência da política externa.

Na busca pela verificação da hipótese, no que se refere à imigração, foi realizado um mapeamento dos compromissos internacionais assumidos pelo Brasil em relação ao tema. Foram identificados dois instrumentos de maior relevância, quais sejam, o Acordo de Residência para Nacionais do Mercosul, Bolívia e Chile e a Convenção das Nações Unidas para a Proteção de Todos os Trabalhadores Migrantes e Membros de suas Famílias. O mapeamento foi confrontado com dados estatísticos de órgãos oficiais, que revelaram alto número de deportações de nacionais de países signatários do Mercosul. 
Observou-se, ainda, que até o momento não foi aprovada a ratificação da Convenção pelo Congresso, apesar do posicionamento favorável de diversas instâncias de governo.

Enquanto, na esfera internacional, o Brasil se apresentou como defensor dos direitos dos migrantes e atuou para regularização da situação migratória de indocumentados, no plano interno, as alterações na política migratória têm sido apenas pontuais e ainda carecem de maior amplitude. As anistias periodicamente concedidas apenas comprovam que o Brasil ainda pratica uma política migratória pautada no controle e na segurança, e pode ser considerado ainda "fechado à imigração", com apenas $0,3 \%$ da população composta por estrangeiros enquanto a média mundial é de 3\% (OCDE, 2013). Nesse sentido, considera-se que a hipótese não obtém validade em relação às políticas migratórias aplicáveis aos estrangeiros, pois, devido às resistências internas, não se pode afirmar que a política externa tenha exercido influência sobre a política migratória. Entre as possíveis causas para esse resultado podem estar o fato de que o Estado e a sociedade, no Brasil, ainda mantêm reservas à imigração, uma vez que a legislação migratória ainda aborda o tema no âmbito da segurança e da proteção ao trabalhador nacional. Em geral, o imigrante seria visto com desconfiança, alguém que viria ao Brasil para usufruir das riquezas nacionais e agravar os problemas sociais com os quais a sociedade já tem que lidar.

A investigação mais profunda dessas causas, porém, demandará novos estudos por parte de pesquisadores que tenham interesse em identificar as principais barreiras à evolução da política migratória no Brasil, compreender seus determinantes e apontar possíveis soluções para a superação desses impedimentos. Sugere-se, portanto, este tema como forma de aprofundamento da pesquisa realizada.

Ao longo do período estudado, foi possível observar que a política externa do Brasil se pautou por uma maior presença do País nos fóruns internacionais no que se refere à defesa dos direitos humanos. Ao mesmo tempo, o tema da migração também passou por momentos positivos, tendo sofrido a ação de variáveis endógenas (o fluxo de brasileiros emigrando para diversos países, mas mantendo vínculos com o Brasil e demandando atenção do governo brasileiro) e exógenas (a projeção do país como fator de atração de novos migrantes). Esse cenário aponta que, na medida em que seja capaz de continuar mantendo as políticas públicas de atenção aos nacionais no exterior e a imagem de país de oportunidades, o Brasil tenderá a atrair mais migrantes em busca de melhores condições de vida, sejam eles estrangeiros ou mesmo brasileiros que decidam retornar. 
Em vista das tendências atuais, que apontam para a intensificação dos movimentos migratórios em escala global, quanto mais exposto estiver o Brasil no cenário internacional e quanto mais o País se apresentar como uma nação próspera, que oferece muitas oportunidades, mais disposto deverá estar a receber migrantes e refugiados. Caso adote políticas restritivas e se mantenha fechado à imigração, poderá desperdiçar o rico capital social e cultural proporcionado pelos migrantes e comprometer sua imagem de defensor de direitos humanos e seu discurso de crítica às políticas migratórias dos países desenvolvidos. Assim, é de se esperar que, caso o Brasil faça a escolha por uma postura mais alinhada com seu histórico de receptor de migrantes, a articulação entre a política externa e a política migratória passe a ser cada vez mais evidente. Quando isso ocorrer, poder-se-á dizer que as duas políticas estarão trabalhando conjuntamente, respeitando os direitos humanos dos migrantes $\mathrm{e}$ valorizando as oportunidades proporcionadas pela mão-de-obra e a riqueza cultural dos migrantes em benefício do desenvolvimento nacional e global. 


\section{Referências Bibliográficas}

ABC. Vertentes da Cooperação Técnica Internacional. (2015). Disponível em http://www.abc.gov.br/CooperacaoTecnica/Vertentes. Acesso em 06/01/2015.

ACNUR. Dados sobre refúgio no Brasil (2010-2014). (2014). Disponível em http://www.acnur.org/t3/portugues/recursos/estatisticas/dados-sobre-refugio-no-brasil/.

Acesso em 15/01/2015.

AGÊNCIA SENADO. Senadores discutem política especial de imigração para o Haiti. Brasília, 20 dez. 2011. Disponível em http://www12.senado.gov.br/noticias/ materias/2011/12/20/senadores-discutem-politica-especial-de-imigracao-para-o-haiti. Acesso em 18/11/2013.

ALMEIDA, P. R. A política internacional do Partido dos Trabalhadores: da fundação à diplomacia do governo Lula. Revista de Sociologia Política. 2003, n.20, pp. 87-102. Disponível em http://www.scielo.br/pdf/rsocp/n20/n20a8.pdf. Acesso em 02/01/2015.

- Uma política externa engajada: a diplomacia do governo Lula. Revista Brasileira de Política Internacional. vol. 47, n.1, 2004, pp. 162-184.

A diplomacia do governo Lula: balanço e perspectivas. Disponível em http://www.pralmeida.org/05DocsPRA/1699DiplomGovLulaBalanPersp.pdf. Acesso em $05 / 01 / 2015$.

ALVES, B. C. A. Dinâmicas desnacionalizantes e a construção de novos sujeitos políticos na relação do Brasil com as comunidades brasileiras no exterior. Dissertação (mestrado)-Pontifícia Universidade Católica do Rio de Janeiro, Instituto de Relações Internacionais, 2012.

AMORIM, C. Mensagem do Ministro das Relações Exteriores. Informe MRE Comunidades Brasileiras no Exterior. n. 1, 28. jul. 2009.

Discurso na abertura do Debate Geral da 65- sessão da Assembleia-Geral das Nações Unidas. 23/09/2010. Disponível em http://www.un.org/en/ga/65/meetings/ generaldebate/Portals/1/statements/634208322910468750BR_original_language.pdf.

Acesso em 29/01/2015.

ANDRADE, J. H. F. A política de proteção a refugiados da ONU - sua gênese no período pós-guerra (1946-1952). Tese (Doutorado em Relações Internacionais) Instituto de Relações Internacionais, Universidade de Brasília, Brasília. 2006. 327 p.

ANTICO, C. Imigração Internacional no Brasil durante a década de 80: explorando alguns dados do Censo de 1991. Anais do XI Encontro Nacional de Estudos Populacionais. Caxambu. 1998.

ASANO, C. L. ; NADER, L. Reflexões sobre a Política Externa em Direitos Humanos do Governo Lula. In: Nunca antes na história desse país"...? : um balanço das 
políticas do governo Lula. Marilene de Paula (org.). Fundação Heinrich Böll: Rio de Janeiro, 2011.

BAENINGER, R. Rotatividade migratória: um novo olhar para as migrações no século XXI. ENCONTRO NACIONAL DE ESTUDOS POPULACIONAIS, 16., 2008, Caxambu. Anais. Belo Horizonte: Associação Brasileira de Estudos Populacionais ABEP, 2008. Disponível em http://www.abep.nepo.unicamp.br/encontro2008/docs PDF/ABEP2008_1254.pdf. Acesso em: outubro 2014.

BANCO Mundial. Refugee population by country or territory of asylum. Disponível em http://data.worldbank.org/indicator/SM.POP.REFG. Acesso em 22/01/2015.

BARALDI. C. Cidadania, Migrações e Integração Regional - Notas sobre o Brasil, o Mercosul e a União Européia. 3- Encontro Nacional da ABRI - Governança Global e Novos Atores n.1, v.1. (2011). Disponível em https://educarparaomundo.files. wordpress.com/2011/07/baraldi-abri-2011.pdf. Acesso em 26/01/2015.

BARRETO, L. P. T. F. Considerações sobre a imigração no Brasil contemporâneo. In: Migrações Internacionais: Contribuições para Políticas, Brasil 2000. Coordenadora Mary Garcia Castro. Brasília: CNPD, 2001. 672 p.

Refúgio no Brasil - A proteção brasileira aos refugiados e seus impactos nas Américas. Acnur-Conare-Ministério da Justiça, 2010.

Entrevista ao programa "Entre Aspas" da Globo News. 2012. Disponível em www.youtube.com/watch?v=x VY2fqiQoR8. Acesso em 25/06/2012.

BARROS, S. R. A execução da política externa brasileira: um balanço dos últimos 4 anos. Revista Brasileira de Política Internacional. 1998, vol. 41, n. 2, pp. 18-28. Disponível em http://www.scielo.br/pdf/rbpi/v41n2/v41n2a02.pdf. Acesso em 19/01/2015.

BÓGUS, L. M. M. ; RODRIGUES, V. M. Os refugiados e as políticas de proteção e acolhimento no Brasil: História e Perspectivas. Dimensões, vol. 27, 2011, p. 101-114. Disponível em http://www.periodicos.ufes.br/dimensoes/article/view/2585/2081. Acesso em 22/01/2015.

BRASIL. Ministério das Relações Exteriores. Resenha de Política Externa Brasileira, a.22, n. 76, 1을 semestre 1995 .

Ministério das Relações Exteriores. Resenha de Política Externa Brasileira, a. 24, n. 80, 1을 semestre 1997.

Senado Federal. Relatório Final da Comissão Mista Parlamentar de Inquérito. 2006. Disponível em http://www.senado.gov.br/comissoes/cpi/emigracao/ relfinalcpmiemigracao.pdf. Acesso em 18/10/2014.

. Ministério do Trabalho e Emprego. Contribuições para a construção de políticas públicas voltadas à migração para o trabalho. (2008a). Disponível em 
http://portal.mte.gov.br/data/files/8A8181FA2C136B7A012C142F4D36750F/Documen toFinalDial,39706,5803009259.pdf. Acesso em 15/01/2015.

. Ministério do Trabalho e Emprego. Lupi lança Casa do Trabalhador Brasileiro. Notícia de 20/06/2008. (2008b) Disponível em http://portal.mte.gov.br/imprensa/lupi-lanca-casa-do-trabalhador-brasileiro.htm. Acesso em $20 / 01 / 2015$.

- Ministério das Relações Exteriores. Resenha de Política Externa Brasileira, a.35, n. 106, 1ํ- semestre 2008. (2008c).

Ministério do Trabalho e Emprego. Política Nacional de Imigração e Proteção ao(a) Trabalhador(a) Migrante. (2010a). Disponível em http://portal.mte.gov.br/lumis/portal/file/fileDownload.jsp?fileId=8A7C816A4519EC52 01453C5DB5593217. Acesso em 05/06/2012.

Ministério das Relações Exteriores. Balanço de Política Externa 20032010. (2010b). Disponivel em www.itamaraty.gov.br. Acesso em 31/10/2012.

Ministério das Relações Exteriores. Exposição de Motivos no 190 MRE DTS/DNU/DDH/DAI-STES SHUM ONU. 30 de abril de 2010. (2010c). Disponível em http://www.camara.gov.br/sileg/integras/917816.pdf. Acesso em 09/08/2014.

. Ministério das Relações Exteriores. Diplomacia Consular, 2007 a 2012. Brasília: Fundação Alexandre de Gusmão, 2012.

. Lei no 6.815/1980. Disponível em http://www.planalto.gov.br/ ccivil_03/leis/16815.htm. Acesso em 08/08/2014.

. Lei no 11.961/2014. Disponível em http://www.planalto.gov.br/ccivil_03/ _Ato2007-2010/2009/Lei/L11961.htm. Acesso em 08/08/2014.

Ministério do Trabalho e Emprego. Notícia. Estudo analisa migração haitiana no Brasil. (2014a). Disponível em http://portal.mte.gov.br/imprensa/estudoanalisa-migracao-haitiana-no-brasil.htm. Acesso em 15/01/2015.

. Secretaria Municipal de Direitos Humanos e Cidadania da Prefeitura de São Paulo. Município cria Centro de Referência e Acolhida para Imigrantes. 24/07/2014. (2014b). Disponível em http://www.prefeitura.sp.gov.br/cidade/secretarias/ direitos_humanos/noticias/?p=175415. Acesso em 15/01/2015.

BRITO, Fausto. A politização das migrações internacionais: direitos humanos e soberania nacional. Belo Horizonte : UFMG/CEDEPLAR, 2011.

CÂMARA DOS DEPUTADOS. Projeto de Lei no 5.655, de 2009. Disponível em http://www.camara.gov.br/proposicoesWeb/fichadetramitacao?idProposicao=443102. Acesso em 28/06/2012.

CAMPOS, M. B. Estimativas de migração internacional no Brasil: velhos e novos desafios. In: Reflexões sobre os deslocamentos populacionais no Brasil. Série 
Estudos e Análises. Informação Demográfica e Socioeconômica. Vol. 1. 2011. Disponível em http://www.ibge.gov.br/home/estatistica/populacao/reflexoes_deslocame ntos/deslocamentos.pdf. Acesso em 25/012015.

CARDOSO, F. H. Mãos à obra, Brasil: proposta de governo. Brasília, 1994.

A política externa do Brasil no início de um novo século: uma mensagem do Presidente da República. Revista Brasileira de Política Internacional. v. 44 (1): 512, 2001. Disponível em http://www.scielo.br/pdf/rbpi/v44n1/a01v44n1.pdf. Acesso em 05/01/2015.

CARDOZO, S. A. ; MIYAMOTO, S. Política externa brasileira em dois momentos: uma análise comparativa entre a política externa do governo Geisel e do governo Lula. Trabalho apresentado no 5o Encontro da Associação Brasileira de Ciência Política (ABCP), UFMG, Belo Horizonte, 26-29 jul. 2006.

CARLET, F.; MILESI, R. Refugiados e políticas públicas. In: RODRIGUES, Viviane Mozine (Org.). Direitos humanos e refugiados. Vila Velha/Espírito Santo: Nuares Centro Universitário Vila Velha; ACNUR; IMDH, 2006. p. 123-150.

CARVALHO, Cleide. Acre sofre com invasão de imigrantes do Haiti. O Globo Online, edição de 01/01/2012. Disponível em http://oglobo.globo.com/pais/acre-sofre-cominvasao-de-imigrantes-do-haiti-3549381. Acesso em 15/06/2012.

CASTLES, S. ; MILLER, M. J. The age of migration: international population movements in the modern world. 4- ed. Londres: Palgrave Macmillan, 2009.

CASTRO, M. Migrações internacionais e políticas: algumas experiências internacionais. In: CNPD. Migrações Internacionais - Contribuições para políticas. Brasília: s. n., 2001.

CAVALCANTI, L. Imigrantes, imigrados, estrangeiros... e a fabricação do outro imaginário. A presença brasileira no contexto da imigração na Espanha. Revista: Universitas Comunicação, v. 3, p. 37-52, 2005.

OLIVEIRA, A. T. ; TONHATI, T. (Orgs.) A inserção dos imigrantes no mercado de trabalho brasileiro. Brasília: Cadernos do Observatório das Migrações Internacionais. 2014. Disponível em: <http://portal.mte.gov.br/obmigra/imigracao>. Acesso em: 20/11/2014.

PARELLA, S. El retorno desde una perspectiva transnacional. Revista Interdisciplinar de Mobilidade Humana - REMHU. v. 21, p. 9-20, 2013.

; SIMOES, G. Assimilacionismo x multiculturalismo: reflexões teóricas sobre os modelos de recepção dos imigrantes. ESFERAS - Revista Interprogramas de Pósgraduação em Comunicação do Centro Oeste, v. 3, p. 153, 2013.

; TONHATI, T. As migrações internacionais no Brasil: construindo ferramentas para análise. Observatório das Migrações Internacionais no Brasil. 
2014. Disponível em http://periodicos.unb.br/index.php/obmigra/article/view/12953/9 126. Acesso em 31/01/2015.

CERVO, A. L. Relações internacionais do Brasil: um balanço da era Cardoso. Revista Brasileira de Política Internacional. 45 (1), pp. 5-35, 2002. Disponível em http://www.scielo.br/pdf/rbpi/v45n1/a01v45n1.pdf. Acesso em 05/01/2015.

Política exterior e relações internacionais do Brasil: enfoque paradigmático. Revista Brasileira de Política Internacional. Brasília, ano 46, no. 1, 2003.

Saraiva, 2008.

Inserção internacional: formação dos conceitos brasileiros. São Paulo:

. Brazil's Rise on the International Scene: Brazil and the World. Revista Brasileira de Política Internacional. 2010, vol.53, n.spe, pp. 7-32. Disponível em http://www.scielo.br/pdf/rbpi/v53nspe/v53nspea02.pdf. Acesso em 20/01/2015.

CEPAL. O investimento estrangeiro direto na América Latina e Caribe. 2010. Disponível em http://www.cepal.org/id.asp?id=39435. Acesso em 27/12/2014.

CGEE. População e políticas sociais no Brasil: os desafios da transição demográfica e migrações internacionais. 2008. Disponível em http://www.cgee.org.br/publicacoes/ demografica.php. Acesso em 20/10/2014.

CLARO. C. A. B. As Migrações Internacionais no Brasil sob uma perspectiva jurídica: análise da legislação brasileira sobre estrangeiros entre os séculos XIX e XXI. Cadernos do Observatório das Migrações Internacionais. 2014. Disponível em http://periodicos.unb.br/index.php/obmigra/article/view/12961/9134. Acesso em 31/01/2015.

COENTRO, L. U. Políticas Públicas e Gestão das Migrações Internacionais no Brasil: Uma Reflexão Sobre os Migrantes Qualificados. Dissertação (mestrado) Escola de Administração de Empresas de São Paulo. Fundação Getúlio Vargas. 2011.

CORBETT, J. Ernest George Ravenstein: The Laws of Migration, 1885. Center for Spatially Integrated Social Science. 2011. Disponível em http://www.csiss.org/ classics/content/90. Acesso em 09/01/2014.

DANESE, S. Diplomacia Presidencial. Rio de Janeiro : Ed. Topbooks, 1999.

Audiência na Câmara dos deputados em 15/10/2013. Disponível em http://imagem.camara.gov.br/internet/audio/Resultado.asp?txtCodigo $=46088$. Acesso em $27 / 07 / 2014$.

EMPRESA BRASILEIRA DE COMUNICAÇÃO (EBC). Imigração: cresce número de estrangeiros no Brasil; há menos brasileiros no exterior. 11/12/2012. Disponível em http://www.ebc.com.br/noticias/retrospectiva-2012/2012/12/retrospectivaimigracao. Acesso em 08/08/2014. 
. Brasil vai integrar comitê de assistência a refugiados palestinos. 12/12/2014. Disponível em http://agenciabrasil.ebc.com.br/internacional/noticia/201412/brasil-vai-compor-comite-de-assistencia-refugiados-palestinos. Acesso em 23/01/2015.

ECONOMIST. America's deportation machine: The great expulsion. 08/02/2014. Disponível em http://www.economist.com/news/briefing/21595892-barack-obama-haspresided-over-one-largest-peacetime-outflows-people-americas. Acesso em 22/01/2015.

ESTADO de São Paulo. Brasil anistia 41.816 estrangeiros em situação irregular. Disponível em http://politica.estadao.com.br/noticias/geral,brasil-anistia-41816estrangeiros-em-situacao-irregular,491657. Acesso em 15/01/2015.

FELDMAN, L. Três atos da "consularização" da diplomacia brasileira. Política Externa. Vol. 17, no 4, Mar/Abr/Mai 2009. São Paulo : Ed. Paz e Terra. pp. 89-101.

FIESP. Com taxa de imigração abaixo do normal, Brasil se mostra fechado para estrangeiros, reconhece ministro da SAE. 12/06/2013. Disponível em http://www.fiesp.com.br/noticias/com-taxa-de-imigracao-abaixo-do-normal-brasil-semostra-fechado-para-estrangeiros-reconhece-ministro-da-sae/. Acesso em 27/01/2015.

FOLHA de São Paulo. FHC diz que privatização vai abater dívida pública. Edição eletrônica de 17 de julho de 1997. Disponível em http://www1.folha.uol.com.br/ fsp/dinheiro/fi170714.htm. Acesso em 05/01/2014.

FONSECA, C. A política externa brasileira da democracia: O paradoxo da mudança na continuidade? Relações Internacionais. 2011, n. 29, pp. 33-43. Disponível em http://www.scielo.gpeari.mctes.pt/pdf/ri/n29/n29a03.pdf. Acesso em 28/01/2015.

GLOBO Online. 'Brasiguaios' são desafio ao Itamaraty. Editorial. Edição eletrônica. (2012a). Disponível em http://oglobo.globo.com/opiniao/brasiguaios-sao-desafio-aoitamaraty-3862575. Acesso em 15/01/2015.

Política de imigração brasileira precisa ser revista, diz Amorim. (2012b). Disponível em http://oglobo.globo.com/pais/ politica-de-imigracao-brasileiraprecisa-ser-revista-diz-amorim-3660191. Acesso em 27/06/2012.

GLICK SCHILLER, Nina. Transmigrants and the Nation-States: Something Old and Something New in the U.S. Immigrant Experience. In: The Handbook of International Migration: The American Experience. Hirschman, C. Kasinitz, P. DeWind, J. (editors). Russell Sage Foundation. New York. 1999.

GOMES. L.; MAZZUOLI. V. O Brasil e o Sistema Interamericano de Proteção dos Direitos Humanos. Associação Internacional de Direito Penal. 2005. Disponível em http://www.aidpbrasil.org.br/arquivos/anexos/o_brasil_e_o_sistema_interamericano_de _direitos_humanos.pdf. Acesso em 30/01/2015.

GRADILONE, E. A política consular e de apoio a brasileiros como fator de credibilidade e afirmação externa do Brasil. Disponível em http://sistemas.mre. 
gov.br/kitweb/datafiles/IRBr/pt-br/file/CAD/SGEB\%20-\%20Palestra\%20SGEB\%20na \%20CNPEPI-FUNAG\%202010.pdf. Acesso em 20/01/2015.

HUJO, K.; PIPER, N. South-South Migration - Implications for Social Policy and Development. New York: Palgrave Macmillan. 2010

IBGE. Séries Estatísticas. Disponível em http://seriesestatisticas.ibge.gov.br/series. aspx ?vcodigo $=\mathrm{CD} 105 \& \mathrm{t}=$ migracoes-estrangeiros-naturalizados-censos-demograficos. Acesso em 20/01/2015.

IGLESIAS PUENTE, C. A. A cooperação técnica horizontal brasileira como instrumento de política externa: a evolução da cooperação técnica com países em desenvolvimento - CTPD - no período 1995-2005. Brasília : FUNAG, 2010. 340p.

IMI. Global 'Megatrends' for Future International Migration. International Migration Institute. University of Oxford. Policy briefing 9, September 2011. Disponível em http://www.imi.ox.ac.uk/pdfs/projects/gmf-pdfs/pb-11-9-global-megatrends-for-futureinternational-migration/view. Acesso em 25/01/2015.

IPEA. Cooperação Brasileira para o Desenvolvimento Internacional: 2005-2009. Brasília : Ipea : ABC, 2010. 78 p.

Cooperação Brasileira para o Desenvolvimento Internacional: 2010. Brasília : Ipea : ABC, 2013. 124 p.

KING, G.; KEOHANE, R.; VERBA, S. Designing social inquiry. London: Princeton University Press, 1996.

KING, N. Using interviews in qualitative research. In: SYMON, G.; CASSELL, C. (Org.), Essential guide to qualitative methods in organizational research. London: Sage, 2004, cap. 2.

KRISSMAN, F. Sin coyote ni patrón: why the "migrant network" fails to explain international migration. International Migration Review, v. 39, n. 1, p. 1-44, 2005.

LAGO, A. A. C. Estocolmo, Rio, Joanesburgo: o Brasil e as três conferências ambientais das Nações Unidas. Brasília: FUNAG, 2006.

LAMPREIA, L. F. A política externa do governo FHC: continuidade e renovação. Revista Brasileira de Política Internacional. vol. 41, n. 2, 1998, pp. 5-17. Disponível em http://www.scielo.br/pdf/rbpi/v41n2/v41n2a01.pdf. Acesso em $\underline{05 / 01 / 2015}$.

FGV, 2010.

Luiz Felipe Lampreia (depoimento, 2008). Rio de Janeiro, CPDOC-

LESSA, A. C. Cada um com o que é seu: as migrações internacionais e a diáspora brasileira. Boletim Meridiano 47. no 113, dez. 2009. p. 6-9. 
LIMA. M. R. S. A política externa brasileira e os desafios da cooperação sul-sul. Revista Brasileira de Política Internacional. vol.48 no.1 Brasília Jan./June 2005. Disponível em http://www.scielo.br/scielo.php?script=sci_arttext\&pid=S003473292005000100002. Acesso em 28/12/2014.

LOPES, C. M. S. Direito de imigração: o Estatuto do Estrangeiro em uma Perspectiva de Direitos Humanos. Porto Alegre: Núria Fabris, 2009.

LOPES, D. B. A política externa brasileira e a "circunstância democrática": do silêncio respeitoso à politização ruidosa. Revista Brasileira de Política Internacional. vol.54 no.1 Brasília 2011. Disponível em http://www.scielo.br/pdf/rbpi/ v54n1/v54n1a05.pdf. Acesso em 28/12/2014.

LULA DA SILVA, L. I. Carta aos brasileiros que vivem longe de casa. Disponível em http://lulaforpresident.tripod.com/carta.htm. (2002). Acesso em 10/11/2014.

Metas Voluntárias em direitos humanos. Discurso no Conselho de Direitos Humanos da ONU. Política Externa, vol. 18, no 2, set/out/Nov. 2009a.

Discurso durante cerimônia de sanção da lei que anistia estrangeiros em situação irregular no Brasil em 02/07/2009. Ministério da Justiça. Brasília-DF. 2009b.

MARTES, A. C. B. Velho tema, novos desafios - Gestão pública da imigração. In: Peter Fischer-Bollin. (Org.). Cadernos Adenauer. X (2009), no 1 - Migração e políticas sociais. Rio de Janeiro: Fundação Konrad Adenauer, 2010, v.2, p. 9-28.

MARTINE, G. A globalização inacabada: migrações internacionais e pobreza no século 21. São Paulo em Perspectiva. vol.19, n.3, 2005. pp. 3-22. Disponível em http://www.scielo.br/pdf/spp/v19n3/v19n3a01.pdf. Acesso em 15/01/2015.

MASSEY, D. et al. Theories of international migration: a review and appraisal. Population and Development Review, v. 19, n. 3, p.431-466, 1993.

Why Does Migration Occur? A Theoretical Synthesis. In: The Handbook of International Migration: The American Experience. Hirschman, C. Kasinitz, P. DeWind, J. (editors). Russell Sage Foundation. New York. 1999.

Theories of international migration: a review and appraisal. In: MESSINA, A. L. (Org.), The migration reader exploring politics and policies. Londres: Lynne Rienner, 2006.

MELLO, F. C. O Brasil e o Multilateralismo Contemporâneo. IPEA, Texto para Discussão 1628 (Rio de Janeiro), 2011.

O Multilateralismo na Política Externa Brasileira, Carta Internacional. vol. 7, n. 2, jul.-dez. 2012 [p. 163 a 173].

MILANEZ, L. C. B. M. Brasileiros no Exterior: Formulação de Política Externa e Formação de Comunidades. Dissertação (mestrado). Universidade de Brasília, Instituto de Relações Internacionais, 2013. 
MILESI, R. Regularização de Imigrantes no Brasil, pelo sistema do Registro Provisório - Anistias de 1981, 1988 e 1998. Instituto Migrações e Direitos Humanos. 2009. Disponível em http://www.migrante.org.br/anistias_no_brasil_artigo_rosita_05 jun09.doc. Acesso em 15/01/2015.

. Por uma nova Lei de Migração: a perspectiva dos Direitos Humanos. Instituto Migrações e Direitos Humanos. 2007. Disponível em http://www.migrante.org.br/textoseartigos.htm. Acesso em 31/01/2015.

NYE, J. R. Soft Power: the Means to Success in World Politics. Nova York, Public Affairs. ed. 2005.

OCDE. World Migration in Figures. 2013. Disponível em http://www.oecd.org/els/mig/World-Migration-in-Figures.pdf. Acesso em 31/01/2015.

OIM. Glossário sobre Migração. Direito Internacional da Migração. no 22 (2009). Disponível em http://publications.iom.int/bookstore/free/IML22.pdf. Acesso em $\underline{15 / 01 / 2015}$.

development. 2009.

Human Develop Report. Overcoming barriers: Human mobility and

ONU. International migration and development. Report of the Secretary-General. A/60/871. 18/05/2006. Disponível em http://www.un.org/esa/population/migration/hld/ Text/Report\%20of\%20the\%20SG(June\%2006)_English.pdf. Acesso em 27/01/2015.

Globalization and interdependence: international migration and development Draft resolution submitted by the President of the General Assembly Declaration of the High-level Dialogue on International Migration and Development. A/68/L.5. 01/10/2013 (2013a). Disponível em http://www.un.org/ga/search/view doc.asp?sym bol=A/68/L.5. Acesso em 28/01/2015.

Population Facts No. 2013/2. September 2013. Department of Economic and Social Affairs. Population Division. (2013b). Disponível em http://esa.un.org/unmigration/documents/The_number_of_international_migrants.pdf . Acesso em 27/01/2015.

International Migration Report 2013. Department of Economic and Social Affairs. Population Division. (2013c) Disponível em http://www.un.org/en/development/desa/population/publications/pdf/migration/migratio nreport2013/Full_Document_final.pdf. Acesso em 27/01/2015.

Focusing on new trends in migration. 19/04/2013. (2013d). Disponível em http://www.un.org/en/development/desa/news/population/cpd46-trends-in-migration

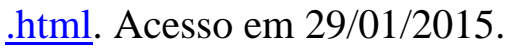

PATARRA, N. L. Migrações internacionais de e para o Brasil contemporâneo: volume, fluxos, significados e políticas. Revista São Paulo em Perspectiva, v. 19, n. 3, p. 2333, 2005. Disponível em http://www.scielo.br/pdf/spp/v19n3/v19n3a02.pdf. Acesso em 25/01/2015. 
Migrações internacionais: teorias, políticas e movimentos sociais. Estudos Avançados, 20(57). São Paulo: EDUSP, 2006.

- Políticas Públicas e Migração Internacional no Brasil. In: L. M. Chiarello, ed. Las Políticas Públicas sobre Migraciones y La Sociedad Civil en América Latina. São Paulo: Scalabrini International Migration Network, pp. 151-276, 2011.

PECEQUILO, C. S. A política externa do Brasil no século XXI: os eixos combinados de cooperação horizontal e vertical. Revista Brasileira de Política Internacional. 2008, vol.51, n.2, pp. 136-156. Disponível em http://www.scielo.br/pdf/ rbpi/v51n2/v51n2a09.pdf. Acesso em 03/01/2015.

2012,354 p.

Manual do Candidato - Política Internacional. Brasília : FUNAG,

PORTAL TERRA. Governo prepara projeto para alterar lei de imigrantes no Brasil. 31/05/2014. Disponível em http://noticias.terra.com.br/brasil/governo-preparaprojeto-para-alterar-lei-de-imigrantes-no-brasil,adf9ae524ef46410VgnCLD200000 b0bf46d0R CRD.html. Acesso em 20/01/2015.

PORTO, V. A Aplicação do Princípio da Reciprocidade no Direito Internacional Público: do Bilateralismo à Supranacionalidade. Direito Público. no 26. Brasília: mar/abr. 2009.

PUTNAM, R. Diplomacy and domestic politics: the logic of two-level games. International Organization n. 42, 3, Summer 1998. Disponível http://www.ou.edu/ uschina/ texts/Putnam88Diplomacy.pdf. Acesso em 31/01/2015.

RAMOS, A. C; VENTURA, D; DALLARI, P; REIS, R. Uma Lei de Migrações para o Brasil. Opinião. Folha de São Paulo. 14/09/2014. Disponível em http://www1.folha.uol.com.br/opiniao/2014/09/1515395-andre-de-carvalho-ramos-deisy -ventura-pedro-dallari-e-rossana-reis--uma-lei-de-migracoes-para-o-brasil.shtml.

Acesso em 25/01/2015.

REDE Brasil Atual. Centro de atendimento a imigrante é inaugurado na Barra Funda com apoio do MPT-SP. 15/12/2014. (2014). Disponível em http://www.redebrasilatual.com.br/cidadania/2014/12/centro-de-atendimento-a-imigran te-e-inaugurado-na-barra-funda-com-apoio-do-mpt-sp-5052.html. Acesso em 20/01/2015.

REIS, R. R., Soberania, direitos humanos e migrações internacionais. Revista Brasileira de Ciências Sociais, junho, 19(55), pp. 149-163. 2004.

A política do Brasil para as migrações internacionais. Contexto Internacional. Jan/Jun.33(1). 2011. 
. Soberania, direitos humanos e migrações internacionais. Revista Brasileira de Ciências Sociais. São Paulo, v. 19, n. 55, p.149-164, jun. 2004. Disponível em: <http://www.scielo.br/pdf/rbcsoc/v19n55/a09v1955.pdf>. Acesso em: 12 mar. 2013.

ROCHA, A. J. R. Segurança internacional e segurança humana. In: NASSER, Reginaldo Mattar (Org.). Novas perspectivas sobre os conflitos internacionais. São Paulo: UNESP, 2010, v. 1, p. 191-204.

ROCHA PAIVA, L. E. Integração da Panamazônia - Desafios, Estratégias, Tendências e Reflexos para a Defesa Nacional. Secretaria de Assuntos Estratégicos. (Núcleo de Estudos Prospectivos). Estado-Maior do Exército. Junho de 2013. Disponível em http://www.eme.eb.mil.br/ceeex/public/arquivos/nep2012/2013/02.Artigo_Rocha_Paiva T1.pdf. Acesso em 15/01/2015.

RODRIGUES. G. M. A. O futuro do refúgio no Brasil e seu papel no cenário humanitário. In: BARRETO. L. P. T. F. (org.). Refúgio no Brasil - A proteção brasileira aos refugiados e seus impactos nas Américas. Acnur-Conare-Ministério da Justiça, 2010. pp. 134-149.

SALES, C. M. R. Relações Internacionais e Política externa do Brasil nos governos FHC e Lula. Dissertação (Mestrado em Ciência Política). Instituto de Filosofia e Ciências Humanas - IFCH. Universidade Estadual de Campinas, 2007.

SALOMÓN, M; PINHEIRO, L. Análise de Política Externa e Política Externa Brasileira: trajetória, desafios e possibilidades de um campo de estudos. Revista Brasileira de Política Internacional. vol.56 no.1 Brasília 2013. Disponível em http://www.scielo.br/scielo.php?pid=S0034-73292013000100003\&script=sci_arttext. Acesso em 28/122014.

SARAIVA, M. G. Brazilian foreign policy towards South America during the Lula Administration: caught between South America and Mercosur. Revista Brasileira de Política Internacional. 53 (special edition) 2010. pp. 151-168 .

SAYAD, A. A Imigração ou Os Paradoxos da Alteridade. São Paulo: Editora da Universidade de São Paulo, 1998.

SCHENONI, L. L. As possíveis causas domésticas da liderança brasileira na América do Sul. Contexto Internacional. vol.34 no.2 Rio de Janeiro Dec. 2012. Disponível em http://www.scielo.br/scielo.php?script=sci_arttext\&pid=S0102-85292012000200009

SCHWEIZER, L. Remessas de Brasileiros no Exterior. In: Brasileiros no Mundo: I Conferência sobre as Comunidades Brasileiras no Exterior. Brasília: Fundação Alexandre de Gusmão, 2008. 379p.

SICILIANO, A. L. A política migratória brasileira: limites e desafios. Dissertação (Mestrado em Relações Internacionais) - USP. São Paulo, 2013.

SILVA, D. A. O Brasil nas migrações internacionais. In: SARAIVA, J. F.S.; CERVO, A. L. (orgs.). $O$ crescimento das Relações Internacionais no Brasil. Brasília: Instituto Brasileiro de Relações Internacionais (IBRI), 2005. 
SILVA. L. L. Políticas de apoio aos imigrantes retornados: iniciativas da área consular do Ministério das Relações Exteriores do Brasil. Revista Interdisciplinar da Mobilidade Humana. Centro Scalabriniano de Estudos Migratórios. v. 21, n. 41, 2013. pp. 295-304.

SOUZA NETO, D. M. A política externa brasileira nos oito anos do Governo Lula: legados e lições para a inserção do Brasil no mundo. In: PAULA, M. (org.) Nunca antes na história desse país...? - um balanço das políticas do governo Lula. Rio de Janeiro : Fundação Heinrich Böll, 2011.

STEINER, N. International Migration and Citizenship Today. Routledge, 2009.

UNCTAD. Base de dados estatísticos. Disponível em http://unctad.org/en/pages/ Statistics.aspx. Acesso em 05/01/2015.

UNRWA. Brazil and UAE admitted to UNRWA's top consultative body, the Advisory Commission. 09/12/2014. Disponível em http://www.unrwa.org/ newsroom/press-releases/brazil-and-uae-admitted-unrwa\%E2\%80\%99s-top-consultativ e-body-advisory-commission. Acesso em 23/01/2015.

USHIJIMA, F. R. A Política Externa Brasileira para os Emigrantes e seus Descendentes. São Paulo : Cultura Acadêmica, 2012. 251 p. Disponível em http://acervo-digital.espm.br/e-books/325344.pdf. Acesso em 29/01/2015.

VALLER FILHO, W. O Brasil e a crise haitiana: a cooperação técnica como instrumento de solidariedade e de ação diplomática. Brasília : FUNAG, 2007. 396 p.

VENTURA, D; ILLES, P. Qual a política migratória do Brasil? Le Monde Diplomatique Brasil. [Online] Disponível em http://www.diplomatique. org.br/artigo.php?id=1121. Acesso em 20/10/2014.

VERTOVEC, S. Conceiving and researching transnationalism. Ethnic and racial studies, v. 22, n.2, mar. 1999, p. 447-462.

VIGEVANI, T. ; OLIVEIRA, M. F. ; CINTRA, R. Política externa no período FHC: a busca de autonomia pela integração. Tempo social. 2003, vol.15, n.2, pp. 31-61. ISSN 0103-2070.

. ; CEPALUNI, G. "A política externa de Lula da Silva: A estratégia da autonomia pela diversificação". Contexto Internacional, v. 29, n. 2, p. 273-335. ago. 2007.

VILELA, E; NEIVA, P. Temas e regiões nas políticas externas de Lula e Fernando Henrique: comparação do discurso dos dois presidentes. Revista Brasileira de Política Internacional. vol.54 no.2 Brasília 2011. Disponível em http://www.scielo.br/scielo. php?script=sci_arttext\&pid=S0034-73292011000200004. Acesso em 28/12/2014.

VIZENTINI, P. F. De FHC a Lula: uma década de política externa (1995-2005). Civitas - Revista de Ciências Sociais. v. 5. n. 2, jul.-dez. 2005, pp. 381-397. 


\section{Apêndice A - Expansão da rede consular}

Representações Diplomáticas e Consulares criadas ou reabertas no período de 1995 a 2010

\begin{tabular}{|c|c|c|c|}
\hline$\#$ & $\begin{array}{c}\text { CRIAÇÃO/ } \\
\text { REABERTURA }\end{array}$ & POSTO & CATEGORIA \\
\hline 1 & 1995 & Houston - EUA & Consulado-Geral \\
\hline 2 & 1995 & Tóquio - Japão & Consulado-Geral \\
\hline 3 & 1996 & Wellington - Nova Zelândia & Embaixada \\
\hline 4 & 1999 & Xangai - China & Consulado-Geral \\
\hline 5 & 2001 & Córdoba - Argentina & Consulado-Geral \\
\hline 6 & 2002 & Dili - Timor Leste & Embaixada \\
\hline 7 & 2002 & Ierevan - Armênia & Embaixada \\
\hline 8 & 2003 & São Tomé - São Tomé e Príncipe & Embaixada \\
\hline 9 & 2004 & Abuja - Nigéria* & Embaixada \\
\hline 10 & 2004 & Adis-Abeba - Etiópia* & Embaixada \\
\hline 11 & 2004 & Atlanta - EUA & Consulado-Geral \\
\hline 12 & 2004 & Porto Ayacucho - Venezuela & Vice-Consulado \\
\hline 13 & 2005 & Beirute - Líbano & Consulado-Geral \\
\hline 14 & 2005 & Belmopan - Belize & Embaixada \\
\hline 15 & 2005 & Cartum - Sudão & Embaixada \\
\hline 16 & 2005 & Colombo - Sri Lanka & Embaixada \\
\hline 17 & 2005 & Cotonou - Benin & Embaixada \\
\hline 18 & 2005 & Dar-es-Salaam - Tanzânia* & Embaixada \\
\hline 19 & 2005 & Doha - Catar & Embaixada \\
\hline 20 & 2005 & Genebra - Suíça & Consulado-Geral \\
\hline 21 & 2005 & Iaundê - Cameroun & Embaixada \\
\hline 22 & 2005 & Iquitos - Peru & Consulado \\
\hline 23 & 2005 & Lagos - Nigéria & Consulado-Geral \\
\hline 24 & 2005 & Lomé - Togo & Embaixada \\
\hline 25 & 2005 & Malabo - Guiné Equatorial & Embaixada \\
\hline 26 & 2005 & Nassau - Bahamas & Embaixada \\
\hline 27 & 2005 & Paris - França & Consulado-Geral \\
\hline 28 & 2005 & Zagreb - Croácia & Embaixada \\
\hline 29 & 2006 & Astana - Cazaquistão & Embaixada \\
\hline 30 & 2006 & Conacri - República da Guiné & Embaixada \\
\hline 31 & 2006 & Gaborone - Botsuana & Embaixada \\
\hline 32 & 2006 & Lusaca - Zâmbia & Embaixada \\
\hline 33 & 2006 & Madri - Espanha & Consulado-Geral \\
\hline 34 & 2006 & Mendoza - Argentina & Consulado-Geral \\
\hline 35 & 2006 & Mumbai - Índia & Consulado-Geral \\
\hline 36 & 2007 & Bamaco - Mali & Embaixada \\
\hline 37 & 2007 & Bratislava - Eslováquia & Embaixada \\
\hline 38 & 2007 & Brazzaville - Congo & Embaixada \\
\hline
\end{tabular}




\begin{tabular}{|c|c|c|c|}
\hline \# & $\begin{array}{c}\text { CRIAÇÃO/ } \\
\text { REABERTURA }\end{array}$ & POSTO & CATEGORIA \\
\hline 39 & 2007 & Castries - Santa Lúcia & Embaixada \\
\hline 40 & 2007 & Lethem - Guiana & Vice-Consulado \\
\hline 41 & 2007 & Liubliana - Eslovênia & Embaixada \\
\hline 42 & 2007 & Nuakchott - Mauritânia & Embaixada \\
\hline 43 & 2007 & Uagadugu - Burkina Faso & Embaixada \\
\hline 44 & 2007 & Vancouver - Canadá & Consulado-Geral \\
\hline 45 & 2008 & Baku - Azerbaijão & Embaixada \\
\hline 46 & 2008 & Basseterre - São Cristóvão e Névis & Embaixada \\
\hline 47 & 2008 & Caracas - Venezuela & Consulado-Geral \\
\hline 48 & 2008 & Hamamatsu - Japão & Consulado-Geral \\
\hline 49 & 2008 & Hartford - EUA & Consulado-Geral \\
\hline 50 & 2008 & Mascate - Omã & Embaixada \\
\hline 51 & 2008 & México - México & Consulado-Geral \\
\hline 52 & 2008 & Pyongyang - Rep. Dem. Pop. da Coreia & Embaixada \\
\hline 53 & 2008 & Saint George's - Granada & Embaixada \\
\hline 54 & 2008 & Washington - EUA & Consulado-Geral \\
\hline 55 & 2009 & Cantão - China & Consulado-Geral \\
\hline 56 & 2009 & Daca - Bangladesh* & Embaixada \\
\hline 57 & 2009 & Istambul - Turquia & Consulado-Geral \\
\hline 58 & 2009 & Kingstown - São Vicente e Granadinas & Embaixada \\
\hline 59 & 2009 & Roseau - Dominica & Embaixada \\
\hline 60 & 2009 & Saint John's - Antígua e Barbuda & Embaixada \\
\hline 61 & 2010 & Bruxelas - Bélgica & Consulado-Geral \\
\hline 62 & 2010 & Cabul - Afeganistão & Embaixada \\
\hline 63 & 2010 & Faro - Portugal & Consulado-Geral \\
\hline 64 & 2010 & Freetown - Serra Leoa & Embaixada \\
\hline 65 & 2010 & Katmandu - Nepal & Embaixada \\
\hline 66 & 2010 & Lilongue - Maláui & Embaixada \\
\hline 67 & 2010 & Minsk - Belarus & Embaixada \\
\hline 68 & 2010 & Monróvia - Libéria & Embaixada \\
\hline 69 & 2010 & Nicósia - Chipre & Embaixada \\
\hline 70 & 2010 & Saint George de l'Oyapock - Guiana Francesa & Consulado \\
\hline 71 & 2010 & Sarajevo - Bósnia e Herzegóvina & Embaixada \\
\hline 72 & 2010 & Talin - Estônia & Embaixada \\
\hline 73 & 2010 & Tbilisi - Georgia & Embaixada \\
\hline 74 & 2010 & Tirana - Albânia & Embaixada \\
\hline 75 & 2010 & Yangon - Myanmar & Embaixada \\
\hline
\end{tabular}

Fonte: MRE.

* Casos conhecidos de reabertura. 


\section{Apêndice B - Roteiro de entrevista}

1) Na sua opinião, o Brasil tem uma política migratória consolidada?

2) Como é definida a política migratória atual do Brasil?

3) Em sua opinião, quais os objetivos da política migratória brasileira? Quais deveriam ser?

4) Quais as principais críticas feitas atualmente em relação à política migratória brasileira?

5) Como descreveria a relação entre os órgãos do governo federal que formulam/executam a política migratória? Quais os pontos de concordância e discordância?

6) Como avalia o tratamento oferecido pelo Estado brasileiro aos imigrantes, aos refugiados, aos apátridas e aos brasileiros retornados?

7) Em sua opinião, a política externa possui alguma influência sobre a política migratória?

8) Caso positivo, em sua visão, quais as repercussões da política externa brasileira dos últimos 10 anos sobre a política migratória?

9) Em sua avaliação, qual a necessidade da revisão da atualização da legislação migratória?

10) Como opera o Conselho Nacional de Imigração? Qual a sua participação como representante do órgão no Conselho?

11) Como avalia a postura do Brasil em relação aos Direitos Humanos dos migrantes?

12) Por que o Brasil ainda não ratificou a Convenção das Nações Unidas sobre a Proteção dos Direitos de Todos os Trabalhadores Migrantes e dos Membros das suas Famílias, de 1990, assinada pelo Presidente Lula em 2009?

13) Como a reciprocidade é utilizada pelo Brasil como instrumento de barganha nas negociações internacionais relacionadas aos direitos dos migrantes?

14) Acredita que as migrações contribuem para o desenvolvimento brasileiro? Como?

15) Acredita que a proteção dos direitos humanos dos migrantes pode favorecer a imagem do Brasil no exterior?

16) Como avalia a política migratória brasileira em geral?

17) Há perspectiva de mudanças na legislação e na política migratória?

18) Há algo que gostaria de acrescentar ou informar? 
Apêndice C - Entrevistas realizadas

\begin{tabular}{|c|c|c|c|}
\hline Nome do entrevistado & Cargo & Órgão & Data da entrevista \\
\hline João Guilherme Granja & Diretor & DEEST/MJ & $02 / 07 / 2014$ \\
\hline Rodrigo do Amaral Souza & Diretor & DIJ/MRE & $29 / 07 / 2014$ \\
\hline Paulo Sérgio de Almeida & Presidente & CNIg/MTE & $18 / 08 / 2014$ \\
\hline José Luiz Povill de Souza & Coordenador-Geral & CGPI/DPF & $15 / 09 / 2014$ \\
\hline
\end{tabular}




\section{Apêndice D - Composição do Conselho Nacional de Imigração}

\begin{tabular}{|c|c|c|c|}
\hline Governo & $\begin{array}{c}\text { Representantes dos } \\
\text { trabalhadores }\end{array}$ & $\begin{array}{l}\text { Representantes dos } \\
\text { empregadores }\end{array}$ & $\begin{array}{c}\text { Representante da } \\
\text { comunidade científica } \\
\text { e tecnológica }\end{array}$ \\
\hline $\begin{array}{l}\text { Trabalho e Emprego } \\
\text { Justiça } \\
\text { Relações Exteriores } \\
\text { Agricultura e } \\
\text { Abastecimento } \\
\text { Ciência e Tecnologia } \\
\text { Desenvolvimento, } \\
\text { Indústria e Comércio } \\
\text { Exterior } \\
\text { Saúde } \\
\text { Educação }\end{array}$ & $\begin{array}{l}\text { Central dos } \\
\text { Trabalhadores e } \\
\text { Trabalhadoras do Brasil } \\
\text { - CTB } \\
\text { Central Única dos } \\
\text { Trabalhadores- CUT } \\
\text { Força Sindical - FS } \\
\text { União Geral dos } \\
\text { Trabalhadores - Ugt } \\
\text { Central Geral dos } \\
\text { Trabalhadores do Brasil } \\
\text { - CGTB }\end{array}$ & $\begin{array}{l}\text { Confederação nacional } \\
\text { da indústria - CNI } \\
\text { Confederação Nacional } \\
\text { do Comércio de bens, } \\
\text { Serviços e Turismo - } \\
\text { CNC } \\
\text { Confederação da } \\
\text { Agricultura e Pecuária } \\
\text { do Brasil - CNA } \\
\text { Confederação Nacional } \\
\text { do Transporte - CNT } \\
\text { Confederação Nacional } \\
\text { das Instituições } \\
\text { Financeiras - CNF }\end{array}$ & $\begin{array}{l}\text { Sociedade Brasileira } \\
\text { para o Progresso da } \\
\text { Ciência- SBPC }\end{array}$ \\
\hline
\end{tabular}

Observadores

- Advocacia Geral da União - AGU

- Agência Brasileira de Inteligência - ABIN

- Comissão Nacional para População e Desenvolvimento - CNPD

- Defensória Pública da União - DPU

- Departamento da Polícia Federal - DPF

- Instituto Migrações e Direitos Humanos - IMDH

- Organização Internacional do Trabalho - OIT

- Organização Internacional para as Migrações - OIM

- Secretaria de Políticas de Previdência Social - SPPS/MPS

- Secretaria de Políticas de Promoção da Igualdade Racial - SEPPIR/PR

- Secretaria de Políticas para as Mulheres da Presidência da República - SPM/PR

- Secretaria dos Direitos Humanos da Presidência da República - SDH/PR 


\section{Apêndice E - Excertos de Atas do Conselho Nacional de Imigração}

\section{Reunião Ordinária - 2009, 10/02/2009 (linhas 389-409)}

“O Conselheiro Luciano Pestana Barbosa (MJ) informou que, em 2005, foi feita a Resolução Recomendada 06, que recomendava o Acordo de Regularização Migratória entre Brasil e Bolívia e que foi atendido rapidamente. Sugeriu que fosse incluído o Chile também, com quem o Ministério das Relações Exteriores negociou durante todo o ano a bilateralização do Acordo de Residência, mas que ainda falta a sua finalização. Segundo o Conselheiro Ralph Peter Hendersen (MRE), o acordo com o Chile já foi assinado, mas ainda não foi levado adiante por falta de agenda para negociar o Acordo Operativo, que dá execução ao Acordo de bilaterização. Não é possível privilegiar a Bolívia frente ao Chile. A Resolução, se for aprovada, fará frente aos dois. Com a Bolívia, é preciso negociar um acordo bilateral, e posteriormente o Acordo Operativo. Até lá, se o Paraguai tiver feito a sua parte, ou se tiver saído a Lei da Anistia que foi proposta em novembro e que está parada na Casa Civil, o problema estará resolvido. O Presidente, Paulo Sérgio de Almeida, enfatizou que o CNIg fez uma moção favorável à anistia proposta pelo Ministério da Justiça; que, no Fórum Social Mundial, o Presidente Lula anunciou que tinha a intenção de fazer essa anistia; que o Ministro Tarso Genro anunciou que ela está sendo preparada e que o CNIg entende que essa é uma medida fundamental para o Brasil, uma medida que vai tirar da ilegalidade uma série de pessoas que residem aqui há muitos anos, que contribuem com o crescimento e o desenvolvimento da nossa nação, mas que estão na obscuridade porque não conseguem se legalizar. A última anistia já completou dez anos e nesse período o país mudou; já é hora de haver outra anistia."

\section{Reunião Ordinária - 2009, 17/11/2009 (linhas 75-84)}

"O Sr. Paulo Sérgio de Almeida lembrou sobre o Acordo de Residência para Nacionais dos Estados Partes do MERCOSUL, Bolívia e Chile, já em vigor, e questionou ao Sr. Ralph Henderson se estava efetivamente sendo aplicado. O Conselheiro Ralph disse que na Bolívia tudo é complicado, mas que no Paraguai houve uma reunião para definir estratégias e esclarecer dúvidas dos dois lados e que o Paraguai já estaria começando a distribuir uma cartilha específica. Informou que está planejado, para o mês de novembro, a realização de consulados itinerantes brasileiros especialmente em locais de concentração de brasileiros e ao mesmo tempo fazer o registro com o pessoal da Imigração do Paraguai, para os brasileiros serem documentados por meio do Acordo de Residência." 
Apêndice F - Número de deportações de 1995 a 2010 - por nacionalidade

\begin{tabular}{|c|c|c|c|c|c|c|c|c|c|c|c|c|}
\hline & Argentina & Bolívia & China & Espanha & EUA & Itália & Líbano & Peru & Portugal & Uruguai & Outros & Total \\
\hline 1995 & 9 & 3 & 9 & 0 & 8 & 5 & 52 & 7 & 2 & 4 & 67 & 166 \\
\hline 1996 & 11 & 2 & 11 & 1 & 5 & 2 & 24 & 13 & 2 & 4 & 71 & 146 \\
\hline 1997 & 14 & 4 & 7 & 2 & 4 & 4 & 20 & 12 & 4 & 9 & 57 & 137 \\
\hline 1998 & 20 & 2 & 15 & 2 & 4 & 4 & 34 & 10 & 3 & 3 & 54 & 151 \\
\hline 1999 & 11 & 4 & 8 & 0 & 1 & 4 & 5 & 8 & 4 & 8 & 50 & 103 \\
\hline 2000 & 12 & 6 & 9 & 1 & 0 & 4 & 3 & 29 & 0 & 7 & 36 & 107 \\
\hline 2001 & 7 & 21 & 0 & 0 & 2 & 6 & 1 & 20 & 6 & 14 & 71 & 148 \\
\hline 2002 & 15 & 197 & 17 & 1 & 1 & 4 & 3 & 21 & 2 & 11 & 68 & 340 \\
\hline 2003 & 14 & 87 & 9 & 3 & 5 & 9 & 3 & 32 & 8 & 15 & 58 & 243 \\
\hline 2004 & 3 & 4 & 1 & 3 & 0 & 2 & 0 & 7 & 2 & 3 & 13 & 38 \\
\hline 2005 & 17 & 189 & 50 & 8 & 6 & 22 & 8 & 55 & 10 & 20 & 161 & 546 \\
\hline 2006 & 6 & 30 & 13 & 6 & 1 & 8 & 3 & 31 & 3 & 15 & 73 & 189 \\
\hline 2007 & 1 & 22 & 12 & 6 & 4 & 13 & 10 & 26 & 5 & 8 & 82 & 189 \\
\hline 2008 & 3 & 45 & 23 & 11 & 7 & 12 & 4 & 30 & 11 & 15 & 114 & 275 \\
\hline 2009 & 2 & 36 & 14 & 14 & 5 & 12 & 5 & 25 & 14 & 3 & 87 & 217 \\
\hline 2010 & 4 & 44 & 1 & 3 & 9 & 11 & 0 & 13 & 6 & 8 & 109 & 208 \\
\hline Total & 149 & 696 & 199 & 61 & 62 & 122 & 175 & 339 & 82 & 147 & 1.171 & 3.203 \\
\hline$\%$ & $4,7 \%$ & $21,7 \%$ & $6,2 \%$ & $1,9 \%$ & $1,9 \%$ & $3,8 \%$ & $5,5 \%$ & $10,6 \%$ & $2,6 \%$ & $4,6 \%$ & $36,6 \%$ & $100,0 \%$ \\
\hline
\end{tabular}

Fonte: Departamento de Polícia Federal. 